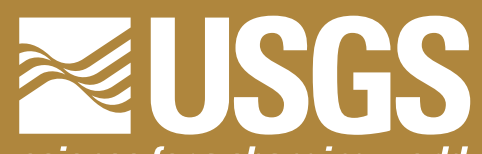

science for a changing world

\title{
Geochronologic, Isotopic, and Geochemical Data from Igneous Rocks in the Lane Mountain Area, San Bernardino County, California
}

Open-File Report 2019-1070 
Cover: Photograph of Late Cretaceous granodiorite outcrops in the Lane Mountain area, San Bernardino County, California. Locality of geochronology sample 15-LM-1076 for which a uranium-lead (U-Pb) zircon age of $84.7 \pm 0.9$ mega-annum (Ma) was obtained. U.S. Geological Survey photograph by Paul Stone. 


\section{Geochronologic, Isotopic, and Geochemical Data from Igneous Rocks in the Lane Mountain Area, San Bernardino County, California}

By Paul Stone, Howard J. Brown, M. Robinson Cecil, Robert J. Fleck, Jorge A. Vazquez, John A. Fitzpatrick, and José J. Rosario

Open-File Report 2019-1070 


\title{
U.S. Department of the Interior DAVID BERNHARDT, Secretary
}

\author{
U.S. Geological Survey \\ James F. Reilly II, Director
}

U.S. Geological Survey, Reston, Virginia: 2019

For more information on the USGS - the Federal source for science about the Earth, its natural and living resources, natural hazards, and the environment-visit https://www.usgs.gov or call 1-888-ASK-USGS.

For an overview of USGS information products, including maps, imagery, and publications, visit https://store.usgs.gov.

Any use of trade, firm, or product names is for descriptive purposes only and does not imply endorsement by the U.S. Government.

Although this information product, for the most part, is in the public domain, it also may contain copyrighted materials as noted in the text. Permission to reproduce copyrighted items must be secured from the copyright owner.

Suggested citation:

Stone, P., Brown, H.J., Cecil, M.R., Fleck, R.J., Vazquez, J.A., Fitzpatrick, J.A., and Rosario, J., 2019, Geochronologic, isotopic, and geochemical data from igneous rocks in the Lane Mountain area, San Bernardino County, California: U.S. Geological Survey Open-File Report 2019-1070, 34 p.,

https://doi.org/10.3133/ofr20191070.

ISSN 2331-1258 (online) 


\section{Contents}

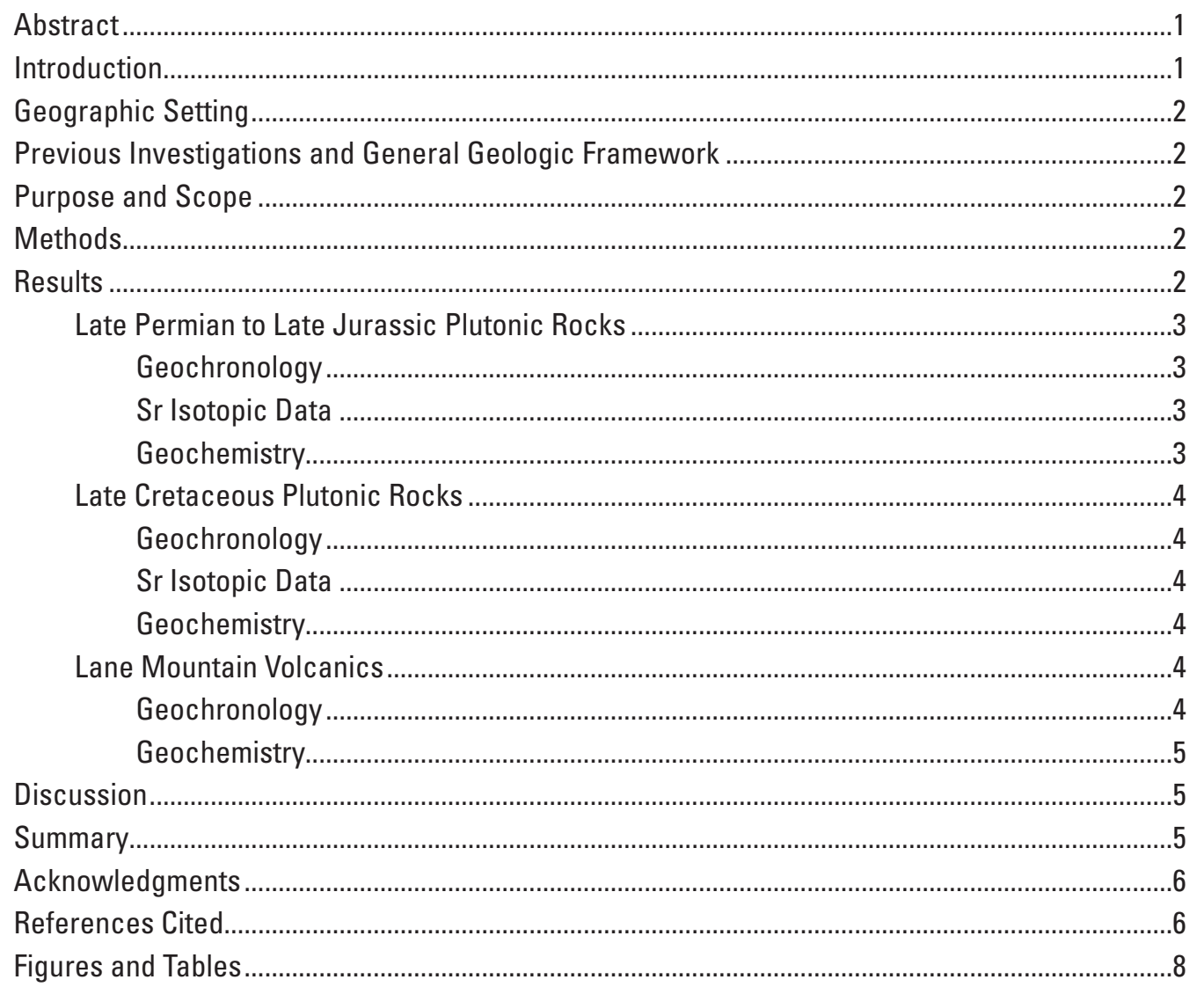




\section{Figures}

1. Map of the north-central Mojave Desert region showing outcrops of El Paso terrane and location of report area

2. Map showing the $\mathrm{Sr}_{\mathrm{i}}=0.706$ isopleth in California and Nevada...................................11

3. Map showing general geology of Lane Mountain area (modified from McCulloh, 1960) and locations of samples included in this report .......................................................12

4. Diagrams showing weighted mean SHRIMP-RG U-Pb zircon ages of samples 14-LM-1, 14-LM-43, 14-LM-64, 14-LM-154, 14-LM-490, and 15-LM-1076.

5. Diagrams showing weighted mean SHRIMP-RG U-Pb zircon ages of samples 15-LM1124, 16-LM-1301, 16-LM-1304, and HJB-3.

6. Diagram showing increase of $\mathrm{Sr}_{\mathrm{i}}$ with decreasing age of plutonic rock samples in the Lane Mountain area

7. Modified total alkali-silica (TAS) diagram showing the classification of samples included in this report

8. Diagram showing the aluminum saturation index for samples included in this report

9. Diagram showing the modified alkali-lime index for samples included in this report.

10. Diagram showing rare-earth element abundances normalized to chondrite values for samples included in this report

11. Diagram showing trace element abundances normalized to normal-mid-ocean ridgebasalt for samples included in this report.....................................................................16

12. Diagram showing $\mathrm{La}_{N} / \mathrm{Yb}_{\mathrm{N}} \mathrm{vs}$. $\mathrm{Yb}_{\mathrm{N}}$ for samples included in this report...........................17

13. Diagram showing $\mathrm{Sr} / \mathrm{Y}$ vs. $\mathrm{Y}$ for samples included in this report....................................17

14. Diagram showing Rb vs. $\mathrm{Y}+\mathrm{Nb}$ in samples included in this report...............................17

\section{Tables}

1. Location and basic lithologic, geochronologic, isotopic, and geochemical information for rock samples studied for this report.

2. Sample descriptions, Lane Mountain area, San Bernardino County, California .............19

3. SHRIMP-RG U-Pb zircon data for samples analyzed in this report,

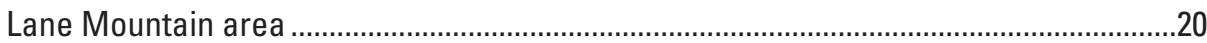

4. Rubidium-strontium isotopic data for the eight samples analyzed for this report ..........32

5. WDXRF (Wavelength dispersive X-ray fluorescence) geochemical analyses of samples studied for this report.

6. ICP-AES-MS (Inductively coupled plasma atomic emission spectroscopy-mass spectrometry) geochemical analyses of samples studied for this report. 


\section{Conversion Factors}

\begin{tabular}{lll}
\hline \multicolumn{1}{c}{ Multiply } & \multicolumn{1}{c}{ By } & \multicolumn{1}{c}{ To obtain } \\
\hline & Length & \\
\hline centimeter $(\mathrm{cm})$ & 0.3937 & inch (in.) \\
millimeter (mm) & 0.03937 & inch (in.) \\
meter (m) & 3.281 & foot (ft) \\
kilometer $(\mathrm{km})$ & 0.6214 & mile (mi) \\
meter $(\mathrm{m})$ & 1.094 & yard (yd) \\
\hline
\end{tabular}

\section{Datum}

Horizontal coordinate information is referenced to the North American Datum of 1927

(NAD27).

\section{Abbreviations}

\begin{tabular}{|c|c|}
\hline ASI & aluminum saturation index \\
\hline ICP-AES & $\begin{array}{l}\text { inductively coupled plasma atomic emission } \\
\text { spectroscopy-mass spectrometry }\end{array}$ \\
\hline LA-ICP-MS & $\begin{array}{l}\text { laser ablation-inductively coupled plasma- } \\
\text { mass spectrometry }\end{array}$ \\
\hline $\mathrm{Ma}$ & $\begin{array}{l}\text { mega-annum (a unit of time that refers to one } \\
\text { million years before present) }\end{array}$ \\
\hline MALI & modified alkali-lime index \\
\hline ppm & parts per million \\
\hline REE & rare-earth element \\
\hline SHRIMP-RG & $\begin{array}{l}\text { Sensitive High-Resolution Ion MicroProbe- } \\
\text { Reverse Geometry }\end{array}$ \\
\hline $\mathrm{Sr}_{\mathrm{i}}$ & initial ${ }^{87} \mathrm{Sr} /{ }^{86} \mathrm{Sr}$ ratio \\
\hline TAS & total alkali-silica \\
\hline TE & trace element \\
\hline TIMS & thermal ionization mass spectrometry \\
\hline WDXRF & wavelength dispersive X-ray fluorescence \\
\hline
\end{tabular}




\section{Chemical Symbols}

\begin{tabular}{|c|c|c|c|}
\hline $\mathrm{Ag}$ & Silver & Mo & Molybdenum \\
\hline $\mathrm{Al}$ & Aluminum & $\mathrm{Nb}$ & Niobium \\
\hline As & Arsenic & $\mathrm{Nd}$ & Neodymium \\
\hline B & Boron & $\mathrm{Ni}$ & Nickel \\
\hline $\mathrm{Ba}$ & Barium & $\mathrm{O}$ & Oxygen \\
\hline $\mathrm{Be}$ & Beryllium & $\mathrm{P}$ & Phosphorus \\
\hline $\mathrm{Bi}$ & Bismuth & $\mathrm{Pb}$ & Lead \\
\hline $\mathrm{Ca}$ & Calcium & $\mathrm{Pm}$ & Promethium \\
\hline $\mathrm{Cd}$ & Cadmium & $\operatorname{Pr}$ & Praseodymium \\
\hline $\mathrm{Ce}$ & Cerium & $\mathrm{Rb}$ & Rubidium \\
\hline Co & Cobalt & $\mathrm{S}$ & Sulfur \\
\hline $\mathrm{Cr}$ & Chromium & $\mathrm{Sb}$ & Antimony \\
\hline Cs & Cesium & $\mathrm{Sc}$ & Scandium \\
\hline $\mathrm{Cu}$ & Copper & $\mathrm{Si}$ & Silicon \\
\hline Dy & Dysprosium & $\mathrm{Sm}$ & Samarium \\
\hline $\mathrm{Er}$ & Erbium & $\mathrm{Sn}$ & Tin \\
\hline $\mathrm{Eu}$ & Europium & $\mathrm{Sr}$ & Strontium \\
\hline $\mathrm{Fe}$ & Iron & $\mathrm{Ta}$ & Tantalum \\
\hline $\mathrm{Ga}$ & Gallium & $\mathrm{Tb}$ & Terbium \\
\hline Gd & Gadolinium & Th & Thorium \\
\hline $\mathrm{Ge}$ & Germanium & $\mathrm{Ti}$ & Titanium \\
\hline Hf & Hafnium & $\mathrm{Tl}$ & Thallium \\
\hline Ho & Holmium & $\mathrm{Tm}$ & Thulium \\
\hline In & Indium & $\mathrm{U}$ & Uranium \\
\hline K & Potassium & $\mathrm{V}$ & Vanadium \\
\hline $\mathrm{La}$ & Lanthanum & $\mathrm{W}$ & Tungsten \\
\hline $\mathrm{Li}$ & Lithium & $\mathrm{Y}$ & Yttrium \\
\hline $\mathrm{Lu}$ & Lutetium & $\mathrm{Yb}$ & Ytterbium \\
\hline $\mathrm{Mg}$ & Magnesium & $\mathrm{Zn}$ & Zinc \\
\hline $\mathrm{Mn}$ & Manganese & $\mathrm{Zr}$ & Zirconium \\
\hline
\end{tabular}




\title{
Geochronologic, Isotopic, and Geochemical Data from Igneous Rocks in the Lane Mountain Area, San Bernardino County, California
}

\author{
By Paul Stone, ${ }^{1}$ Howard J. Brown, ${ }^{2}$ M. Robinson Cecil, ${ }^{3}$ Robert J. Fleck, ${ }^{1}$ Jorge A. Vazquez, ${ }^{1}$ \\ John A. Fitzpatrick, ${ }^{1}$ and José J. Rosario ${ }^{4}$
}

\begin{abstract}
We present new geochronologic, isotopic, and geochemical data for selected igneous rocks in the Lane Mountain area, California. We determined SHRIMP-RG U-Pb zircon ages for the following units: (1) Larrea complex ( $253 \mathrm{Ma}$ and 149-146 Ma); (2) Daisy granodiorite ( 151 Ma); (3) Jack Spring quartz monzonite ( $\sim 85-82 \mathrm{Ma})$; (4) unnamed porphyritic dikes and stocks ( $\sim 80-73 \mathrm{Ma}$ ); and (5) Lane Mountain volcanics $(\sim 22 \mathrm{Ma})$. These results confirm and refine previous age determinations for the Larrea complex, Jack Spring quartz monzonite, and Lane Mountain volcanics, and provide the first reliable ages for the Daisy granodiorite and the unnamed porphyritic rocks. $\mathrm{Sr}_{i}$ of the plutonic rocks increases from $\sim 0.704$ to $\sim 0.705-0.706$ to $\sim 0.708-0.709$ for samples dated as $\sim 250, \sim 150$, and $\sim 85-70 \mathrm{Ma}$, respectively, which indicates progressively greater involvement of Precambrian continental lithosphere in magma generation through time. $\mathrm{The} \mathrm{Sr}_{\mathrm{i}}$ and geochemical data suggest that the most significant change in magmatic source occurred between $\sim 150$ and $85 \mathrm{Ma}$.
\end{abstract}

\section{Introduction}

The Lane Mountain area is in the north-central Mojave Desert about 20 kilometers $(\mathrm{km})$ northeast of Barstow, California (fig. 1), a region of complex and incompletely understood

\footnotetext{
${ }^{1}$ U.S. Geological Survey

${ }^{2}$ Apple Valley, Calif.

${ }^{3}$ California State University Northridge

${ }^{4}$ California State University East Bay
}

geology. In this region, metasedimentary and metavolcanic rocks of offshore (eugeoclinal) lithologic character (McCulloh, 1952, 1960; Carr and others, 1997) are associated with a variety of plutonic rocks, some of which are characterized by initial ${ }^{87} \mathrm{Sr} r{ }^{86} \mathrm{Sr}\left(\mathrm{Sr}_{\mathrm{i}}\right)$ values $<0.706$ and other isotopic signatures that indicate little or no Precambrian continental (sialic) lithosphere in their magmatic sources (Kistler, 1990; Miller and others, 1995). The metasedimentary and metavolcanic rocks constitute the El Paso terrane of Silberling and others $(1987,1992)$ (fig. 1), which many geologists have interpreted as allochthonous because of its apparent juxtaposition against Paleozoic and early Mesozoic continental shelf deposits to the east (for example, Burchfiel and Davis, 1981; Miller and others, 1995). The associated low-Sr ${ }_{i}$ plutonic rocks form a narrow, northwest trending belt that is surrounded by plutonic rocks with $\mathrm{Sr}_{\mathrm{i}}>0.706$ and is bisected and offset by the late Cenozoic, left-lateral Garlock Fault (Kistler and Ross, 1990) (fig. 2). The tectonic significance of the El Paso terrane and the associated low-Sr $r_{i}$ plutonic belt has been much debated but remains unresolved.

To address this gap in understanding, we are conducting a multifaceted investigation of the Lane Mountain area that includes detailed geologic mapping, uranium-lead (U-Pb) zircon geochronology, strontium isotopic analysis, and geochemical analysis. Preliminary results of this investigation, focused primarily on the geologic mapping, have been presented elsewhere (Brown, 2016a, 2016b; Brown and others, 2016, 2018). In this report, we present geochronologic, isotopic, and geochemical data from 10 samples of igneous rocks that were collected and analyzed in support of geologic mapping activities from 2014 to 2016. These data build on previous analytical studies in the Lane Mountain area and strengthen the basis for interpreting the local and regional geologic framework and history. 


\section{Geographic Setting}

The report area includes parts of the Lane Mountain, Williams Well, Paradise Range, and Coyote Lake 7.5' quadrangles, which together supersede the older Lane Mountain 15, quadrangle. The area (fig. 3) encompasses bedrock uplands that extend northward and southeastward from Lane Mountain, including the northern part of the Calico Mountains. These uplands drain eastward and northward into a broad, alluvial valley that includes Coyote Lake, which is about $2 \mathrm{~km}$ east of the report area. Access to the area is provided by Fort Irwin Road (fig. 3) and a network of unpaved roads shown on the topographic quadrangle maps.

\section{Previous Investigations and General Geologic Framework}

The geology of the Lane Mountain 15' quadrangle was mapped by McCulloh $(1952,1960)$, who distinguished numerous units of (1) pre-Tertiary metamorphic and plutonic rocks and (2) Tertiary volcanic and sedimentary rocks. Later analytical work added geochronologic, isotopic, and geochemical data that have refined the framework of both the pre-Tertiary and Tertiary rocks (Kistler and Peterman, 1978; Burke and others, 1982; Miller and Sutter, 1982; Miller and Glazner, 1995; Miller and others, 1995; Singleton and Gans, 2008). A modified version of the map of McCulloh (1960) was published by Dibblee (2008).

Figure 3 presents a simplified version of McCulloh's (1960) mapping with updated age information (Brown and others, 2018; this report). Four major lithologic assemblages are shown: (1) metamorphosed and deformed sedimentary and volcanic rocks of Paleozoic and Mesozoic age; (2) mostly mafic- to intermediate-composition plutonic rocks of late Permian to Late Jurassic age; (3) felsic plutonic rocks of late Cretaceous age; and (4) Tertiary volcanic and sedimentary rocks, including the Jackhammer and Pickhandle Formations of McCulloh $(1952,1960)$, that unconformably overlie the older assemblages. Although the metamorphic rocks are intruded by both groups of plutonic rocks, some are demonstrably younger than the oldest rocks in the late Permian to Late Jurassic plutonic assemblage (Brown and others, 2018). This relation complicates the geologic framework and indicates a complex, intertwined history of pre-Tertiary sedimentation, magmatism, metamorphism, and deformation.

\section{Purpose and Scope}

The primary purpose of this study was to determine Sensitive High-Resolution Ion MicroProbe-Reverse Geometry (SHRIMP-RG) U-Pb zircon ages for selected igneous rock units in the Lane Mountain area. Because most of these units had been previously dated using other methods, a specific goal was to test and refine the existing ages. Ten samples (table 1) from both major plutonic suites (fig. 3, units JPp and Kp) and the Tertiary Lane Mountain volcanics of McCulloh (1952, 1960) (fig. 3, part of unit Tvs) were dated. In addition, wholerock geochemical analyses were obtained for all 10 samples, and whole-rock rubidium-strontium ( $\mathrm{Rb}-\mathrm{Sr}$ ) isotopic data were obtained for 8 . These ages and analytical data provide a basis for reevaluating and, where necessary, revising the map units of McCulloh (1960).

\section{Methods}

U-Pb zircon analyses were carried out on the U.S. Geological Survey (USGS) SHRIMP-RG ion microprobe at Stanford University. Zircon crystals were separated from $\sim 1-2$-kilogram $(\mathrm{kg})$ samples using standard processing techniques. Individual zircons from mineral separates were mounted in epoxy, polished, and coated with gold prior to analysis. Cathodoluminescence (CL) images were used to select relatively homogeneous spots within compositionally zoned zircons. Most zircons were analyzed at a single spot near the crystal rim, but some were also analyzed at a second spot in the interior area of the crystal. Analytical data reduction utilized the software programs Squid 2 version 2.51 and Isoplot version 3.76 (Ludwig, 2009, 2012), which calculated trace element concentrations and determined the weighted mean crystallization age of coherent groups of zircon spot analyses for each sample. Trace element concentrations were calibrated to MAD-559 zircon standard (Coble and others, 2018).

Determinations of $\mathrm{Sr}_{\mathrm{i}}$ involved three steps. First, the isotopic ratio of ${ }^{87} \mathrm{Sr} /{ }^{86} \mathrm{Sr}$ for each powdered sample was measured on a Finnigan MAT 261 solid source mass spectrometer at the USGS in Menlo Park, California, with methods consistent with those reported by Bayless and others (2004). That ratio and the $\mathrm{Rb}$ and $\mathrm{Sr}$ concentrations determined by inductively coupled plasma atomic emission spectroscopy-mass spectrometry (ICPAES-MS) geochemical analysis (see below) were then used to calculate the ${ }^{87} \mathrm{Rb} /{ }^{86} \mathrm{Sr}$ isotopic ratio. Finally, both isotopic ratios and the $\mathrm{U}-\mathrm{Pb}$ zircon age of the sample were used to calculate the $\mathrm{Sr}_{\mathrm{i}}$.

Whole-rock geochemical analyses were performed under contract to the USGS using wavelength dispersive X-ray fluorescence (WDXRF) and ICP-AES-MS. We used the commercial software program IgPet by RockWare ${ }^{\mathbb{B}}$ to create graphic displays of the geochemical data.

\section{Results}

Table 1 lists the samples studied for this report and gives the principle analytical results for each. Table 2 provides lithologic descriptions, and figure 3 shows the mapped sample localities. Table 3 presents zircon U-Pb and trace element data, and figures 4 and 5 show weighted mean zircon ages for 
each sample. Table 4 presents $\mathrm{Rb}-\mathrm{Sr}$ isotopic data and figure 6 shows the relation between $\mathrm{Sr}_{i}$ and sample age. Tables 5 and 6 present WDXRF and ICP-AES geochemical analyses, respectively, and figures 7-14 illustrate various geochemical parameters that help characterize and differentiate the sampled rocks. The WDXRF data were used to produce total alkalisilica (TAS), aluminum saturation index (ASI), and modified alkali-lime index (MALI) plots (figs. 7-9); the ICP-AES data were used to produce spider plots of rare-earth and trace elements (REE and TE) (figs. 10,11) and selected discrimination diagrams (figs. 12-14). The analytical results are summarized below.

\section{Late Permian to Late Jurassic Plutonic Rocks}

\section{Geochronology}

McCulloh (1960) mapped a widespread unit of dioritic and gabbroic plutonic rocks of presumed Mesozoic age as the informally named Larrea complex (most of unit JPp on fig. 3). Miller and Sutter (1982) determined a Late Jurassic crystallization age of $\sim 148$ mega-annum (Ma) for rocks in the eastern part of the Larrea complex from ${ }^{40} \mathrm{Ar}^{39} \mathrm{Ar}$ data on hornblende. By contrast, Miller and others (1995) obtained an early Middle Triassic U-Pb zircon crystallization age of $\sim 240$ Ma for rocks in the western part of the Larrea complex (their Lane Mountain diorite) using multicrystalline thermal ionization mass spectrometry (TIMS). The significance of this nearly 100 million-year difference in age has not been addressed by previous work.

We obtained ages from three zircon samples of the Larrea complex in our study area to test these earlier results (fig. 3). Sample 14-LM-43 is quartz diorite from the western part of the Larrea complex near the sample of Miller and others (1995); samples 14-LM-154 and 14-LM-490 are gabbro and quartz diorite, respectively, from the eastern part of the Larrea complex within the area studied by Miller and Sutter (1982). We also obtained ages using a more felsic sample, 14-LM-1, from the Daisy granodiorite of McCulloh (1960), which is spatially associated with the eastern part of the Larrea complex (and is part of unit JPp on figure 3).

Our sample 14-LM-43 yielded a weighted mean age of $252.8 \pm 1.9 \mathrm{Ma}$ (fig. 4), which is close to the currently accepted Permian-Triassic boundary age of $\sim 252.2 \mathrm{Ma}$ (Gradstein and others, 2012) and is in approximate agreement with the younger $\sim 240$ Ma TIMS age reported by Miller and others (1995). By contrast, our other three samples yielded Late Jurassic ages close to the $\sim 148 \mathrm{Ma}$ age reported by Miller and Sutter (1982). From oldest to youngest, samples 14-LM-1, 14-LM-490, and 14-LM-154 yielded weighted mean ages of $150.7 \pm 3.0,148.9 \pm 2.6$, and $146.0 \pm 3.8$ Ma respectively (fig. 4). These results confirm that the Larrea complex contains rocks of two very different ages and likely is a composite unit. In addition, the data show that the Daisy granodiorite is approximately coeval with the Late Jurassic rocks of the Larrea complex. A similar dataset was recently published by Cecil and others (2019), who determined U-Pb zircon ages of $\sim 253$ and $\sim 149 \mathrm{Ma}$, respectively, for a quartz diorite pluton and a quartz monzonite pluton about $4 \mathrm{~km}$ west of the present study area using individual-crystal laser ablation-inductively coupled plasma-mass spectrometry (LA-ICP-MS).

\section{Sr Isotopic Data}

Miller and others (1995) determined $\mathrm{Sr}_{\mathrm{i}}=0.70370$ from their $\sim 240$ Ma dated sample and $\mathrm{Sr}_{\mathrm{i}}=0.70400$ and 0.70419 from two other nearby samples presumed to be of about the same age. These low $\mathrm{Sr}_{\mathrm{i}}$ values, together with neodymium $(\mathrm{Nd})$ and $\mathrm{Pb}$ isotopic data from the same samples, indicated "limited continental crust involvement" (Miller and others, 1995) in the source of the sampled plutonic rocks. Our late Permian-Early Triassic sample 14-LM-43 yielded $\mathrm{Sr}_{\mathrm{i}}=$ 0.70396 (fig. 6), very similar to the results of Miller and others (1995).

By contrast, Miller and Glazner (1994) determined $\mathrm{Sr}_{\mathrm{i}}$ values between 0.7050 and 0.7063 for several plutonic rock samples of presumed Late Jurassic age in and near the Lane Mountain area. These $\mathrm{Sr}_{\mathrm{i}}$ values, together with $\mathrm{Nd}$ isotopic data from the same samples, indicated greater involvement of Precambrian continental lithosphere in the generation of these magmas than those of the older rocks. $\mathrm{Sr}_{i}$ values from our Late Jurassic samples 14-LM-1, 14-LM-154, and 14-LM$490(0.70590,0.70553$, and 0.70511 , respectively; fig. 6) are consistent with the results of Miller and Glazner (1995).

\section{Geochemistry}

TAS, ASI, and MALI plots (figs. 7-9) show that our late Permian-Early Triassic sample 14-LM-43 is dioritic, metaluminous, and calc-alkalic. On the same plots, Late Jurassic samples 14-LM-154, 14-LM-490, and 14-LM-1 range from gabbroic to granodioritic, from metaluminous to weakly peraluminous, and from calcic to calc-alkalic, respectively. Similar major-element geochemical compositions for rocks of the same age groups were reported by Miller and others (1995) and Miller and Glazner (1995).

Our other plots (figs. 10-14) further illustrate the generally similar geochemical properties of all four of our late Permian to Late Jurassic plutonic rock samples. All four samples show similar REE and TE spider plot patterns (figs. $10,11)$, with a negative niobium $(\mathrm{Nb})$ anomaly and positive potassium $(\mathrm{K})$ and $\mathrm{Pb}$ anomalies on the TE plot. All four samples also have $\mathrm{Yb}_{\mathrm{N}}>9$ and $\mathrm{La}_{\mathrm{N}} / \mathrm{Yb}_{\mathrm{N}}<12$ (fig. 12) and $\mathrm{Y}>$ 16 parts per million (ppm) and $\mathrm{Sr} / \mathrm{Y}<30$ (fig. 13). Finally, the four samples form a linear array near the right-hand boundary of the VAG (volcanic arc granites) field of the $\mathrm{Rb}$ vs. $(\mathrm{Y}+\mathrm{Nb})$ diagram (fig. 14). Of the four samples, the Late Jurassic gabbro (14-LM-154) is the most chemically distinct. 
Geochronologic, Isotopic, and Geochemical Data from Igneous Rocks in the Lane Mountain Area, California

\section{Late Cretaceous Plutonic Rocks}

\section{Geochronology}

McCulloh (1960) mapped two large bodies of light-gray, felsic plutonic rocks as the informally named Jack Spring quartz monzonite, one in the southwestern part of the present study area and one in the northeastern part (Kp on fig. 3). McCulloh $(1952,1960)$ tentatively considered this unit to be of Mesozoic age and noted that it intruded rocks of the Larrea complex and Daisy granodiorite. Miller and Sutter (1982) inferred a Late Cretaceous age of intrusion for the northeastern body based on an average ${ }^{40} \mathrm{Ar}-{ }^{39} \mathrm{Ar}$ mica (biotite and muscovite) cooling age of $\sim 78.4 \mathrm{Ma}$.

To test this result, we obtained ages from two zircon samples of Jack Spring quartz monzonite, one from each plutonic body in the study area (fig. 3). Sample 14-LM-64 from the northeastern body yielded a weighted mean age of 81.6 $\pm 1.7 \mathrm{Ma}$, and sample 15-LM-1076 from the southwestern body yielded a weighted mean age of $84.7 \pm 1.3 \mathrm{Ma}$ (fig. 4), consistent with the Late Cretaceous cooling age of Miller and Sutter (1982).

McCulloh $(1952,1960)$ also mapped a unit of "quartz latite porphyry dikes" that he recognized as younger than the other plutonic rocks in the area and to which he assigned an early Tertiary(?) age. We obtained ages from three zircon samples of this previously undated unit. Sample 15-LM-1124 is from a dike mapped by McCulloh (1960) near the northeast boundary of our study area, where it intrudes the Larrea complex; sample 16-LM-1301 is from a dike (not mapped by McCulloh) that cuts the northeastern body of the Jack Spring quartz monzonite; and sample HJB-3 is from a relatively large stock (not mapped by McCulloh) that intrudes metasedimentary rocks near the south margin of our study area (fig. 3 ). These samples yielded weighted mean ages of $77.3 \pm 1.6$, $\sim 79.7 \pm 1.5$, and $\sim 72.4 \pm 1.9 \mathrm{Ma}$, respectively and indicate a Late Cretaceous, not an early Tertiary age (fig. 5). Notably, all these samples contained a substantial number of older, inherited zircons that were excluded from the age determinations. The inherited zircons included slightly older Late Cretaceous grains, Late Jurassic to Early Cretaceous grains, and a few Precambrian grains as old as $\sim 1600 \mathrm{Ma}$ (table 3).

\section{Sr Isotopic Data}

We determined $\mathrm{Sr}_{\mathrm{i}}$ values of 0.70877 and 0.70809 for pluton samples 14-LM-64 and 15-LM-1076 and slightly higher values of 0.70976 and 0.70985 for porphyry samples 16-LM-1301 and HJB-3, respectively (fig. 6). These values are well above the $\mathrm{Sr}_{\mathrm{i}}=0.706$ isopleth value of Kistler (1990) and indicate substantial involvement of Precambrian continental lithosphere in the generation of these magmas in contrast to the lower $\mathrm{Sr}_{\mathrm{i}}$ values of the older rocks.

\section{Geochemistry}

Our five Late Cretaceous samples are all chemically similar and range from granodioritic to granitic, from weakly metaluminous to weakly peraluminous, and from weakly calcic to calc-alkalic (figs. 7-9). On figures 7-9, the Late Cretaceous samples cluster with the most felsic Late Jurassic sample 14-LM-1 (Daisy granodiorite). On the other plots (figs. 10-14), however, the Late Cretaceous samples, as a group, are readily distinguished from all the older samples. For example, the Late Cretaceous samples have a steeper REE profile (fig. 10) and a somewhat different TE profile (fig. 11) than the older samples, with lower titanium-lutetium ( $\mathrm{Ti}-\mathrm{Lu}$ ) and slightly stronger $\mathrm{Nb}, \mathrm{K}, \mathrm{Pb}$, and phosphorus $(\mathrm{P})$ anomalies. The Late Cretaceous samples also differ from the older samples in having $\mathrm{Yb}_{\mathrm{N}}<6$ and $\mathrm{La}_{\mathrm{N}} / \mathrm{Yb}_{\mathrm{N}}>24$ (fig. 12) and $\mathrm{Y}<12$ and $\mathrm{Sr} / \mathrm{Y}>50$ (fig. 13). Finally, the Late Cretaceous samples plot to the left of the older samples in the VAG (volcanic arc granites) field of the $\mathrm{Rb}$ vs. ( $\mathrm{Y}+\mathrm{Nb}$ ) diagram (fig. 14). At the same time, Late Cretaceous pluton samples 14-LM-1 and 15-LM-1076 are quite distinct from each other on all the plots, suggesting that they could represent separate intrusive bodies of slightly different age.

\section{Lane Mountain Volcanics}

\section{Geochronology}

McCulloh $(1952,1960)$ informally named the Lane Mountain volcanics to include a variety of volcanic rocks that he considered to be of Pliocene(?) age because they appeared to overlie a broad erosional surface that he interpreted to be post-Miocene. This unit includes a prominent sequence of felsic volcanic rocks that form the upper slopes and summit area of Lane Mountain itself. As mapped by McCulloh (1952, 1960), this sequence consists of a basal unit of conglomerate and white tuffaceous rocks $\sim 30$ meters (m) thick, an overlying unit of black vitrophyre $\sim 10 \mathrm{~m}$ thick, and a massive unit of volcanic rocks $\sim 150 \mathrm{~m}$ thick (with the top eroded) that he described as latite flows. Burke and others (1982) determined a sanidine K-Ar age of $\sim 23.1 \pm 0.2 \mathrm{Ma}$ for a sample near the base of the massive latite unit of McCulloh $(1952,1960)$, indicating that this unit was much older (late Oligocene or early Miocene) than previously suspected.

To test this age, we obtained an age from a zircon sample of volcanic rocks a few meters above the top of the black vitrophyre layer on the west side of Lane Mountain, near the sample locality of Burke and others (1982). Our sample (16-LM-1304) yielded a weighted mean age of $22.3 \pm 0.3 \mathrm{Ma}$, which is slightly younger than the previously determined age and indicates that this unit is early Miocene. 


\section{Geochemistry}

WDXRF analysis shows that sample 16-LM-1304 is rhyolitic, weakly peraluminous, and calc-alkalic (figs. 7-9). On the REE spider plot (fig. 10), this sample has a pattern similar to late Permian to Late Jurassic plutons, but with slightly higher gadolinium-lutetium $(\mathrm{Gd}-\mathrm{Lu})$ and a sharp negative Eu anomaly. The TE spider plot pattern (fig. 11) also resembles that of the late Permian to Late Jurassic plutons, but with prominent negative $\mathrm{P}$ and Ti anomalies and very high $\mathrm{Cs}$ and $\mathrm{Rb}$. Finally, sample 16-LM-1304 also plots in close association with the late Permian to Late Jurassic plutons on discrimination diagrams (figs. 12-14). These similarities are somewhat surprising given the differences in age and majorelement composition between the rhyolite and these plutonic rocks but suggest that the rhyolite could have been melted from rocks similar to the Larrea complex.

\section{Discussion}

The data presented in this report clarify several aspects of the bedrock geology and geochronology of the Lane Mountain area. The Larrea complex of McCulloh (1960) contains rocks of both late Permian-Early Triassic and Late Jurassic ages that presumably represent two separate intrusive events. In addition, the Daisy granodiorite of McCulloh (1960) likely represents a relatively felsic end member of the Late Jurassic part of the Larrea complex. The close similarity of our Late Jurassic U-Pb zircon ages to the $\sim 148 \mathrm{Ma}^{40} \mathrm{Ar}^{-39} \mathrm{Ar}$ hornblende age of Miller and Sutter (1982) suggests rapid cooling and (or) shallow emplacement of these plutonic rocks. The Jack Spring quartz monzonite of McCulloh (1960) is confirmed as Late Cretaceous and may consist of two separate intrusive bodies of slightly different age and chemical composition. Porphyritic dikes questionably assigned an early Tertiary age by McCulloh $(1952,1960)$ are Late Cretaceous, only slightly younger than the Jack Spring quartz monzonite. Finally, felsic volcanic rocks at Lane Mountain are confirmed as early Miocene.

These data highlight the need for new geologic mapping in the Lane Mountain area. For example, it is necessary to define and delineate a contact between the late Permian-Early Triassic and Late Jurassic parts of the Larrea complex, especially because some of the associated metasedimentary rocks are younger than the oldest plutonic rocks as noted earlier. Another mapping issue involves correlation of the $\sim 22.3 \mathrm{Ma}$ rhyolite of Lane Mountain, which is demonstrably older than the 19 Ma Pickhandle Formation (Singleton and Gans, 2008) but is not exposed in stratigraphic sequence beneath that unit. Our preliminary mapping (Brown and others, 2018) suggests that the $\sim 22.3$ Ma rhyolite may be a local volcanic flow correlative with the upper part of the Jackhammer Formation, which underlies the Pickhandle Formation.

The progressive increase in $\mathrm{Sr}_{i}$ values determined for plutonic rocks of decreasing age in the study area (fig. 6) indicates increasing involvement of Precambrian continental lithosphere in the generation of magmas through time, which suggests a complex magmatic and/or tectonic history. The following are possible explanations for the increase of $\mathrm{Sr}_{\mathrm{i}}$ : (1) the successive magmas tapped increasingly older or more differentiated parts of a static lithosphere, (2) the lithosphere was changing, with the crust perhaps thickening, between magmatic episodes, or (3) the older plutons originated in oceanic and/or transitional lithosphere and were tectonically emplaced above the continental lithosphere prior to the Late Cretaceous magmatic episode, akin to the interpretation of Miller and others (1995). In any case, this study shows that the low-Sr belt in the Lane Mountain area (fig. 2) is defined only by plutonic rocks of late Permian to Late Jurassic age and does not involve the Late Cretaceous rocks.

The late Permian-Early Triassic and Late Jurassic plutonic rocks of this study are chemically similar and could have originated in a similar, relatively primitive lithospheric environment, with the higher $\mathrm{Sr}_{\mathrm{i}}$ of the Late Jurassic plutons possibly reflecting assimilation of continent-derived sedimentary rocks (Miller and Glazner, 1995). The Late Cretaceous plutonic rocks, by contrast, are chemically distinct from the older plutons and seem to have originated in thick Precambrian continental lithosphere based on their high $\mathrm{Sr}_{\mathrm{i}}$ values. The biggest change in magmatic source, whatever the underlying cause, thus appears to have taken place between $\sim 150$ and $\sim 85 \mathrm{Ma}$. More detailed geochronologic, geochemical, and isotopic studies of all these plutonic rocks are needed to better understand their magmatic and tectonic significance.

\section{Summary}

Igneous rocks in the Lane Mountain area consist of the Larrea complex, Daisy granodiorite, Jack Spring quartz monzonite, unnamed porphyritic dikes and stocks, and the Lane Mountain volcanics (McCulloh, 1952, 1960). The new geochronologic, isotopic, and geochemical data presented here serve to better characterize these rocks and test previous determinations of their ages. SHRIMP-RG U-Pb dating of zircons shows that (1) the Larrea complex is a composite unit containing rocks of late Permian-Early Triassic ( $253 \mathrm{Ma})$ and Late Jurassic ( 149-146 Ma) age; (2) the Daisy granodiorite is Late Jurassic ( 151 Ma); (3) the Jack Spring quartz monzonite and the unnamed porphyry dikes are Late Cretaceous ( $\sim 85-82 \mathrm{Ma}$ and $\sim 80-73 \mathrm{Ma}$, respectively); and (4) rhyolite of the Lane Mountain volcanics is early Miocene $(\sim 22$ Ma). $\mathrm{Sr}$ isotope analysis shows that $\mathrm{Sr}_{\mathrm{i}}$ in the plutonic rocks increases from $\sim 0.704$ for samples of late Permian-Early Triassic age, to $\sim 0.705-0.706$ for samples of Late Jurassic age, to $\sim 0.708-0.710$ for samples of Late Cretaceous age. This increase indicates progressively greater involvement of Precambrian continental lithosphere in magma generation through time. Geochemical data suggest that the greatest change in magmatic source occurred between the Late Jurassic and Late Cretaceous, although the underlying cause of this change is unresolved. 


\section{Acknowledgments}

This work was funded by the USGS National Cooperative Geologic Mapping Program and was conducted under the project leadership of D.M. Miller. Juliet Ryan-Davis provided invaluable guidance and support as manager of the USGS mineral separation laboratory in Menlo Park. Zenon Valin digitized the geologic map of McCulloh (1960) for use in figure 3 .

\section{References Cited}

Bayless, E.R., Bullen, T.D., and Fitzpatrick, J.A., 2004, Use of ${ }^{87} \mathrm{Sr} /{ }^{86} \mathrm{Sr}$ and $\mathrm{d} 11 \mathrm{~B}$ to identify slag-affected sediment in southern Lake Michigan: Environmental Science and Technology, v. 38, p. 1330-1337.

Brown, H.J., 2016a, Detailed geologic map of the northern Calico Mountains and the Lane Mountain area, central Mojave Desert, California; part 1, the need for new mapping [abs.]: Geological Society of America Abstracts with Programs, v. 48, no. 4, https://doi.org/10.1130/ abs/2016CD-271692.

Brown, H.J., 2016b, Detailed geologic map of the northern Calico Mountains and the Lane Mountain area, central Mojave Desert, California; part 2, stratigraphy and structure of Paleozoic, Mesozoic, and Cenozoic rocks [abs.]: Geological Society of America Abstracts with Programs, v. 48, no. 4, https://doi.org/10.1130/abs/2016CD-271693.

Brown, H.J., Stone, P., Rosario, J., and Fitzpatrick, J., 2016, Detailed geologic map of the northern Calico Mountains and the Lane Mountain area, central Mojave Desert, California; part 3, preliminary digital geologic map [abs.]: Geological Society of America Abstracts with Programs, v. 48, no. 4, https://doi.org/10.1130/abs/2016CD-271694.

Brown, H.J., Stone, P., Cecil, M.R., and Fitzpatrick, J., 2018, New insights into the geology of the Lane Mountain and north Calico Mountains area, central Mojave Desert, California [abs.]: Geological Society of America Abstracts with Programs, v. 50, no. 5, https://doi.org/10.1130/ abs/2018RM-311369.

Burchfiel, B.C., and Davis, G.A., 1981, Mojave Desert and environs, chap. 9 of Ernst, W.G., ed., The geotectonic development of California, Rubey Volume 1: Englewood Cliffs, N.J., Prentice-Hall, p. 217-252.

Burke, D.B., Hillhouse, J.W., McKee, E.H., Miller, S.T., and Morton, J.L., 1982, Cenozoic rocks in the Barstow area of southern California - Stratigraphic relations, radiometric ages, and paleomagnetism: U.S. Geological Survey Bulletin 1529-E, p. E1-E16.
Carr, M.D., Christiansen, R.L., Poole, F.G., and Goodge, J.W., 1997, Bedrock geologic map of the El Paso Mountains in the Garlock and El Paso Peaks 7-1/2' quadrangles, Kern County, California: U.S. Geological Survey Miscellaneous Investigations Series Map I-2389, scale 1:24,000, 9 p.

Cecil, M.R., Ferrer, M.A., Riggs, N.R., Marsaglia, K., Kylander-Clark, A., Ducea, M.N., and Stone, P., 2019, Early arc development recorded in Permian-Triassic plutons of the northern Mojave Desert region, California, USA: Geological Society of America Bulletin, v. 131, nos. 5-6, p. 749-765.

Coble, M.A., Vazquez, J.A., Barth, A.P., Wooden, J., Burns, D., Kylander-Clark, A., Jackson, S., and Vennari, C.E., 2018, Trace element characterisation of MAD-559 zircon reference material for ion microprobe analysis: Geostandards and Geoanalytical Research, v. 42, no. 4, p. 481-497.

Dibblee, T.W., Jr., 2008, Geologic map of the Opal Mountain and Lane Mountain 15-minute quadrangles, San Bernardino County, California: Santa Barbara, Calif., Dibblee Geology Center Map DF-403, scale 1:62,500.

Frost, B.R., Barnes, C.G., Collins, W.J., Arculus, R.J., Ellis, D.J., and Frost, C.D., 2001, A geochemical classification for granitic rocks: Journal of Petrology, v. 42, no. 11, p. 2033-2048.

Gradstein, F.M., Ogg, J.G., Schmitz, M.D., and Ogg, G.M., eds., 2012, The geologic time scale 2012: Boston, Elsevier, $1176 \mathrm{p}$.

Jennings, C.W., Strand, R.G., and Rogers, T.H., 1977, Geologic map of California: California Division of Mines and Geology, scale 1:750,000.

Kistler, R.W., 1990, Two different lithosphere types in the Sierra Nevada, California, in Anderson, J.L., ed., The nature and origin of Cordilleran magmatism: Geological Society of America Memoir 174, p. 271-281.

Kistler, R.W., and Peterman, Z.E., 1978, Reconstruction of crustal blocks of California on the basis of initial strontium isotopic compositions of Mesozoic granitic rocks: U.S. Geological Survey Professional Paper 1071, 17 p.

Kistler, R.W., and Ross, D.C., 1990, A strontium isotopic study of plutons and associated rocks of the southern Sierra Nevada and vicinity, California: U.S. Geological Survey Bulletin 1920, 20 p.

Ludwig, K., 2009, Squid 2, rev. 2.50, a user's manual: Berkeley Geochronology Center Special Publication 5, 110 p.

Ludwig, K., 2012, User's manual for Isoplot 3.75, a geochronological toolkit for Microsoft Excel: Berkeley Geochronology Center Special Publication 4, 75 p. 
McCulloh, T.H., 1952, Geology of the southern half of the Lane Mountain quadrangle, California: Los Angeles, Calif., University of California, Ph.D. dissertation, $182 \mathrm{p}$.

McCulloh, T.H., 1960, Geologic map of the Lane Mountain quadrangle, California: U.S. Geological Survey Open-File Report 60-95, scale 1:48,000.

Middlemost, E.A.K., 1994, Naming materials in the magma/ igneous rock system: Earth-Science Reviews, v. 37, p. 215-224.

Miller, E.L., and Sutter, J.F., 1982, Structural geology and ${ }^{40} \mathrm{Ar}-{ }^{39} \mathrm{Ar}$ geochronology of the Goldstone-Lane Mountain area, Mojave Desert, California: Geological Society of America Bulletin, v. 93, p. 1191-1207.

Miller, J.S., and Glazner, A.F., 1995, Jurassic plutonism and crustal evolution in the central Mojave Desert, California: Contributions to Mineralogy and Petrology, v. 118, p. 379-395.

Miller, J.S., Glazner, A.F., Walker, J.D., and Martin, M.W., 1995, Geochronologic and isotopic evidence for TriassicJurassic emplacement of the eugeoclinal allochthon in the Mojave Desert region, California: Geological Society of America Bulletin, v. 107, p. 1441-1457.
Pearce, J.A., Harris, N.B.W., and Tindle, A.G., 1984, Trace element discrimination diagrams for the tectonic interpretation of granitic rocks: Journal of Petrology, v. 25, no. 4, p. 956-983.

Silberling, N.J., Jones, D.L., Blake, M.C., Jr., and Howell, D.G., 1987, Lithotectonic terranes of the western conterminous United States: U.S. Geological Survey Miscellaneous Field Studies Map MF-1874-C, scale 1:2,500,000, 20 p.

Silberling, N.J., Jones, D.L., Monger, J.W.H., and Coney, P.J., 1992, Lithotectonic terrane map of the North American Cordillera: U.S. Geological Survey Miscellaneous Investigations Series Map I-2176, scale 1:5,000,000.

Singleton, J.S., and Gans, P.B., 2008, Structural and stratigraphic evolution of the Calico Mountains; implications for early Miocene extension and Neogene transpression in the central Mojave Desert, California: Geosphere, v. 4, no. 3, p. 459-479.

Sun, S.-s., and McDonough, W.F., 1989, Chemical and isotopic systematics of oceanic basalts; implications for mantle composition and processes, in Saunders, A.D., and Norry, M.J., eds., Magmatism in the ocean basins: London, Geological Society Special Publication 42, p. 313-345. 
Page left blank intententionally 
Figures and Tables 


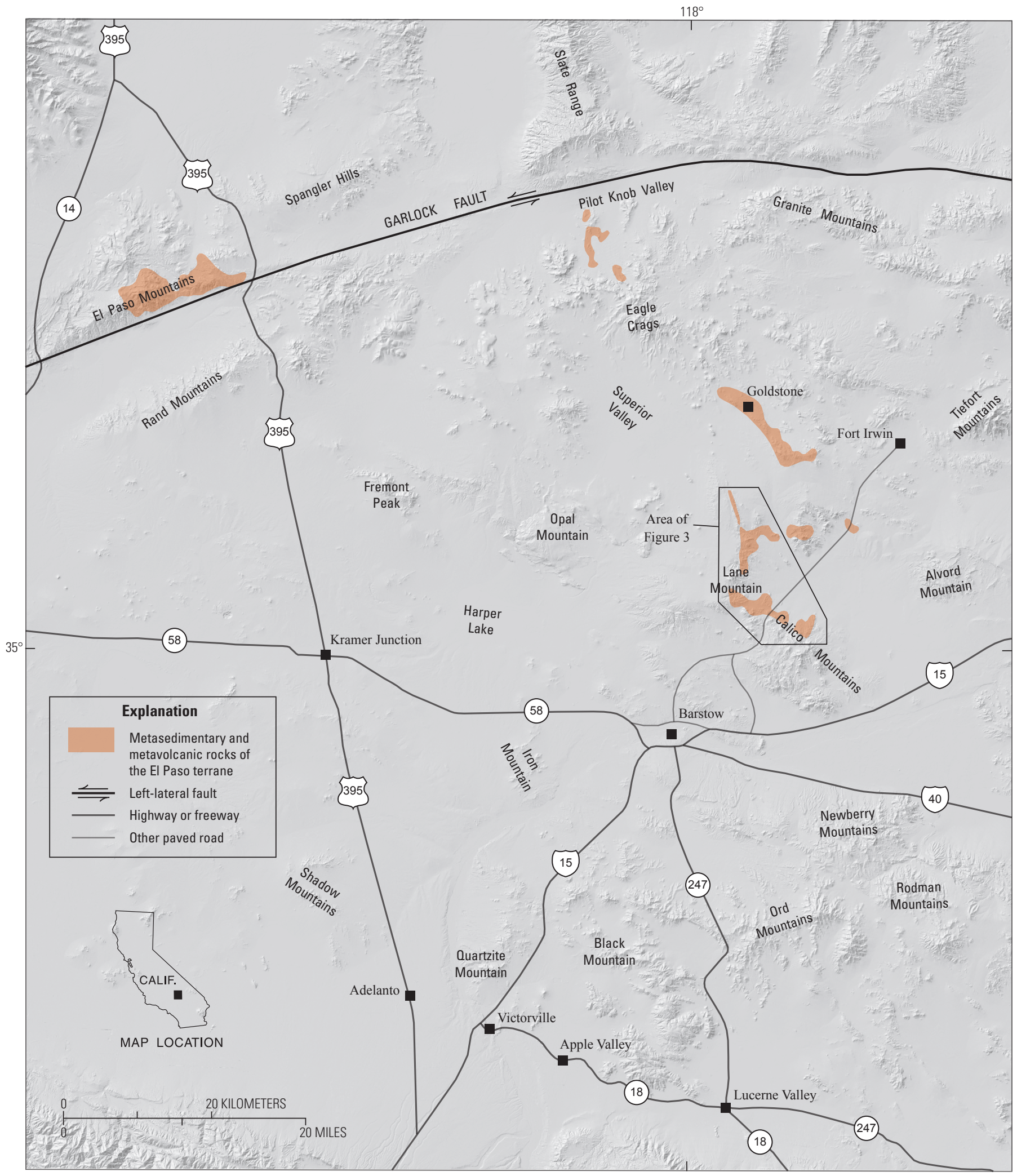

Figure 1. Map of the north-central Mojave Desert region showing outcrops of El Paso terrane (modified from Jennings and others, 1977) and location of report area (fig. 3). 


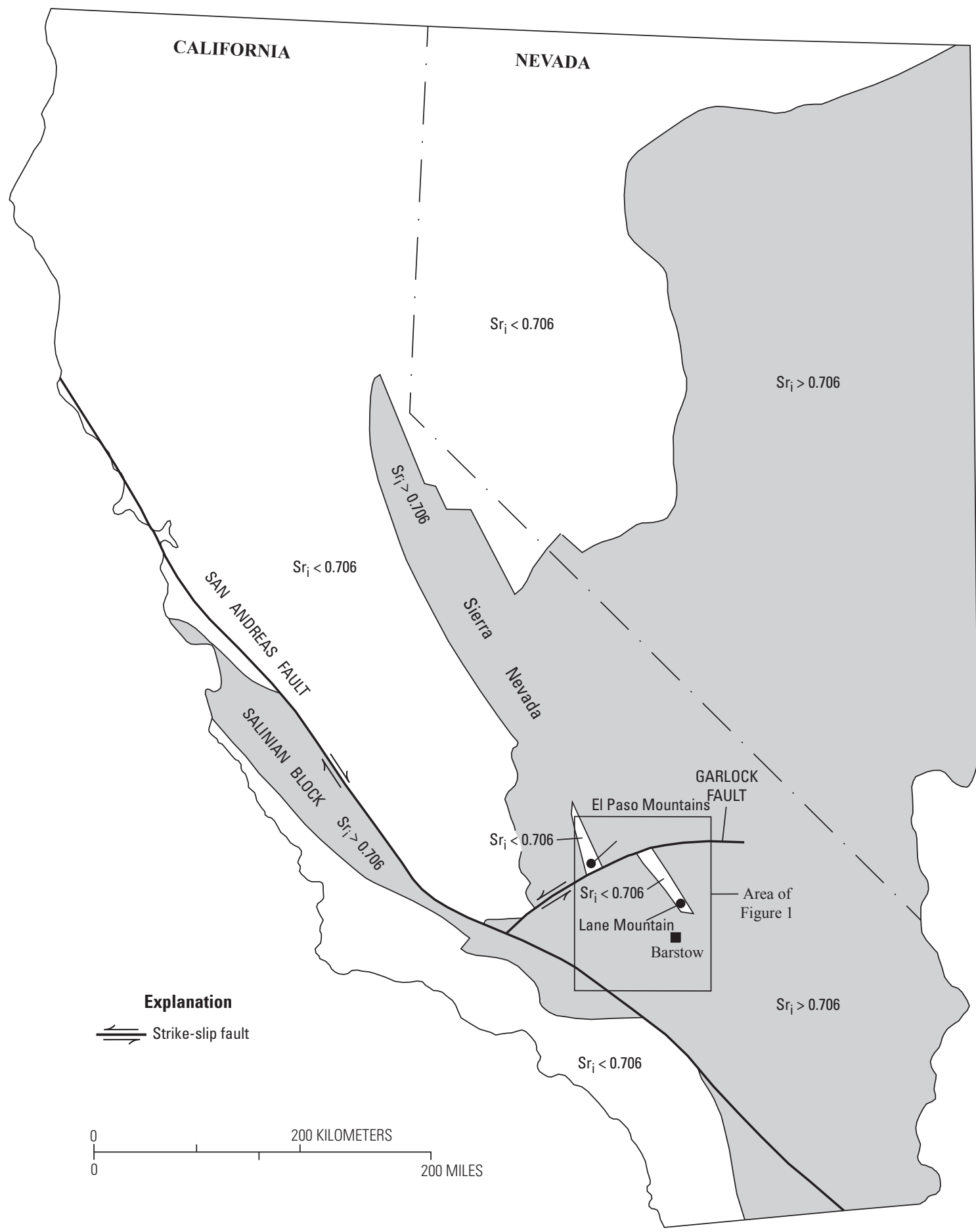

Figure 2. Map showing the $\mathrm{Sr}_{\mathrm{i}}=0.706$ isopleth in California and Nevada (modified from Kistler and Ross, 1990). Shaded areas have $\mathrm{Sr}_{\mathrm{i}}>0.706$. Note narrow, northwest-trending zone of $\mathrm{Sr}_{\mathrm{i}}<0.706$ in the El Paso Mountains-Lane Mountain area. Box shows area of figure 1. 


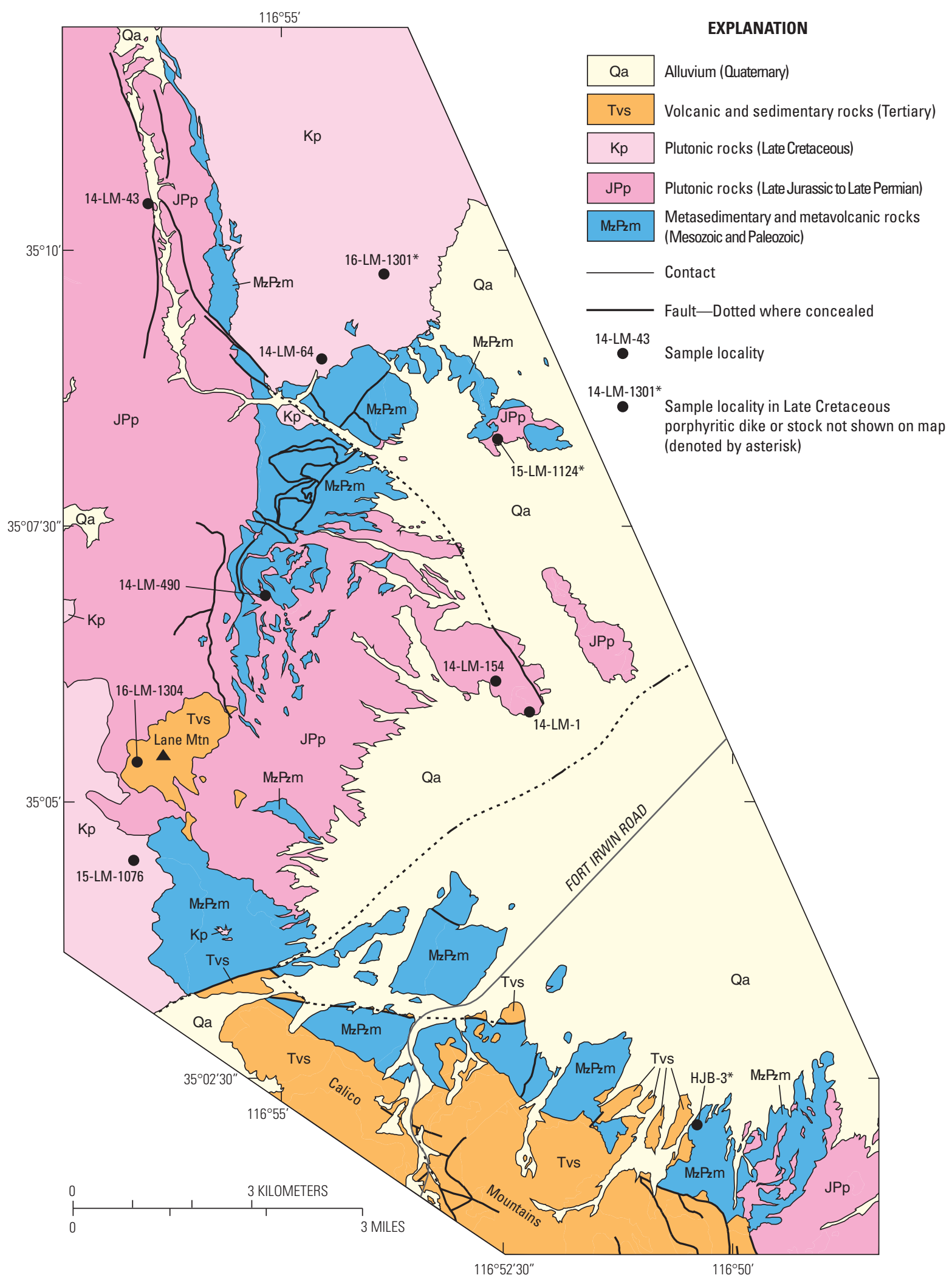

Figure 3. Map showing general geology of Lane Mountain area (modified from McCulloh, 1960) and locations of samples included in this report 

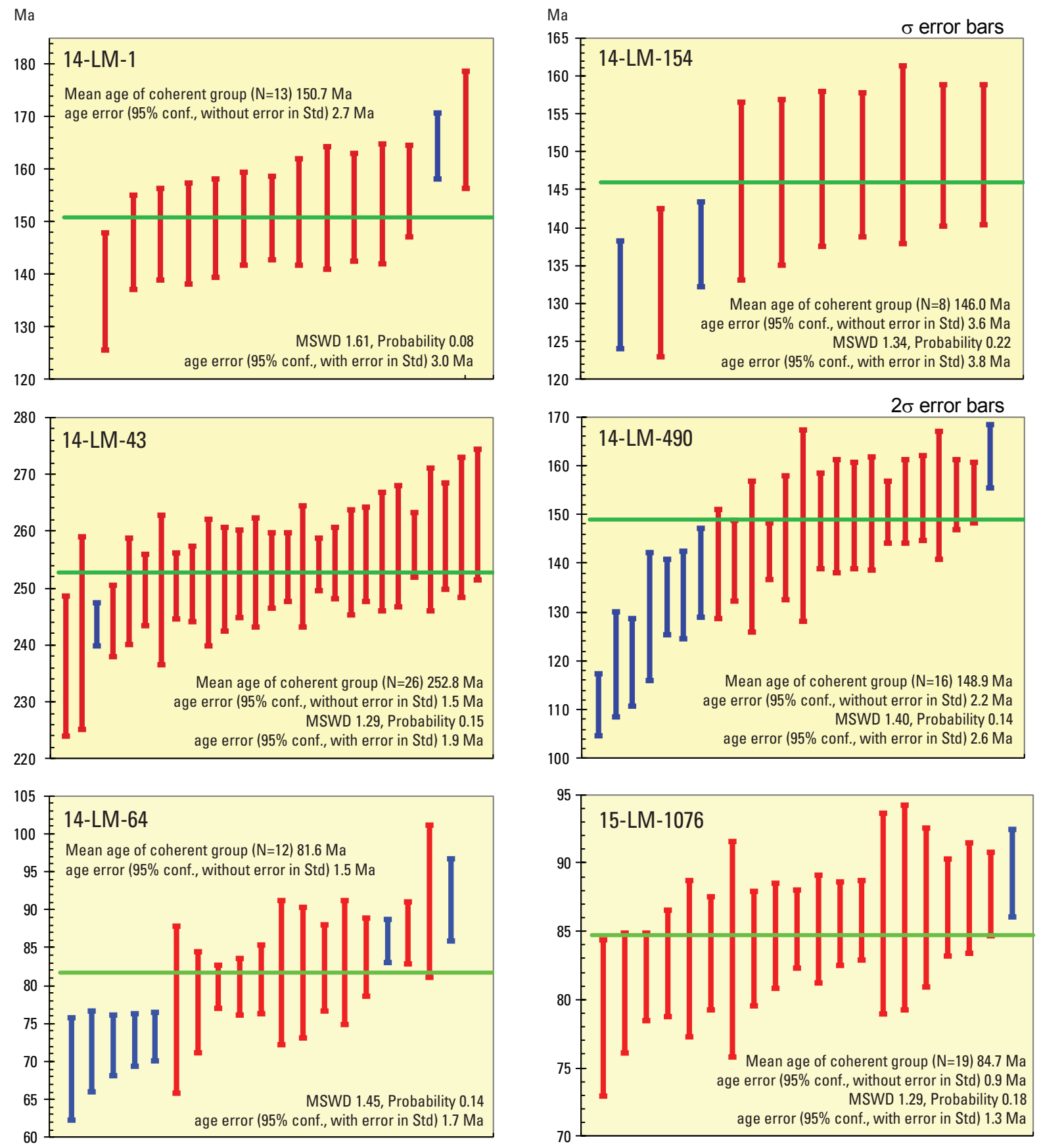

Figure 4. Diagrams showing weighted mean SHRIMP-RG U-Pb zircon ages (green horizontal lines) of samples 14-LM-1, 14-LM-43, 14-LM-64, 14-LM-154, 14-LM-490, and 15-LM-1076. Vertical bars depict 2-sigma errors on $206 \mathrm{~Pb}^{*} / 238 \mathrm{U}$ ages of analyzed spots on zircon crystals. Red bars define coherent groups of spot analyses used for age determinations; blue bars represent spot analyses outside the statistical mean due to inheritance from older rocks or presumed lead loss, which results in a younger age. Some samples contain older and(or) younger spot analyses outside the age limits of the diagrams; see table 3 for complete dataset. MSWD = mean square weighted deviation; $\mathrm{Ma}=$ mega-annum. 

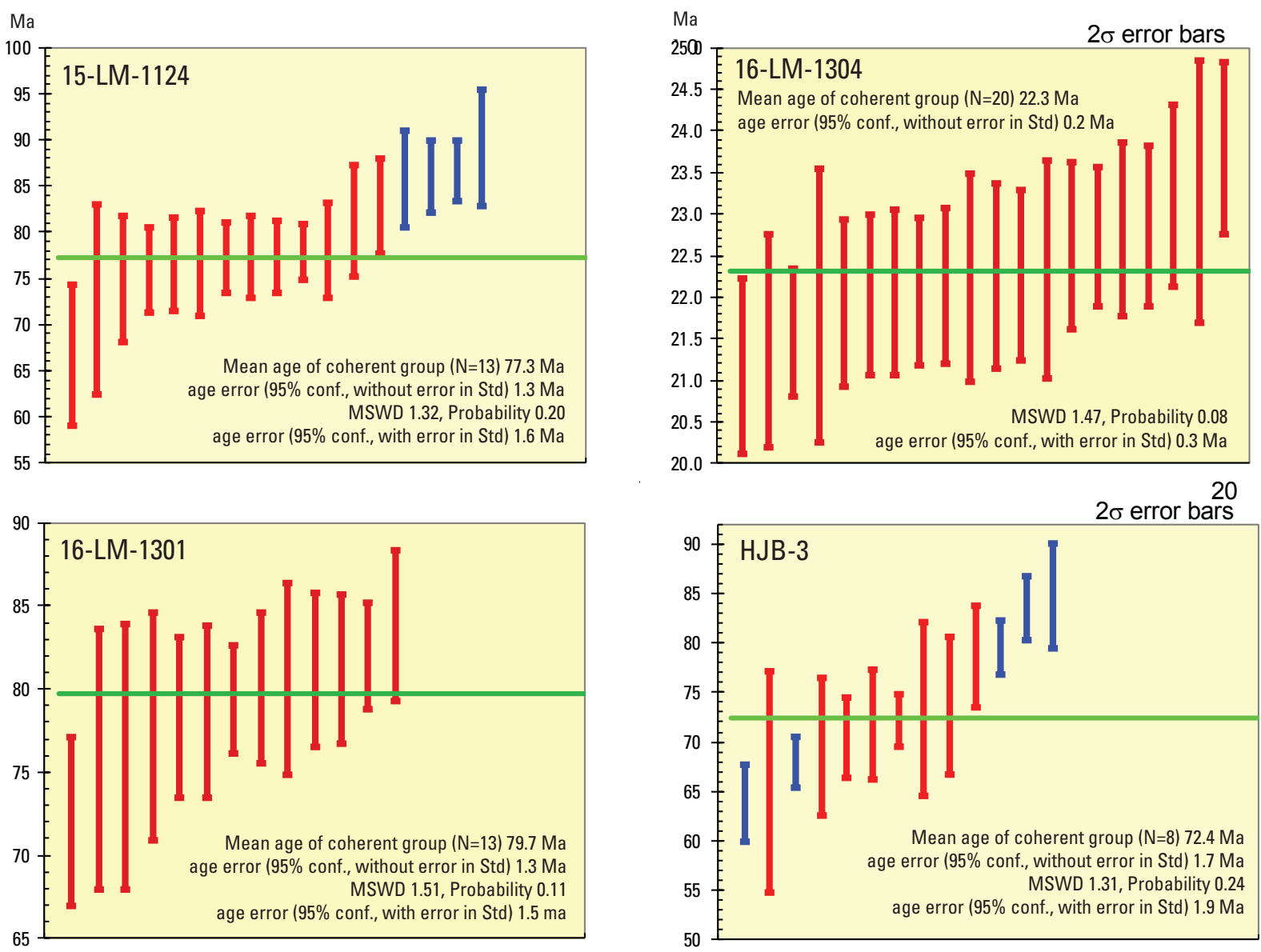

Figure 5. Diagrams showing weighted mean SHRIMP-RG U-Pb zircon ages of samples 15-LM-1124, 16-LM-1301, 16-LM-1304, and HJB-3.Vertical bars depict 2-sigma errors on $206 \mathrm{~Pb}^{*} / 238 \mathrm{U}$ ages of analyzed spots on zircon crystals. Red bars define coherent groups of spot analyses used for age determinations; blue bars represent spot analyses outside the statistical mean due to inheritance from older rocks or presumed lead loss, which results in a younger age. Some samples contain older and(or) younger spot analyses outside the age limits of the diagrams; see table 3 for complete dataset. MSWD = mean square weighted deviation; $\mathrm{Ma}=$ mega-annum.

Figure 6. Diagram showing increase of $\mathrm{Sr}_{\text {, }}$ with decreasing age of plutonic rock samples in the Lane Mountain area. This increase of $\mathrm{Sr}_{i}$ suggests an increasing involvement of Precambrian lithosphere in the generation of magmas through time. $\mathrm{Ma}=$ mega-annum.

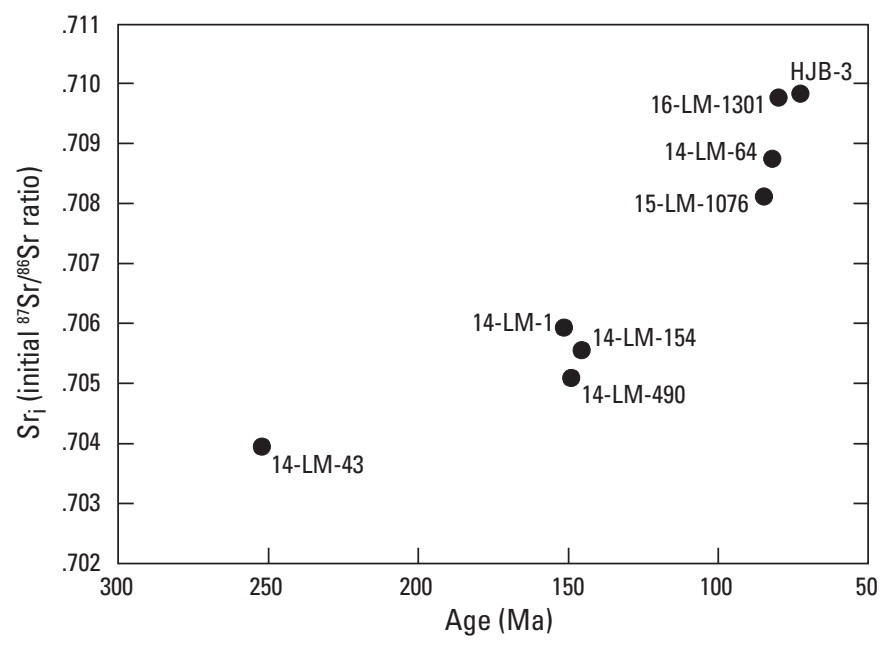




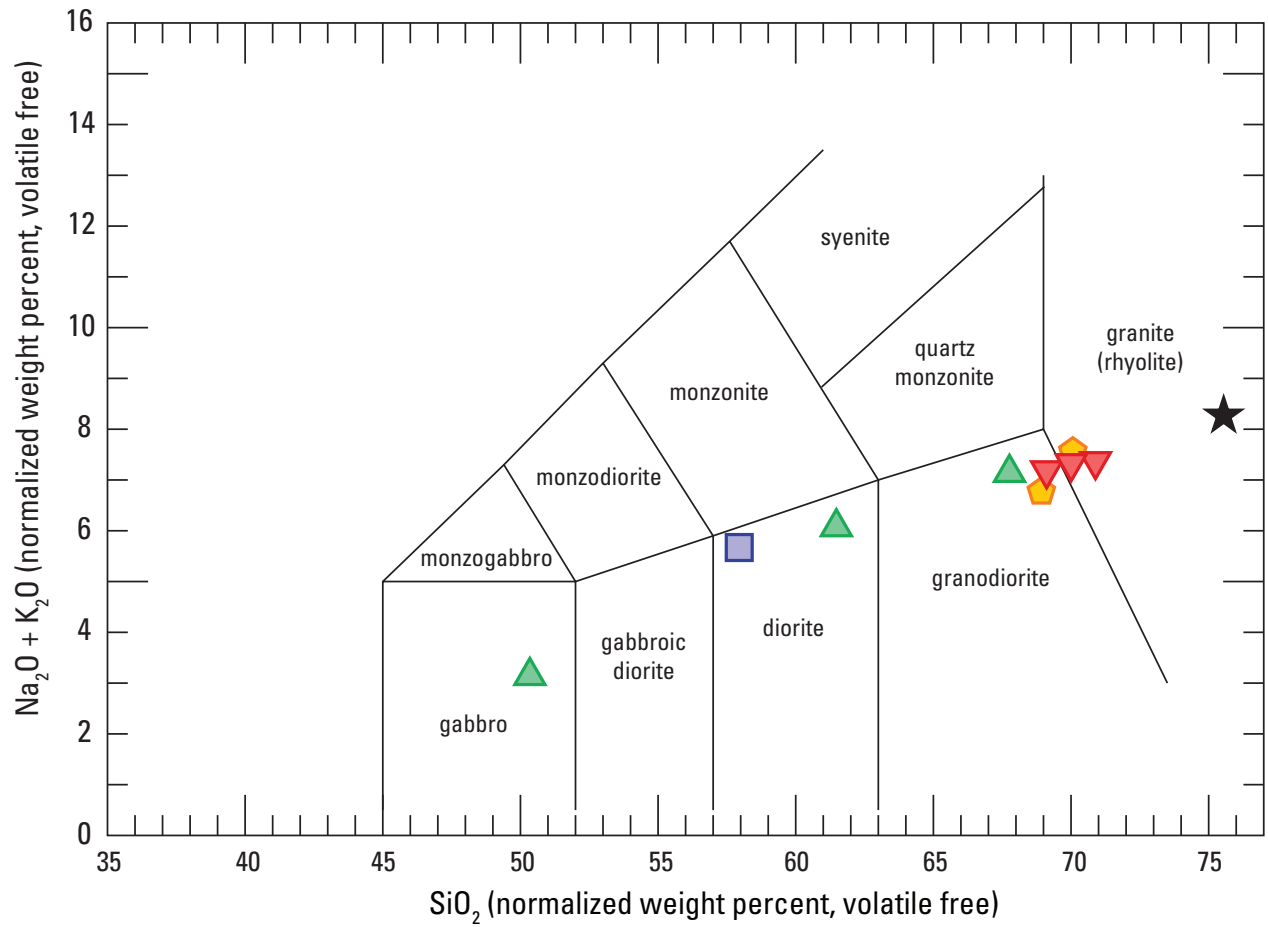

EXPLANATION

Rhyolite of Lane

Mountain (Miocene)

Porphyritic dikes and

stocks (Late

Cretaceous)

Plutonic rocks (Late Cretaceous)

Plutonic rocks (Late Jurassic)

Plutonic rocks (Early

Triassic to late

Permian)

Figure 7. Modified total alkali-silica (TAS) diagram showing the classification of samples included in this report. Plutonic rock names are from Middlemost (1994).

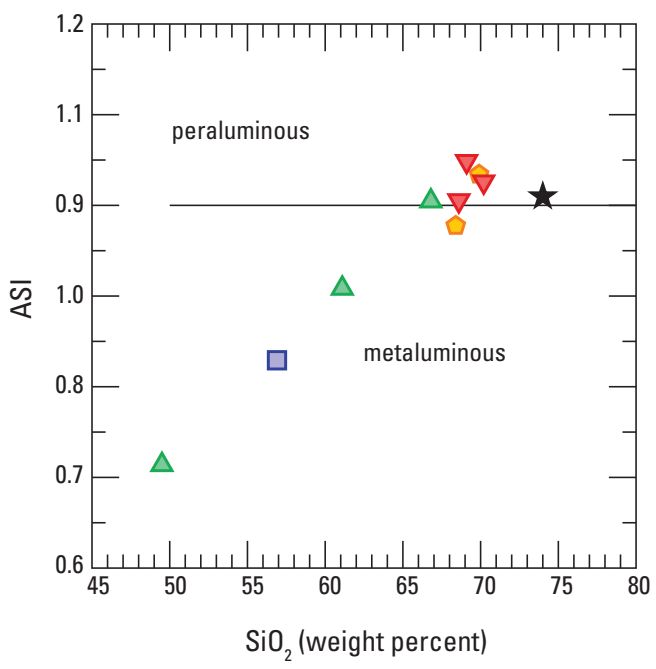

Figure 8. Diagram showing the aluminum saturation index (ASI) (Frost and others, 2001) for samples included in this report. ASI is the molecular ratio $\mathrm{Al} /(\mathrm{Ca}-1.67 \mathrm{P}+\mathrm{Na}+\mathrm{K})$.

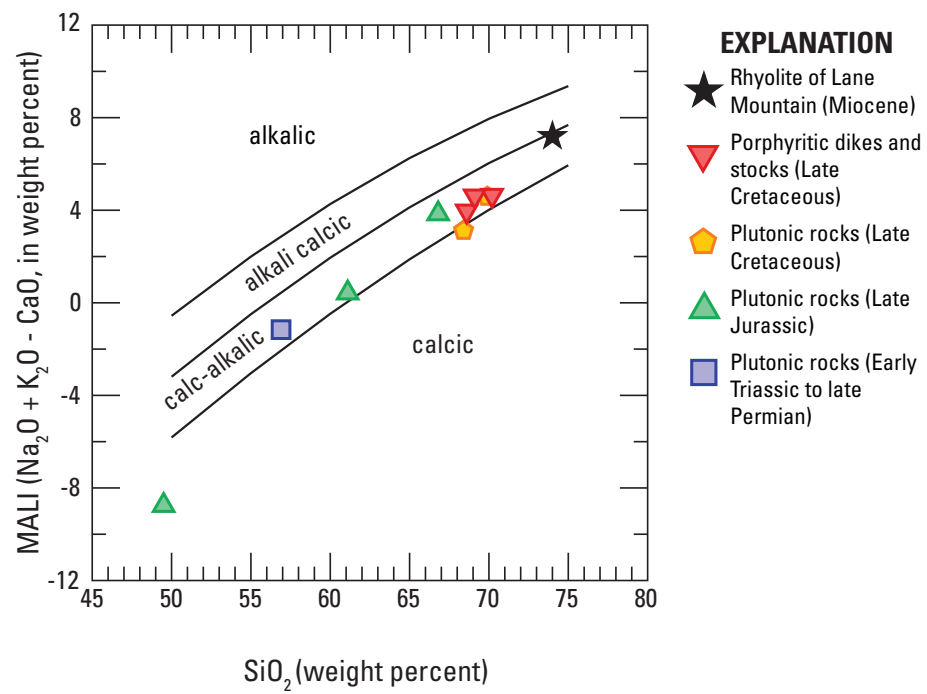

Figure 9. Diagram showing the modified alkali-lime index (MALI) (Frost and others, 2001) for samples included in this report. 


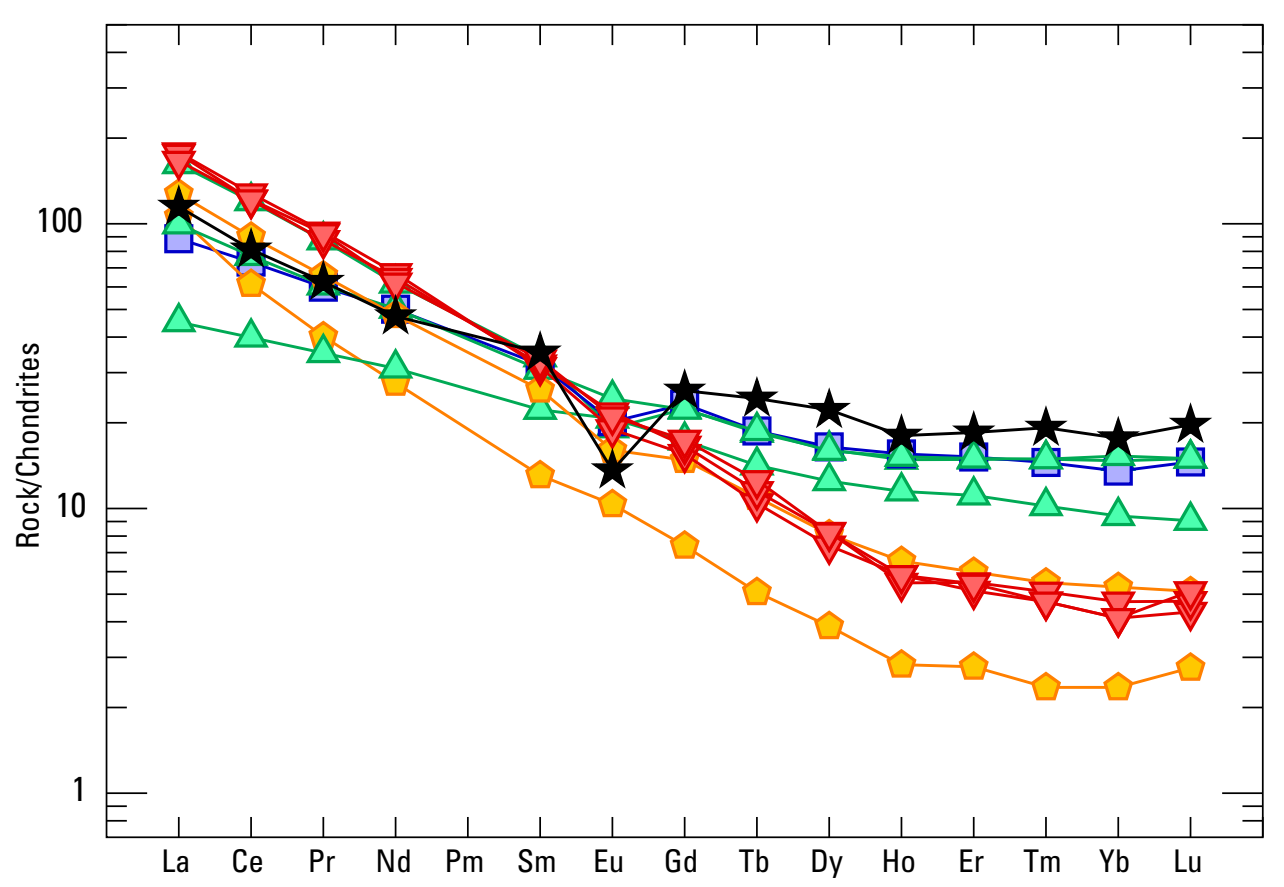

\section{EXPLANATION}

Rhyolite of Lane

Mountain (Miocene)

$\nabla$ Porphyritic dikes and

stocks (Late

Cretaceous)

Plutonic rocks (Late

Cretaceous)

Plutonic rocks (Late

Jurassic)

Plutonic rocks (Early

Triassic to late

Permian)

Figure 10. Diagram showing rareearth element (REE) abundances normalized to chondrite values (Sun and McDonough, 1989) for samples included in this report. Y-axis (logarithmic scale) indicates the relative abundances (in parts per million) of each element in the sampled rocks versus that in chondrites.

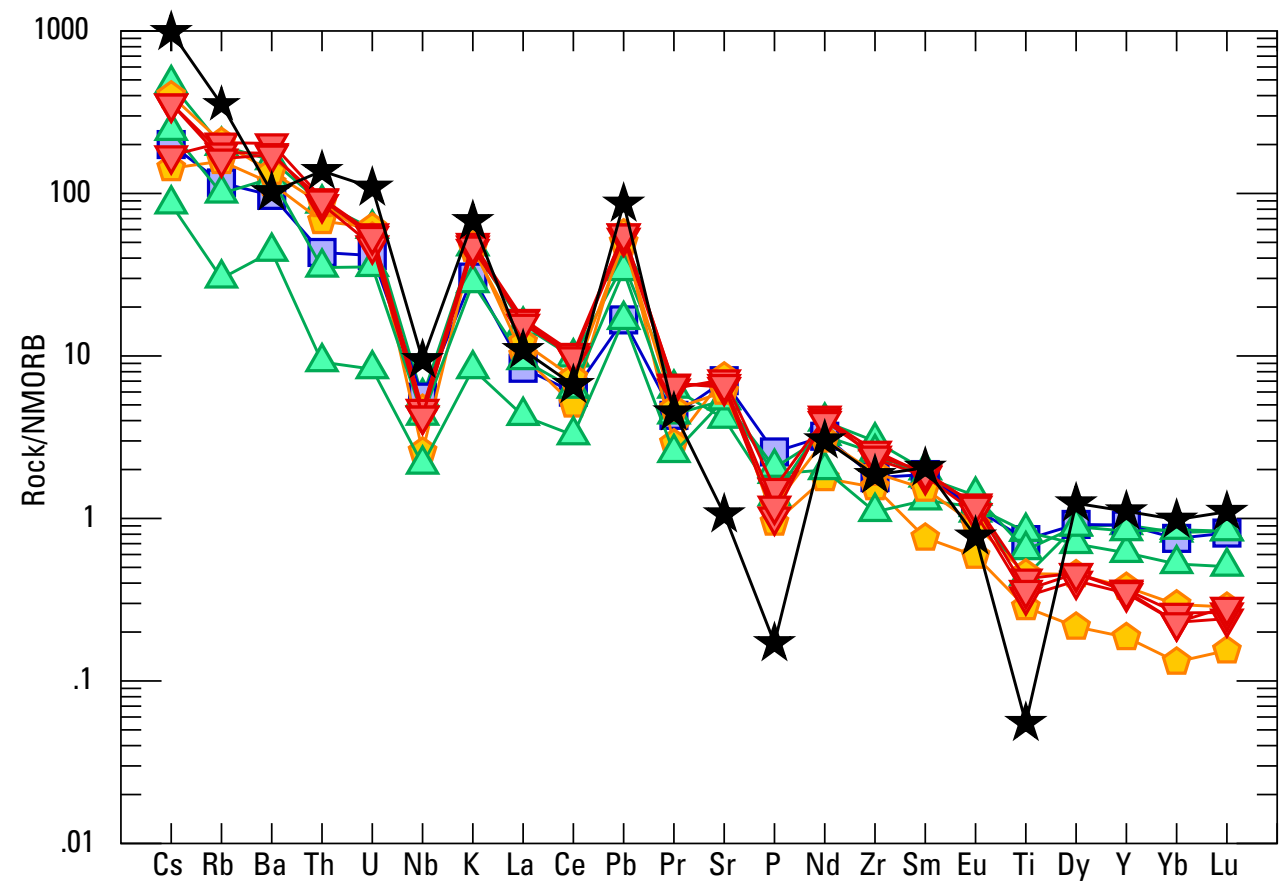

\section{EXPLANATION}

Rhyolite of Lane

Mountain (Miocene)

$\nabla$ Porphyritic dikes and

stocks (Late

Cretaceous)

Plutonic rocks (Late

Cretaceous)

Plutonic rocks (Late

Jurassic)

Plutonic rocks (Early

Triassic to late

Permian)

Figure 11. Diagram showing trace element (TE) abundances normalized to normal-mid-ocean ridge-basalt (NMORB) (Sun and McDonough, 1989) for samples included in this report. Y-axis indicates the relative abundances (in parts per million) of each element in the sampled rocks versus that in NMORB. 

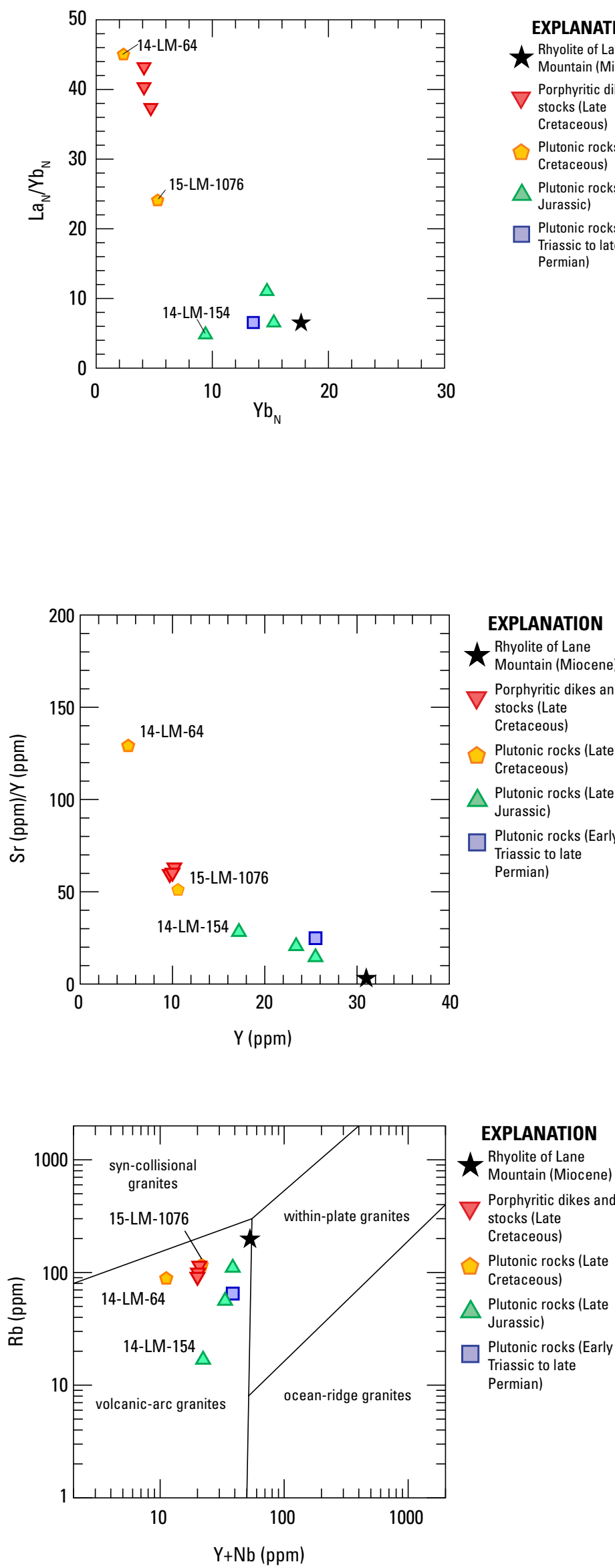

\section{EXPLANATION}

Rhyolite of Lane

Mountain (Miocene)

Porphyritic dikes and

stocks (Late Cretaceous)

Plutonic rocks (Late Cretaceous)

$\triangle$ Plutonic rocks (Late Jurassic)

Plutonic rocks (Early Triassic to late Permian)
EXPLANATION

A Rhyolite of Lane

Mountain (Miocene)

$\checkmark$ Porphyritic dikes and stocks (Late Cretaceous)

Plutonic rocks (Late Cretaceous)

$\triangle$ Plutonic rocks (Late Jurassic)

Plutonic rocks (Early

Triassic to late Permian)
Figure 12. Diagram showing $\mathrm{La}_{N} / \mathrm{Yb}_{N} v \mathrm{Vs}_{\mathrm{N}}$ for samples included in this report. $\mathrm{La}_{\mathrm{N}}$ and $\mathrm{Yb}_{\mathrm{N}}$ are chondrite-normalized values obtained by dividing the La and $\mathrm{Yb}$ concentrations in the rock by those in the average chondrite (Sun and McDonough, 1989). Selected samples are identified by number for purposes of discussion (see text).
Figure 13. Diagram showing $S r / Y$ vs. Y for samples included in this report. Selected samples are identified by number for purposes of discussion (see text).
Figure 14. Diagram showing $\mathrm{Rb} v \mathrm{vs} . \mathrm{Y}+\mathrm{Nb}$ in samples included in this report, with their inferred intrusive settings (Pearce and others, 1984). Selected samples are identified by number for purposes of discussion (see text). 
Table 1. Location and basic lithologic, geochronologic, isotopic, and geochemical information for rock samples studied for this report.

[Values for $\mathrm{SiO}_{2}$ and $\mathrm{K}_{2} \mathrm{O}+\mathrm{Na}_{2} \mathrm{O}$ are in normalized weight percent (volatile free). $\mathrm{Sr}_{\mathrm{i}}$, is the calculated initial ${ }^{87} \mathrm{Sr} /{ }^{86} \mathrm{Sr}$ ratio; Ma, mega-annum. See tables $2-6$ for detailed information]

\begin{tabular}{|c|c|c|c|c|c|c|c|c|}
\hline Sample No. & $\begin{array}{l}\text { Latitude (N) } \\
\text { Longitude (W) } \\
\text { (NAD27) }\end{array}$ & $\begin{array}{c}\text { Map } \\
\text { Unit } \\
\text { (Fig. 2) }\end{array}$ & $\begin{array}{l}\text { Unit of McCulloh } \\
(1960)\end{array}$ & Lithology & Age (Ma) & $\mathrm{Sr}_{\mathrm{i}}$ & $\begin{array}{l}\mathrm{SiO}_{2} \\
(\%)\end{array}$ & $\begin{array}{c}\mathrm{K}_{2} \mathrm{O}+\mathrm{Na}_{2} \mathrm{O} \\
(\%)\end{array}$ \\
\hline 14-LM-1 & $\begin{array}{l}35^{\circ} 05^{\prime} 50.9^{\prime \prime} \\
116^{\circ} 52^{\prime} 16.8^{\prime \prime}\end{array}$ & $\mathrm{JPp}$ & $\begin{array}{c}\text { Daisy } \\
\text { granodiorite }\end{array}$ & Granodiorite & $150.7 \pm 2.7$ & 0.70590 & 67.50 & 7.21 \\
\hline 14-LM-43 & $\begin{array}{l}35^{\circ} 10^{\prime} 24.0 " \\
116^{\circ} 56^{\prime} 32.1 "\end{array}$ & $\mathrm{JPp}$ & Larrea complex & Quartz diorite & $252.8 \pm 1.5$ & 0.70396 & 57.47 & 5.73 \\
\hline 14-LM-64 & $\begin{array}{l}35^{\circ} 09^{\prime} 00.8^{\prime \prime} \\
116^{\circ} 54^{\prime} 36.7 "\end{array}$ & $\mathrm{Kp}$ & $\begin{array}{c}\text { Jack Spring } \\
\text { quartz } \\
\text { monzonite }\end{array}$ & Granite & $81.6 \pm 1.5$ & 0.70877 & 69.92 & 7.56 \\
\hline 14-LM-154 & $\begin{array}{l}35^{\circ} 06^{\prime} 07.2^{\prime \prime} \\
116^{\circ} 52^{\prime} 39.3 "\end{array}$ & $\mathrm{JPp}$ & Larrea complex & Gabbro & $146.0 \pm 3.6$ & 0.70553 & 49.96 & 3.17 \\
\hline 14-LM-490 & $\begin{array}{l}35^{\circ} 06^{\prime} 51.6 " \\
116^{\circ} 55^{\prime} 12.4 ”\end{array}$ & JPp & Larrea complex & Quartz diorite & $148.9 \pm 2.2$ & 0.70511 & 61.08 & 6.07 \\
\hline 15-LM-1076 & $\begin{array}{l}35^{\circ} 04^{\prime} 27.0 \prime \\
116^{\circ} 56^{\prime} 36.4 \prime\end{array}$ & $\mathrm{Kp}$ & $\begin{array}{c}\text { Jack Spring } \\
\text { quartz } \\
\text { monzonite }\end{array}$ & Granodiorite & $84.7 \pm 0.9$ & 0.70809 & 68.69 & 6.80 \\
\hline 15-LM-1124 & $\begin{array}{l}35^{\circ} 08^{\prime} 18.5^{\prime \prime} \\
116^{\circ} 52^{\prime} 39.7^{\prime},\end{array}$ & - & $\begin{array}{l}\text { Quartz latite } \\
\text { porphyry } \\
\text { dike }\end{array}$ & $\begin{array}{l}\text { Granite } \\
\text { porphyry }\end{array}$ & $77.3 \pm 1.3$ & - & 70.72 & 7.42 \\
\hline 16-LM-1301 & $\begin{array}{l}35^{\circ} 09^{\prime} 47.7 " \\
116^{\circ} 53^{\prime \prime} 56.1 "\end{array}$ & - & Not mapped & $\begin{array}{l}\text { Granodiorite } \\
\text { porphyry }\end{array}$ & $79.7 \pm 1.3$ & 0.70976 & 68.90 & 7.22 \\
\hline 16-LM-1304 & $\begin{array}{l}35^{\circ} 05^{\prime} 20.9 ” \\
116^{\circ} 56^{\prime} 35.7 \prime\end{array}$ & Tvs & $\begin{array}{c}\text { Lane Mountain } \\
\text { volcanics }\end{array}$ & Rhyolite & $22.3 \pm 0.2$ & - & 75.42 & 8.43 \\
\hline HJB-3 & $\begin{array}{l}35^{\circ} 02^{\prime} 07.6^{\prime \prime} \\
116^{\circ} 50^{\prime} 22.3 \prime\end{array}$ & - & Not mapped & $\begin{array}{l}\text { Granite } \\
\text { porphyry }\end{array}$ & $72.4 \pm 1.7$ & 0.70985 & 69.81 & 7.41 \\
\hline
\end{tabular}


Table 2. Sample descriptions, Lane Mountain area, San Bernardino County, California.

\section{Sample \\ Lithologic Description}

14-LM-1 Medium-grained (1-3 mm) plutonic rock composed of $\sim 30 \%$ quartz, $30 \%$ potassium feldspar, $20 \%$ plagioclase, and $20 \%$ mafic minerals. Plagioclase euhedral to subhedral; potassium feldspar is poikilitic. Primary mafic mineral is biotite; hornblende and opaque minerals are minor. Mafic minerals generally form irregular, multi-crystalline clots; some biotite forms single crystals to $1.5 \mathrm{~mm}$ long. Opaque minerals minor.

14-LM-43 Medium- to coarse grained (3-4 mm) plutonic rock composed of $\sim 45 \%$ plagioclase, $15 \%$ potassium feldspar, $10 \%$ quartz, and 30\% mafic minerals. Plagioclase forms subhedral to nearly euhedral crystals as long as $3 \mathrm{~mm}$; other minerals are anhedral. Mafic minerals are hornblende, pyroxene(?), biotite, and opaques, all commonly occurring together in irregular, multi-crystalline clots.

14-LM-64 Medium-grained (1-3 mm) plutonic rock composed of $\sim 40 \%$ plagioclase, 30\% potassium feldspar, 25\% quartz, and 5\% mafic minerals. Plagioclase anhedral to euhedral, partly sericitized; potassium feldspar is poikilitic microcline. Primary mafic mineral is biotite that generally occurs as single crystals. Small crystals of hornblende are rare. Accessory sphene is conspicuous in thin section.

14-LM-154 Medium-grained ( $\sim 2 \mathrm{~mm})$ plutonic rock composed of subequal amounts of plagioclase and mafic minerals and $<5 \%$ quartz. Plagioclase is well preserved and forms randomly oriented, subhedral laths. Only mafic mineral is hornblende that forms irregular clots approximately $4 \mathrm{~mm}$ across.

14-LM-490 Medium-grained (2-3 mm) plutonic rock composed of $\sim 35 \%$ plagioclase, $10 \%$ potassium feldspar, $15 \%$ quartz, and $40 \%$ mafic minerals. Plagioclase is well preserved and forms subhedral to euhedral crystals as long as $3 \mathrm{~mm}$. Potassium feldspar forms small, irregular, fine-grained, polycrystalline enclaves. Mafic minerals consist of subequal biotite and hornblende that are closely associated in irregular clots.

15-LM-1076 Coarse-grained (3-5 mm) plutonic rock composed of $\sim 35 \%$ plagioclase, 30\% potassium feldspar, $25 \%$ quartz, and $10 \%$ mafic minerals. Plagioclase forms anhedral to euhedral, blocky crystals as long as $5 \mathrm{~mm}$. Potassium feldspar is anhedral and surrounds plagioclase. Quartz forms large anhedral crystals as wide as $5 \mathrm{~mm}$. Mafic minerals, mostly or entirely biotite, form irregular crystals approximately $7 \mathrm{~mm}$ across.

15-LM-1124 Porphyritic plutonic rock composed of a fine-grained felsic groundmass and $\sim 50 \%$ phenocrysts as much as $\sim 7 \mathrm{~mm}$ across. In decreasing order of abundance, phenocrysts are plagioclase, quartz, and potassium feldspar. Plagioclase phenocrysts are commonly tabular and euhedral; potassium feldspar phenocrysts are blocky; quartz phenocrysts range from euhedral to subspherical. Small mafic crystals (biotite and minor hornblende), mostly $<1 \mathrm{~mm}$ across, make up $\sim 15 \%$ of the rock.

16-LM-1301 Porphyritic plutonic rock composed of a fine-grained felsic groundmass and $\sim 60 \%$ plagioclase and quartz phenocrysts mostly $\leq 5 \mathrm{~mm}$ across. Biotite phenocrysts $\leq 1 \mathrm{~mm}$ across make up $\sim 15 \%$ of the rock. Small sphene phenocrysts, visible in thin section, are rare. Thin section shows complex intergrowths of potassium feldspar crystals in groundmass.

16-LM-1304 Reddish-brown, flow-banded volcanic rock containing $\sim 20 \%$ small phenocrysts of quartz, plagioclase, biotite, and rare hornblende in a glassy to finely crystalline groundmass. Phenocrysts are mostly $\leq 1.5 \mathrm{~mm}$ across and mostly euhedral to subhedral; some quartz phenocrysts are subspherical.

HJB-3 Porphyritic plutonic rock composed of a fine-grained felsic groundmass and $\sim 50 \%$ quartz and plagioclase phenocrysts as long as $10 \mathrm{~mm}$. Plagioclase phenocrysts are partially to completely sericitized. Quartz phenocrysts range from anhedral to nearly euhedral. Small biotite crystals, which are commonly replaced by chlorite, make up $\sim 5 \%$ of rock. Small sphene phenocrysts are rare but conspicuous in thin section. 
Table 3. SHRIMP-RG U-Pb zircon data for samples analyzed in this report, Lane Mountain area.

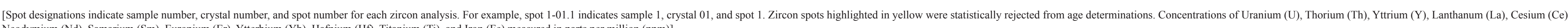

\begin{tabular}{|c|c|c|c|c|c|c|c|c|c|c|c|c|c|c|c|c|c|c|c|c|c|c|c|c|c|c|}
\hline Spot & ${ }^{244} \mathrm{~Pb} / 010 \mathrm{~Pb}$ & $\pm \%$ & ${ }^{207} \mathrm{~Pb} / 200 \mathrm{~Pb}$ & $\pm \%$ & ${ }^{208} \mathrm{~Pb} /{ }^{200} \mathrm{~Pb}$ & $\pm \%$ & $\begin{array}{c}\% \\
206 \mathrm{~Pb}_{\mathrm{c}}\end{array}$ & $\underset{U}{\mathrm{ppm}}$ & $\begin{array}{c}\mathrm{ppm} \\
\mathrm{Th}\end{array}$ & $\begin{array}{c}\text { Total } \\
{ }^{206 \mathrm{~Pb}} \mathrm{p}^{38 \mathrm{U}} \mathrm{U}\end{array}$ & $\pm \%$ & \multicolumn{2}{|c|}{$\begin{array}{l}{ }^{200 \mathrm{~Pb}} \mathrm{p}^{238 \mathrm{U}} \\
\mathrm{Age} \mathrm{(Ma)}\end{array}$} & $\begin{array}{c}Y \\
(\mathrm{ppm})\end{array}$ & $\begin{array}{c}\text { La } \\
\text { (ppm) }\end{array}$ & Ce (ppm) & $\begin{array}{c}\mathrm{Nd} \\
(\mathrm{ppm})\end{array}$ & $\begin{array}{c}\mathbf{S m} \\
(\mathrm{ppm})\end{array}$ & $\begin{array}{c}\text { Eu } \\
\text { (ppm) }\end{array}$ & Gd (ppm) & $\begin{array}{c}\mathrm{Dy} \\
(\mathrm{ppm})\end{array}$ & $\begin{array}{c}\mathrm{Er} \\
(\mathrm{ppm})\end{array}$ & $\begin{array}{c}\mathrm{Yb} \\
(\mathrm{ppm})\end{array}$ & $\underset{\substack{\mathrm{Hf} \\
(\mathrm{ppm})}}{\mathrm{HF}}$ & $\begin{array}{c}\mathrm{T} \\
(\mathrm{ppm})\end{array}$ & $\begin{array}{c}\mathrm{Fe} \\
(\mathrm{ppm})\end{array}$ \\
\hline \multicolumn{27}{|c|}{ Sample 14-LM-1 } \\
\hline $1-01.1$ & - & - & 0.0504 & 4.3 & 0.17 & 4.9 & 0.16 & 143 & 70 & 0.0237 & 2.6 & 151 & \pm 4 & 592.9 & 0.01 & 15.1 & 0.4 & 1.1 & 0.3 & 11.5 & 47.8 & 105.6 & 211.4 & $7,642.5$ & 9.0 & 2.7 \\
\hline $1-02.1$ & $6.1 \mathrm{E}-4$ & 18 & 0.0621 & 2.2 & 0.12 & 3.7 & 1.77 & 1,834 & 604 & 0.0158 & 3.9 & 99.5 & \pm 4 & $1,371.7$ & 11.53 & 141.7 & 29.2 & 22.2 & 6.7 & 58.6 & 121.3 & 229.7 & 539.4 & $9,583.9$ & 64.3 & 204.4 \\
\hline $1-03.1$ & $9.9 \mathrm{E}-4$ & 38 & 0.0500 & 4.2 & 0.14 & 5.4 & 0.11 & 121 & 53 & 0.0240 & 3.8 & 153 & \pm 6 & 604.2 & 0.01 & 13.5 & 0.4 & 1.1 & 0.3 & 11.1 & 48.5 & 110.0 & 230.9 & $7,336.2$ & 9.6 & 2.2 \\
\hline $1-04.1$ & $5.1 \mathrm{E}-4$ & 58 & 0.0520 & 4.5 & 0.18 & 5.2 & 0.36 & 109 & 55 & 0.0239 & 3.3 & 152 & \pm 5 & 546.0 & 0.05 & 11.3 & 0.4 & 1.2 & 0.4 & 11.8 & 46.0 & 100.1 & 198.8 & $7,198.0$ & 11.7 & 3.1 \\
\hline $1-05.1$ & $1.2 \mathrm{E}-4$ & 100 & 0.0477 & 4.0 & 0.16 & 4.6 & - & 149 & 71 & 0.0236 & 2.9 & 151 & \pm 4 & 491.3 & 0.01 & 14.6 & 0.3 & 1.0 & 0.3 & 9.6 & 40.4 & 89.5 & 192.5 & $7,442.4$ & 7.7 & 2.4 \\
\hline $1-06.2$ & $8.9 \mathrm{E}-4$ & 33 & 0.0590 & 3.4 & 0.11 & 5.2 & 1.21 & 387 & 100 & 0.0261 & 1.9 & 164 & \pm 3 & 381.8 & 2.81 & 15.0 & 0.2 & 0.5 & 0.1 & 6.0 & 27.7 & 64.5 & 145.3 & $6,222.9$ & 4.7 & 17.3 \\
\hline $1-07.2$ & $6.5 \mathrm{E}-4$ & 45 & 0.0531 & 3.9 & 0.15 & 5.0 & 0.52 & 134 & 54 & 0.0230 & 3.1 & 146 & \pm 4 & 394.5 & 0.01 & 13.9 & 0.2 & 0.6 & 0.2 & 6.7 & 32.4 & 72.2 & 162.3 & $8,424.4$ & 6.9 & 3.2 \\
\hline $1-08.2$ & $-5.7 \mathrm{E}-4$ & 58 & 0.0559 & 4.7 & 0.15 & 11.9 & 0.87 & 100 & 46 & 0.0236 & 3.1 & 149 & \pm 5 & 478.1 & 0.00 & 12.9 & 0.4 & 1.2 & 0.4 & 11.1 & 42.5 & 85.4 & 171.3 & $8,357.7$ & 7.8 & 0.7 \\
\hline $1-09.2$ & $3.9 \mathrm{E}-4$ & 100 & 0.0740 & 6.1 & 0.26 & 6.6 & 3.09 & 140 & 88 & 0.0272 & 3.3 & 167 & \pm 6 & 685.5 & 2.38 & 14.1 & 0.9 & 2.0 & 0.5 & 17.9 & 51.1 & 105.3 & 178.9 & $4,213.9$ & 7.6 & 99.5 \\
\hline $1-10.2$ & $1.6 \mathrm{E}-4$ & 100 & 0.0531 & 4.3 & 0.17 & 5.0 & 0.51 & 123 & 56 & 0.0233 & 3.0 & 148 & \pm 4 & 507.0 & 0.01 & 12.9 & 0.2 & 0.8 & 0.3 & 9.4 & 40.5 & 91.8 & 194.2 & $7,740.4$ & 7.3 & 1.7 \\
\hline $1-11.2$ & $6.0 \mathrm{E}-4$ & 33 & 0.0546 & 2.8 & 0.18 & 5.3 & 0.73 & 301 & 135 & 0.0216 & 4.1 & 137 & \pm 6 & 513.4 & 0.12 & 18.8 & 0.3 & 0.9 & 0.2 & 8.7 & 39.3 & 90.7 & 193.6 & $6,841.3$ & 4.5 & 9.3 \\
\hline $1-12.1$ & - & - & 0.0486 & 3.6 & 0.24 & 3.5 & - & 195 & 143 & 0.0240 & 3.4 & 153 & \pm 5 & $1,497.4$ & 0.04 & 16.0 & 2.3 & 4.9 & 1.3 & 40.7 & 124.3 & 256.0 & 443.6 & $7,189.3$ & 12.7 & 0.9 \\
\hline $1-13.1$ & $1.4 \mathrm{E}-3$ & 32 & 0.0569 & 14.0 & 0.24 & 12.1 & 0.97 & 129 & 84 & 0.0247 & 2.6 & 156 & \pm 4 & 911.5 & 0.05 & 12.7 & 1.4 & 2.7 & 0.8 & 23.9 & 78.2 & 157.4 & 287.9 & $7,202.6$ & 12.1 & 6.1 \\
\hline $1-14.1$ & $1.0 \mathrm{E}-3$ & 35 & 0.0514 & 4.4 & 0.17 & 4.6 & 0.29 & 142 & 66 & 0.0242 & 3.8 & 153 & \pm 6 & 504.7 & 0.01 & 17.1 & 0.3 & 0.9 & 0.2 & 9.5 & 46.5 & 92.7 & 185.1 & $8,767.4$ & 8.3 & 3.1 \\
\hline $1-15.1$ & 4.6E-4 & 50 & 0.0518 & 3.9 & 0.25 & 3.6 & 0.35 & 158 & 109 & 0.0233 & 3.3 & 148 & \pm 5 & 724.1 & 0.30 & 17.4 & 0.6 & 1.6 & 0.4 & 16.2 & 63.0 & 126.6 & 237.4 & $7,746.0$ & 6.9 & 7.0 \\
\hline \multicolumn{27}{|c|}{ Sample 14-LM-43 } \\
\hline $43-01.1$ & $2.9 \mathrm{E}-5$ & 58 & 0.0495 & 1.1 & 0.12 & 2.8 & -0.22 & 757 & 281 & 0.0395 & 1.2 & 250 & \pm 3 & 630.5 & 0.01 & 12.8 & 0.1 & 0.7 & 0.1 & 9.5 & 50.0 & 113.7 & 260.7 & $11,135.6$ & 3.2 & 11.6 \\
\hline $43-01.2$ & $1.2 \mathrm{E}-4$ & 71 & 0.0508 & 2.7 & 0.19 & 2.2 & -0.07 & 117 & 64 & 0.0405 & 2.0 & 256 & \pm 5 & 395.7 & 0.02 & 9.4 & 0.2 & 0.8 & 0.2 & 7.0 & 34.4 & 76.2 & 142.9 & $7,929.1$ & 7.2 & 1.3 \\
\hline $43-02.1$ & 2.4E-4 & 38 & 0.0493 & 2.1 & 0.23 & 1.5 & -0.22 & 204 & 141 & 0.0385 & 1.3 & 244 & \pm 3 & 733.5 & 0.02 & 10.6 & 1.9 & 3.5 & 0.5 & 20.9 & 69.5 & 121.0 & 214.3 & $6,124.0$ & 6.9 & 52.6 \\
\hline $43-03.1$ & $-1.3 \mathrm{E}-4$ & 58 & 0.0503 & 2.3 & 0.09 & 2.6 & -0.08 & 171 & 47 & 0.0373 & 2.6 & 236 & \pm 6 & 337.2 & 0.04 & 6.9 & 0.4 & 1.1 & 0.2 & 6.8 & 29.9 & 55.5 & 105.7 & $5,875.8$ & 7.9 & 21.1 \\
\hline 43-04.1 & - & - & 0.0503 & 4.0 & 0.22 & 1.7 & -0.11 & 176 & 124 & 0.0394 & 1.9 & 249 & \pm 5 & 811.4 & 0.04 & 10.6 & 2.0 & 3.7 & 0.7 & 25.1 & 75.6 & 139.3 & 229.1 & $6,600.3$ & 12.0 & 2.6 \\
\hline $43-05.1$ & $9.0 \mathrm{E}-5$ & 58 & 0.0481 & 2.0 & 0.22 & 1.4 & -0.41 & 242 & 169 & 0.0406 & 1.1 & 258 & \pm 3 & $1,063.5$ & 0.05 & 14.2 & 2.1 & 4.0 & 0.7 & 27.0 & 94.4 & 175.0 & 298.6 & $7,105.8$ & 9.8 & 4.0 \\
\hline $43-06.1$ & - & - & 0.0483 & 2.9 & 0.26 & 1.8 & -0.37 & 135 & 104 & 0.0395 & 1.3 & 251 & \pm 3 & 698.5 & 0.25 & 9.4 & 1.6 & 3.5 & 0.6 & 20.3 & 66.6 & 111.6 & 181.3 & $5,668.8$ & 24.8 & 8.1 \\
\hline $43-07.1$ & $1.5 \mathrm{E}-4$ & 50 & 0.0486 & 2.2 & 0.27 & 1.6 & -0.33 & 184 & 152 & 0.0396 & 2.2 & 251 & \pm 6 & 790.8 & 0.01 & 9.6 & 1.7 & 3.1 & 0.6 & 23.9 & 74.8 & 132.2 & 211.2 & $5,628.7$ & 13.4 & 1.7 \\
\hline $43-08.1$ & $-1.7 \mathrm{E}-5$ & 71 & 0.0508 & 1.0 & 0.16 & 1.8 & -0.05 & 880 & 437 & 0.0395 & 1.3 & 250 & \pm 3 & 755.4 & 0.01 & 20.6 & 0.4 & 1.2 & 0.2 & 11.7 & 59.2 & 130.5 & 277.5 & $9,603.0$ & 3.8 & 1.6 \\
\hline $43-09.1$ & $2.5 \mathrm{E}-5$ & 71 & 0.0510 & 1.2 & 0.14 & 1.1 & -0.03 & 612 & 270 & 0.0399 & 1.5 & 253 & \pm 4 & 551.4 & 0.01 & 15.6 & 0.3 & 1.1 & 0.1 & 9.1 & 44.9 & 96.3 & 210.5 & $8,741.2$ & 3.4 & 1.6 \\
\hline $43-09.2$ & $6.6 \mathrm{E}-5$ & 41 & 0.0505 & 1.2 & 0.22 & 0.9 & -0.10 & 659 & 451 & 0.0402 & 1.8 & 254 & \pm 5 & $1,763.1$ & 0.03 & 24.9 & 2.0 & 4.0 & 0.8 & 42.5 & 165.8 & 356.3 & 668.8 & $12,671.7$ & 5.7 & 12.8 \\
\hline $43-10.1$ & - & - & 0.0509 & 2.3 & 0.23 & 1.6 & -0.05 & 180 & 126 & 0.0398 & 1.8 & 252 & \pm 5 & 755.7 & 0.07 & 8.5 & 2.0 & 3.2 & 0.7 & 20.7 & 72.5 & 122.3 & 203.1 & $5,561.2$ & 13.1 & 2.2 \\
\hline $43-11.1$ & $1.6 \mathrm{E}-4$ & 45 & 0.0513 & 2.0 & 0.23 & 1.5 & 0.02 & 228 & 162 & 0.0395 & 2.7 & 250 & \pm 7 & 928.2 & 0.02 & 13.6 & 1.8 & 3.6 & 0.6 & 23.1 & 86.9 & 157.7 & 278.9 & $7,440.3$ & 7.9 & 3.6 \\
\hline $43-12.1$ & $1.2 \mathrm{E}-3$ & 19 & 0.0532 & 2.3 & 0.24 & 3.0 & 0.26 & 169 & 114 & 0.0386 & 0.8 & 244 & \pm 2 & 614.3 & 0.02 & 9.8 & 0.5 & 1.6 & 0.3 & 14.4 & 55.1 & 102.9 & 177.9 & $5,894.7$ & 7.0 & 5.1 \\
\hline $43-13.1$ & $9.1 \mathrm{E}-5$ & 71 & 0.0505 & 4.4 & 0.14 & 5.1 & -0.11 & 174 & 78 & 0.0407 & 2.1 & 257 & \pm 5 & 363.5 & 0.09 & 12.3 & 0.2 & 0.6 & 0.1 & 6.5 & 30.3 & 63.8 & 131.3 & $8,561.1$ & 6.1 & 180.4 \\
\hline $43-14.1$ & - & - & 0.0491 & 1.1 & 0.02 & 2.8 & -0.28 & 802 & 37 & 0.0404 & 1.6 & 256 & \pm 4 & 150.9 & 0.01 & 6.9 & 0.0 & 0.1 & 0.0 & 1.2 & 10.5 & 28.1 & 81.7 & $9,260.6$ & 1.3 & 2.0 \\
\hline $43-15.1$ & 2.0E-4 & 45 & 0.0503 & 5.3 & 0.25 & 1.6 & -0.13 & 178 & 133 & 0.0399 & 1.9 & 253 & \pm 5 & 803.7 & 0.04 & 10.1 & 1.8 & 3.4 & 0.6 & 23.4 & 74.3 & 134.0 & 214.4 & $5,673.1$ & 12.1 & 1.5 \\
\hline $43-16.1$ & $6.2 \mathrm{E}-5$ & 71 & 0.0505 & 2.0 & 0.18 & 1.6 & -0.12 & 219 & 119 & 0.0410 & 1.8 & 259 & \pm 5 & 508.6 & 0.01 & 11.0 & 0.5 & 1.4 & 0.3 & 10.0 & 43.1 & 81.9 & 155.5 & $6,464.7$ & 7.0 & 4.1 \\
\hline $43-17.1$ & $2.3 \mathrm{E}-3$ & 70 & 0.0836 & 13.9 & 0.26 & 9.6 & 4.06 & 206 & 109 & 0.0399 & 3.2 & 242 & \pm 8 & 442.7 & 0.11 & 9.6 & 0.4 & 1.0 & 0.2 & 9.4 & 37.9 & 75.8 & 152.4 & $6,748.6$ & 6.8 & 13.0 \\
\hline $43-18.1$ & $8.9 \mathrm{E}-5$ & 24 & 0.0515 & 0.8 & 0.15 & 0.7 & 0.01 & 1,500 & 671 & 0.0413 & 2.4 & 261 & \pm 6 & 646.7 & 0.10 & 18.8 & 0.4 & 1.0 & 0.2 & 10.0 & 53.1 & 118.9 & 259.4 & $10,110.5$ & 2.6 & 4.7 \\
\hline $43-18.2$ & $6.6 \mathrm{E}-5$ & 100 & 0.0459 & 3.0 & 0.13 & 2.8 & -0.67 & 114 & 42 & 0.0399 & 0.9 & 254 & \pm 2 & 271.9 & 0.01 & 8.1 & 0.2 & 0.6 & 0.1 & 4.5 & 23.9 & 49.9 & 106.0 & $9,036.2$ & 7.1 & 3.2 \\
\hline 43-19.1 & $6.2 \mathrm{E}-5$ & 38 & 0.0490 & 1.1 & 0.16 & 0.9 & -0.29 & 997 & 514 & 0.0400 & 2.1 & 254 & \pm 5 & 1311.2 & 0.00 & 20.3 & & 3.5 & & & 103.0 & & 415.8 & $9,324.9$ & 3.5 & \\
\hline
\end{tabular}


Table 3. SHRIMP-RG U-Pb zircon data for samples analyzed in this report, Lane Mountain area-Continued

[Spot designations indicate sample number, crystal number, and spot number for each zircon analysis. For example, spot 1-01.1 indicates sample 1, crystal 01, and spot 1. Zircon spots highlighted in yellow were statistically rejected from age determinations. Concentrations of Uranium (U), Thorium (Th), Ytrtrium (Y), Lanthanum (La), Cesium (Ce), Neodymium (Nd), Samarium (Sm), Europium (Er), Ytterbium (Yb), Hafnium (Hf), Titanium (Ti), and Iron (Fe) measured in parts per million (ppm)]

\begin{tabular}{|c|c|c|c|c|c|c|c|c|c|c|c|c|c|c|c|c|c|c|c|c|c|c|c|c|c|c|}
\hline Spot & ${ }^{204} \mathrm{~Pb} /{ }^{206} \mathrm{~Pb}$ & $\pm \%$ & ${ }^{207} \mathbf{P b} /{ }^{200} \mathrm{~Pb}$ & $\pm \%$ & ${ }^{2009 b / 2060 ~}$ & $\pm \%$ & $\begin{array}{c}\% \\
{ }^{200 \mathrm{~Pb}_{\mathrm{c}}}\end{array}$ & $\stackrel{\mathrm{ppm}}{\mathrm{U}}$ & $\begin{array}{c}\text { ppm } \\
\text { Th }\end{array}$ & $\begin{array}{c}\text { Total } \\
{ }^{206} \mathrm{~Pb} /{ }^{238} \mathrm{U}\end{array}$ & $\pm \%$ & \multicolumn{2}{|c|}{$\begin{array}{l}{ }^{206 \mathrm{~Pb}} \mathrm{p}^{338 \mathrm{U}} \\
\mathrm{Agg}(\mathrm{Ma})\end{array}$} & $\begin{array}{c}Y \\
\text { (ppm) }\end{array}$ & $\begin{array}{c}\text { La } \\
\text { (ppm) }\end{array}$ & Ce (ppm) & $\begin{array}{c}\mathbf{N d} \\
(\mathrm{ppm})\end{array}$ & $\begin{array}{c}\text { Sm } \\
\text { (ppm) }\end{array}$ & $\begin{array}{c}\text { Eu } \\
\text { (ppm) }\end{array}$ & Gd (ppm) & $\begin{array}{c}\text { Dy } \\
\text { (ppm) }\end{array}$ & $\begin{array}{c}\text { Er } \\
\text { (ppm) }\end{array}$ & $\begin{array}{c}\mathrm{Yb} \\
\text { (ppm) }\end{array}$ & $\begin{array}{c}\text { Hf } \\
\text { (ppm) }\end{array}$ & $\begin{array}{c}\mathrm{Ti} \\
(\mathrm{ppm})\end{array}$ & $\begin{array}{c}\mathrm{Fe} \\
\text { (ppm) }\end{array}$ \\
\hline \multicolumn{27}{|c|}{ Sample 14-LM-43-Continued } \\
\hline $43-20.1$ & $1.5 \mathrm{E}-4$ & 71 & 0.0527 & 3.0 & 0.19 & 2.4 & 0.16 & 105 & 62 & 0.0410 & 2.5 & 258 & \pm 6 & 367.4 & 0.01 & 9.1 & 0.3 & 0.7 & 0.2 & 7.8 & 31.7 & 60.5 & 113.7 & 6,210.6 & 12.8 & 1.9 \\
\hline $43-21.2$ & $3.6 \mathrm{E}-5$ & 100 & 0.0480 & 2.2 & 0.18 & 1.7 & -0.41 & 222 & 120 & 0.0401 & 1.2 & 254 & \pm 3 & 531.4 & 0.01 & 11.7 & 0.2 & 1.2 & 0.2 & 10.1 & 44.7 & 94.3 & 175.1 & $8,183.1$ & 6.6 & 4.9 \\
\hline $43-22.1$ & $3.3 \mathrm{E}-5$ & 71 & 0.0514 & 1.4 & 0.12 & 1.4 & 0.01 & 502 & 190 & 0.0400 & 1.3 & 253 & \pm 3 & 621.3 & 0.01 & 15.4 & 0.2 & 0.8 & 0.1 & 9.5 & 52.4 & 127.8 & 294.1 & $15,928.1$ & 4.2 & 1.5 \\
\hline $43-22.2$ & $2.6 \mathrm{E}-5$ & 45 & 0.0504 & 0.8 & 0.02 & 2.0 & -0.12 & 1,450 & 81 & 0.0401 & 1.2 & 254 & \pm 3 & 318.8 & 0.01 & 11.4 & 0.1 & 0.2 & 0.1 & 3.5 & 23.5 & 72.7 & 219.7 & $19,188.8$ & 1.7 & 2.2 \\
\hline \multicolumn{27}{|c|}{ Sample 14-LM-64 } \\
\hline $64-02.1$ & $1.7 \mathrm{E}-3$ & 19 & 0.0795 & 2.2 & 0.23 & 3.8 & 4.03 & 998 & 424 & 0.0117 & 2.7 & 72.1 & \pm 2 & 790.2 & 38.63 & 169.7 & 29.9 & 15.0 & 10.7 & 46.9 & 87.2 & 118.7 & 232.9 & 12,502 & 10.7 & 414.3 \\
\hline 64-03.1 & $1.8 \mathrm{E}-4$ & 71 & 0.0480 & 3.4 & 0.22 & 4.7 & 0.06 & 691 & 505 & 0.0121 & 4.3 & 77.8 & \pm 3 & 842.7 & 0.03 & 49.8 & 1.4 & 3.1 & 1.6 & 24.7 & 84.4 & 138.4 & 268.8 & 11,867 & 4.2 & 3.0 \\
\hline 64-04.1 & $1.5 \mathrm{E}-4$ & 71 & 0.0442 & 3.2 & 0.20 & 4.5 & -0.45 & 715 & 428 & 0.0135 & 2.4 & 86.9 & \pm 2 & 433.9 & 0.00 & 36.2 & 0.3 & 1.0 & 0.4 & 10.0 & 37.7 & 72.3 & 157.9 & 12,579 & 3.7 & 2.9 \\
\hline $64-05.1$ & 4.0E-4 & 71 & 0.0470 & 5.2 & 0.19 & 7.7 & -0.08 & 272 & 154 & 0.0127 & 5.3 & 81.7 & \pm 4 & 253.0 & 0.00 & 20.8 & 0.2 & 0.7 & 0.3 & 5.8 & 22.8 & 42.7 & 90.1 & 10,738 & 4.9 & 0.9 \\
\hline 64-06.1 & $1.9 \mathrm{E}-4$ & 100 & 0.0495 & 4.9 & 0.16 & 8.3 & 0.23 & 271 & 144 & 0.0128 & 5.8 & 81.7 & \pm 5 & 400.0 & 0.71 & 23.0 & 0.4 & 0.9 & 0.4 & 8.6 & 34.7 & 67.2 & 145.5 & 10,352 & 5.3 & 1.5 \\
\hline $64-07.1$ & $5.6 \mathrm{E}-4$ & 50 & 0.0462 & 4.4 & 0.30 & 5.1 & -0.20 & 296 & 248 & 0.0142 & 3.0 & 91.3 & \pm 3 & 111.4 & 0.00 & 14.5 & 0.1 & 0.2 & 0.1 & 2.7 & 9.1 & 17.7 & 38.9 & 10,229 & 1.8 & 1.6 \\
\hline 64-08.1 & 7.0E-4 & 27 & 0.0639 & 2.3 & 0.33 & 2.9 & 2.07 & 845 & 810 & 0.0110 & 4.9 & 69.0 & \pm 3 & 313.5 & 29.25 & 123.7 & 28.0 & 13.5 & 6.5 & 26.5 & 36.5 & 42.7 & 83.5 & 8,633 & 14.5 & 418.6 \\
\hline $64-09.1$ & $1.3 \mathrm{E}-3$ & 22 & 0.0583 & 2.6 & 0.23 & 3.8 & 1.34 & 1,029 & 586 & 0.0126 & 2.4 & 79.8 & \pm 2 & 838.2 & 9.06 & 99.7 & 12.6 & 8.2 & 5.0 & 28.5 & 80.4 & 132.4 & 249.3 & 10,773 & 14.5 & 201.2 \\
\hline 64-10.1 & $1.3 \mathrm{E}-4$ & 100 & 0.0490 & 4.0 & 0.19 & 6.1 & 0.15 & 501 & 275 & 0.0134 & 1.6 & 85.9 & \pm 1 & 336.8 & 0.01 & 32.6 & 0.3 & 0.9 & 0.4 & 9.1 & 27.9 & 52.2 & 96.9 & 10,425 & 3.3 & 2.1 \\
\hline 64-11.1 & - & - & 0.0458 & 7.1 & 0.23 & 9.5 & -0.24 & 147 & 126 & 0.0126 & 2.8 & 80.8 & \pm 2 & 337.4 & 0.02 & 30.4 & 0.5 & 1.3 & 0.5 & 10.4 & 32.0 & 52.2 & 86.3 & 10,604 & 4.2 & 1.1 \\
\hline 64-13.1 & $2.4 \mathrm{E}-4$ & 33 & 0.0487 & 1.9 & 0.26 & 4.0 & 0.10 & 2,820 & 1820 & 0.0143 & 5.5 & 91.2 & \pm 5 & 353.9 & 6.28 & 57.4 & 3.6 & 2.3 & 1.5 & 12.2 & 32.9 & 53.5 & 116.7 & 11,463 & 11.6 & 46.9 \\
\hline 64-14.1 & $-1.2 \mathrm{E}-4$ & 100 & 0.0531 & 3.9 & 0.13 & 7.1 & 0.69 & 481 & 227 & 0.0129 & 3.5 & 82.3 & \pm 3 & 410.9 & 0.00 & 33.6 & 0.1 & 0.8 & 0.3 & 8.3 & 34.8 & 70.1 & 152.8 & 12,952 & 3.8 & 1.7 \\
\hline 64-15.1 & 4.3E-4 & 41 & 0.0552 & 2.9 & 0.12 & 5.6 & 0.97 & 749 & 261 & 0.0121 & 7.1 & 76.8 & \pm 5 & 320.8 & 3.95 & 48.5 & 4.9 & 3.6 & 2.1 & 11.7 & 28.7 & 50.5 & 116.4 & 11,078 & 5.8 & 29.3 \\
\hline 64-16.1 & 2.3E-3 & 17 & 0.0903 & 2.0 & 0.43 & 2.7 & 5.40 & 1,425 & 1,647 & 0.0121 & 2.2 & 73.2 & \pm 2 & $1,259.2$ & 32.82 & 188.1 & 31.9 & 14.3 & 12.5 & 66.0 & 146.9 & 193.1 & 331.2 & 12,594 & 50.4 & 385.7 \\
\hline $64-17.1$ & $-2.9 \mathrm{E}-4$ & 100 & 0.0451 & 6.3 & 0.30 & 7.4 & -0.32 & 197 & 208 & 0.0124 & 1.8 & 79.8 & \pm 1 & 680.9 & 0.15 & 53.5 & 1.0 & 2.6 & 1.1 & 21.1 & 73.0 & 113.2 & 191.5 & 12,246 & 5.2 & 2.2 \\
\hline 64-18.1 & - & - & 0.0468 & 3.3 & 0.22 & 4.5 & -0.11 & 600 & 412 & 0.0131 & 3.1 & 83.7 & \pm 3 & 737.4 & 0.03 & 42.2 & 0.5 & 1.5 & 0.6 & 16.6 & 67.5 & 127.9 & 268.3 & 11,498 & 5.9 & 3.8 \\
\hline $64-19.1$ & - & - & 0.0464 & 4.5 & 0.33 & 5.1 & -0.14 & 533 & 506 & 0.0111 & 3.8 & 71.3 & \pm 3 & 399.0 & 0.00 & 41.1 & 0.4 & 1.2 & 0.7 & 10.9 & 38.6 & 63.7 & 111.0 & 11,529 & 3.4 & 1.9 \\
\hline $64-20.1$ & $1.7 \mathrm{E}-4$ & 100 & 0.0454 & 4.8 & 0.21 & 6.8 & -0.30 & 314 & 199 & 0.0129 & 5.0 & 83.1 & \pm 4 & 498.5 & 0.41 & 32.7 & 0.6 & 1.6 & 0.7 & 14.3 & 46.2 & 82.0 & 163.6 & 10,267 & 6.0 & 1.9 \\
\hline \multicolumn{27}{|c|}{ Sample 14-LM-154 } \\
\hline $154-01.1$ & $1.6 \mathrm{E}-3$ & 41 & 0.0486 & 5.9 & 0.35 & 4.7 & - & 120 & 101 & 0.0216 & 2.0 & 138 & \pm 3 & 343.6 & 0.08 & 4.1 & 0.7 & 1.0 & 0.9 & 8.5 & 26.8 & 57.5 & 120.9 & $3,511.3$ & 8.8 & 0.3 \\
\hline $154-01.2$ & $2.8 \mathrm{E}-4$ & 41 & 0.0504 & 4.8 & 0.56 & 1.6 & 0.22 & 526 & 790 & 0.0206 & 2.7 & 131 & \pm 4 & $1,049.3$ & 0.12 & 9.2 & 1.1 & 3.3 & 3.3 & 32.8 & 84.9 & 174.7 & 335.7 & $3,532.3$ & 6.6 & 1.3 \\
\hline $154-02.1$ & 8.4E-4 & 58 & 0.0646 & 5.4 & 0.18 & 6.9 & 1.99 & 54 & 23 & 0.0212 & 3.7 & 133 & \pm 5 & 72.7 & 0.03 & 1.9 & 0.1 & 0.1 & 0.1 & 1.2 & 9.8 & 13.3 & 35.1 & $4,094.8$ & 5.2 & 22.0 \\
\hline $154-02.2$ & $-3.8 \mathrm{E}-4$ & 45 & 0.0476 & 3.2 & 0.21 & 3.2 & - & 231 & 139 & 0.0234 & 3.9 & 150 & \pm 6 & 175.5 & 0.01 & 3.5 & 0.2 & 0.5 & 0.4 & 4.0 & 20.6 & 31.6 & 78.0 & $5,467.0$ & 3.7 & 5.0 \\
\hline $154-03.2$ & $3.3 \mathrm{E}-5$ & 100 & 0.0495 & 2.1 & 0.14 & 2.5 & 0.06 & 502 & 207 & 0.0235 & 3.1 & 150 & \pm 5 & 314.2 & 0.01 & 5.8 & 0.1 & 0.4 & 0.4 & 4.0 & 24.8 & 61.5 & 168.2 & $5,163.6$ & 6.1 & 6.5 \\
\hline $154-04.1$ & $-3.8 \mathrm{E}-4$ & 58 & 0.0520 & 4.0 & 0.17 & 8.5 & 0.38 & 133 & 61 & 0.0230 & 3.8 & 146 & \pm 5 & 74.5 & 0.00 & 2.6 & 0.1 & 0.1 & 0.1 & 1.4 & 10.6 & 14.0 & 35.6 & $5,283.9$ & 4.9 & 0.3 \\
\hline $154-05.1$ & $6.4 \mathrm{E}-4$ & 38 & 0.0562 & 3.2 & 0.16 & 4.0 & 0.90 & 210 & 89 & 0.0237 & 3.1 & 150 & \pm 5 & 154.7 & 0.39 & 3.6 & 0.1 & 0.3 & 0.2 & 2.8 & 15.7 & 29.9 & 83.5 & $5,834.4$ & 5.4 & 184.0 \\
\hline $154-06.2$ & - & - & 0.0482 & 2.7 & 0.22 & 2.7 & - & 305 & 202 & 0.0227 & 4.1 & 145 & \pm 6 & 298.2 & 0.04 & 3.9 & 0.6 & 0.9 & 0.8 & 6.7 & 24.2 & 54.7 & 124.7 & $4,367.0$ & 4.7 & 6.1 \\
\hline $154-07.1$ & 4.1E-5 & 100 & 0.0494 & 2.3 & 0.37 & 1.8 & 0.05 & 433 & 481 & 0.0232 & 3.5 & 148 & \pm 5 & 723.5 & 0.17 & 7.3 & 1.0 & 1.9 & 1.8 & 19.1 & 57.6 & 121.5 & 250.2 & $3,986.0$ & 8.8 & 118.3 \\
\hline $154-07.2$ & $1.6 \mathrm{E}-4$ & 71 & 0.0493 & 3.2 & 0.20 & 3.4 & 0.03 & 220 & 125 & 0.0233 & 3.2 & 148 & \pm 5 & 256.7 & 0.05 & 3.5 & 0.7 & 0.9 & 0.7 & 6.2 & 23.0 & 48.4 & 113.4 & $4,624.9$ & 5.8 & 1.9 \\
\hline
\end{tabular}


Table 3. SHRIMP-RG U-Pb zircon data for samples analyzed in this report, Lane Mountain area-Continued

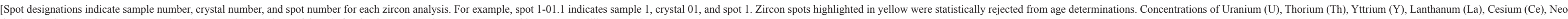
dymium (Nd), Samarium (Sm), Europium (Er), Ytterbium (Yb), Hafnium (Hf), Titanium (Ti), and Iron ( $(\mathrm{Fe})$ measured in parts per million (ppm)]

\begin{tabular}{|c|c|c|c|c|c|c|c|c|c|c|c|c|c|c|c|c|c|c|c|c|c|c|c|c|c|c|}
\hline Spot & ${ }^{204} \mathrm{~Pb} / 206 \mathrm{~Pb}$ & $\pm \%$ & ${ }^{207} \mathrm{~Pb} / 200 \mathrm{~Pb}$ & $\pm \%$ & ${ }^{200} \mathrm{~Pb} /{ }^{206} \mathrm{~Pb}$ & $\pm \%$ & $\begin{array}{c}\% \\
{ }^{200} \mathrm{~Pb}_{\mathrm{c}} \\
\end{array}$ & $\underset{\mathbf{u p m}}{\mathrm{ppm}}$ & $\begin{array}{c}\mathrm{ppm} \\
\mathrm{Th} \\
\end{array}$ & $\begin{array}{c}\text { Total } \\
{ }^{206} \mathrm{~Pb} /{ }^{238} \mathrm{U} \\
\end{array}$ & $\pm \%$ & \multicolumn{2}{|c|}{$\begin{array}{l}{ }^{206} \mathrm{~Pb} /{ }^{238} \mathrm{U} \\
\mathrm{Age}(\mathrm{Ma})\end{array}$} & $\begin{array}{c}Y \\
(p p m)\end{array}$ & $\begin{array}{c}\text { La } \\
\text { (ppm) }\end{array}$ & $\mathrm{Ce}(\mathrm{ppm})$ & $\begin{array}{c}\mathrm{Nd} \\
(\mathrm{ppm})\end{array}$ & $\begin{array}{c}\mathbf{S m} \\
(\mathrm{ppm})\end{array}$ & $\begin{array}{c}\text { Eu } \\
\text { (ppm) }\end{array}$ & Gd (ppm) & $\begin{array}{c}\text { Dy } \\
(\mathrm{ppm})\end{array}$ & $\begin{array}{c}\mathrm{Er} \\
(\mathrm{ppm})\end{array}$ & $\begin{array}{c}\mathrm{Yb} \\
(\mathrm{ppm})\end{array}$ & $\begin{array}{c}\mathrm{Hf} \\
\text { (ppm) }\end{array}$ & $\begin{array}{c}\mathrm{Ti} \\
(\mathrm{ppm})\end{array}$ & $\begin{array}{c}\mathrm{Fe} \\
(\mathrm{ppm})\end{array}$ \\
\hline \multicolumn{27}{|c|}{$\begin{array}{l}\text { Sample 14-LM-490 } \\
\end{array}$} \\
\hline 490_01.1 & $4.0 \mathrm{E}-3$ & 32 & 0.0536 & 7.0 & 0.25 & 7.1 & 0.68 & 227 & 164 & 0.0175 & 2.9 & 111 & \pm 3 & $1,182.1$ & 0.05 & 0.05 & 1.0 & 2.1 & 1.0 & 23.0 & 77.9 & 190.8 & 354.4 & $6,316.0$ & 9.6 & 0.9 \\
\hline 490_02.1 & 4.4E-4 & 71 & 0.0585 & 5.1 & 0.36 & 4.4 & 1.27 & 258 & 245 & 0.0189 & 4.6 & 119 & \pm 5 & $1,321.2$ & 0.20 & 20.6 & 1.9 & 4.1 & 1.7 & 33.1 & 108.0 & 209.7 & 336.9 & $5,151.3$ & 6.4 & 3.0 \\
\hline 490_02.2 & $2.4 \mathrm{E}-3$ & 35 & 0.0593 & 5.8 & 0.27 & 5.9 & 1.34 & 86 & 66 & 0.0205 & 5.1 & 129 & \pm 7 & 774.9 & 0.07 & 10.6 & 1.2 & 2.5 & 0.8 & 20.1 & 69.2 & 128.7 & 223.9 & $5,673.7$ & 10.5 & 2.6 \\
\hline 490_03.1 & - & - & 0.0539 & 4.2 & 0.17 & 9.7 & 0.66 & 153 & 81 & 0.0210 & 2.9 & 133 & \pm 4 & 742.0 & 0.02 & 12.7 & 0.6 & 1.3 & 0.6 & 13.1 & 58.2 & 128.1 & 273.7 & $5,975.8$ & 9.2 & 1.6 \\
\hline $490 \_03.2$ & $6.6 \mathrm{E}-3$ & 16 & 0.0519 & 4.4 & 0.17 & 5.2 & 0.43 & 403 & 129 & 0.0188 & 3.8 & 120 & \pm 5 & 325.2 & 0.46 & 11.6 & 0.2 & 0.5 & 0.2 & 6.3 & 24.6 & 56.8 & 126.3 & $7,762.9$ & 3.8 & 1.3 \\
\hline 490_04.1 & 4.2E-4 & 71 & 0.0508 & 5.1 & 0.28 & 4.7 & 0.26 & 85 & 64 & 0.0210 & 3.3 & 133 & \pm 4 & 913.3 & 0.04 & 9.5 & 1.3 & 2.8 & 0.9 & 23.7 & 82.9 & 159.6 & 279.3 & $5,711.6$ & 13.1 & 0.7 \\
\hline 490_04.2 & $1.4 \mathrm{E}-4$ & 50 & 0.0505 & 2.2 & 0.10 & 7.7 & 0.20 & 794 & 211 & 0.0221 & 2.9 & 141 & \pm 4 & 787.9 & 0.65 & 16.2 & 1.8 & 2.8 & 1.1 & 20.1 & 68.6 & 134.9 & 273.4 & $9,443.9$ & 9.1 & 39.7 \\
\hline 490_05.1 & $1.5 \mathrm{E}-3$ & 35 & 0.0617 & 4.4 & 0.16 & 5.7 & 1.62 & 90 & 37 & 0.0225 & 5.5 & 141 & \pm 8 & 353.9 & 0.10 & 10.2 & 0.2 & 0.7 & 0.2 & 7.3 & 35.7 & 61.1 & 129.1 & $7,348.6$ & 7.8 & 7.0 \\
\hline 490_06.1 & $1.4 \mathrm{E}-3$ & 38 & 0.0526 & 5.0 & 0.18 & 10.6 & 0.47 & 119 & 66 & 0.0220 & 4.0 & 140 & \pm 6 & 549.5 & 0.01 & 14.4 & 0.3 & 0.9 & 0.4 & 10.4 & 46.6 & 93.2 & 187.8 & $6,702.7$ & 8.9 & 2.2 \\
\hline 490_07.1 & $1.3 \mathrm{E}-3$ & 38 & 0.0564 & 10.6 & 0.18 & 5.4 & 0.94 & 90 & 42 & 0.0230 & 4.4 & 145 & \pm 6 & 366.7 & 0.21 & 11.7 & 0.2 & 0.6 & 0.2 & 7.5 & 34.2 & 61.6 & 121.4 & $5,845.8$ & 7.2 & 7.0 \\
\hline 490_08.1 & 8.7E-4 & 45 & 0.0527 & 4.7 & 0.17 & 5.3 & 0.46 & 87 & 41 & 0.0234 & 3.3 & 149 & \pm 5 & 434.5 & 0.01 & 11.6 & 0.3 & 0.9 & 0.3 & 9.0 & 38.2 & 77.9 & 152.6 & $7,387.2$ & 10.7 & 1.5 \\
\hline 490_09.1 & $-3.7 \mathrm{E}-4$ & 71 & 0.0546 & 4.6 & 0.17 & 5.6 & 0.71 & 98 & 46 & 0.0225 & 2.0 & 142 & \pm 3 & 635.8 & 0.01 & 11.0 & 0.5 & 1.3 & 0.5 & 14.1 & 52.6 & 112.5 & 224.2 & $6,559.5$ & 15.3 & 1.1 \\
\hline 490_10.1 & $9.9 \mathrm{E}-4$ & 41 & 0.0525 & 4.5 & 0.24 & 4.4 & 0.43 & 97 & 68 & 0.0242 & 2.9 & 153 & \pm 4 & 875.7 & 0.02 & 15.2 & 1.0 & 2.8 & 0.8 & 23.1 & 76.3 & 149.1 & 267.5 & $7,307.6$ & 12.8 & 1.1 \\
\hline 490_11.1 & $-2.0 \mathrm{E}-4$ & 100 & 0.0527 & 4.9 & 0.18 & 5.6 & 0.45 & 85 & 44 & 0.0241 & 2.8 & 153 & \pm 4 & 497.7 & 0.01 & 12.5 & 0.3 & 1.0 & 0.4 & 11.8 & 43.8 & 87.9 & 174.0 & $7,448.7$ & 12.3 & 0.8 \\
\hline 490_12.1 & $9.2 \mathrm{E}-4$ & 50 & 0.0528 & 5.6 & 0.10 & 9.0 & 0.37 & 182 & 44 & 0.0296 & 3.1 & 188 & \pm 6 & 136.0 & 4.35 & 7.9 & 0.1 & 0.2 & 0.1 & 2.0 & 17.3 & 21.6 & 55.9 & $4,674.9$ & 3.0 & 6.3 \\
\hline 490_13.1 & $1.8 \mathrm{E}-3$ & 35 & 0.0527 & 5.4 & 0.18 & 6.1 & 0.42 & 103 & 48 & 0.0255 & 2.0 & 162 & \pm 3 & 342.1 & 2.55 & 12.5 & 0.2 & 0.7 & 0.2 & 7.1 & 30.4 & 55.2 & 114.1 & $5,492.1$ & 8.4 & 27.5 \\
\hline 490_14.1 & 2.2E-4 & 100 & 0.0549 & 5.0 & 0.23 & 5.2 & 0.74 & 85 & 52 & 0.0237 & 3.9 & 150 & \pm 6 & 724.7 & 0.02 & 12.0 & 0.9 & 2.2 & 0.7 & 18.9 & 62.0 & 126.0 & 232.7 & $7,480.1$ & 13.2 & 6.2 \\
\hline 490_15.1 & $1.3 \mathrm{E}-3$ & 38 & 0.0528 & 4.7 & 0.13 & 6.4 & 0.46 & 93 & 32 & 0.0244 & 2.0 & 154 & \pm 3 & 282.1 & 0.03 & 8.3 & 0.1 & 0.4 & 0.2 & 4.3 & 30.9 & 51.3 & 124.2 & $9,136.0$ & 6.2 & 4.9 \\
\hline $490 \_18.1$ & $2.5 \mathrm{E}-3$ & 20 & 0.0701 & 20.2 & 0.16 & 19.7 & 2.65 & 155 & 50 & 0.0238 & 6.4 & 148 & \pm 10 & 129.0 & 0.46 & 5.5 & 0.1 & 0.2 & 0.1 & 1.8 & 13.9 & 23.1 & 67.4 & $6,362.6$ & 4.9 & 28.5 \\
\hline 490_19.1 & - & - & 0.0540 & 5.5 & 0.27 & 5.3 & 0.62 & 62 & 52 & 0.0238 & 2.1 & 150 & \pm 3 & 852.4 & 0.01 & 13.1 & 0.8 & 2.4 & 0.9 & 23.8 & 77.3 & 144.3 & 250.3 & $6,748.0$ & 17.5 & 0.6 \\
\hline 490_20.1 & $1.4 \mathrm{E}-3$ & 38 & 0.0521 & 4.9 & 0.22 & 5.1 & 0.38 & 80 & 51 & 0.0237 & 3.9 & 150 & \pm 6 & 547.6 & 0.01 & 14.6 & 0.5 & 1.3 & 0.5 & 13.2 & 48.7 & 95.7 & 184.1 & $6,862.7$ & 17.3 & 0.5 \\
\hline 490_21.1 & $5.4 \mathrm{E}-4$ & 58 & 0.0518 & 4.8 & 0.26 & 4.4 & 0.38 & 100 & 67 & 0.0217 & 3.3 & 138 & \pm 5 & 705.6 & 0.21 & 11.6 & 1.0 & 2.3 & 0.8 & 19.6 & 58.6 & 112.9 & 196.0 & $4,852.7$ & 7.4 & 8.7 \\
\hline 490_22.1 & $6.0 \mathrm{E}-4$ & 58 & 0.0535 & 4.9 & 0.23 & 5.1 & 0.54 & 97 & 64 & 0.0243 & 2.4 & 154 & \pm 4 & 893.4 & 0.40 & 13.5 & 1.0 & 2.8 & 0.9 & 24.2 & 79.9 & 154.5 & 272.9 & $7,889.3$ & 12.8 & 3.9 \\
\hline \multicolumn{27}{|c|}{ Sample 15-LM-1076 } \\
\hline $\begin{array}{ll}1076-01.1 \\
\end{array}$ & $-1.0 \mathrm{E}-4$ & 100 & 0.0454 & 3.8 & 0.18 & 9.2 & $\begin{array}{l}-0.28 \\
\end{array}$ & 454 & 302 & 0.0122 & 3.6 & 78.7 & \pm 3 & 355.7 & 0.17 & 35.1 & 0.4 & 0.9 & 0.5 & 10.3 & 33.8 & 60.8 & 125.6 & $11,823.2$ & 3.1 & 4.5 \\
\hline $1076-02.1$ & $1.9 \mathrm{E}-4$ & 100 & 0.0460 & 5.0 & 0.13 & 8.8 & -0.22 & 282 & 122 & 0.0129 & 3.4 & 83.0 & \pm 3 & 207.7 & 0.01 & 15.2 & 0.1 & 0.2 & 0.2 & 3.4 & 16.0 & 35.5 & 85.3 & $11,478.4$ & 2.1 & 1.6 \\
\hline $1076-03.1$ & - & - & 0.0471 & 3.8 & 0.19 & 5.7 & -0.08 & 500 & 288 & 0.0133 & 2.3 & 85.2 & \pm 2 & 296.6 & 0.01 & 23.1 & 0.2 & 0.6 & 0.4 & 7.4 & 27.9 & 49.4 & 108.9 & $12,617.2$ & 2.4 & 3.1 \\
\hline $1076-04.1$ & $-3.5 \mathrm{E}-4$ & 71 & 0.0452 & 5.0 & 0.12 & 9.3 & -0.33 & 223 & 112 & 0.0137 & 1.7 & 87.7 & \pm 2 & 600.0 & 0.01 & 16.7 & 0.6 & 1.7 & 0.6 & 17.2 & 61.1 & 96.4 & 149.2 & $8,763.4$ & 8.2 & 1.1 \\
\hline $1076-05.1$ & $5.4 \mathrm{E}-4$ & 58 & 0.0464 & 4.9 & 0.18 & 7.5 & -0.17 & 285 & 166 & 0.0133 & 1.7 & 85.1 & \pm 1 & 727.3 & 0.02 & 41.8 & 0.5 & 1.9 & 1.2 & 21.6 & 71.0 & 113.4 & 208.6 & $9,677.8$ & 3.1 & 2.5 \\
\hline $1076-06.1$ & - & - & 0.0430 & 4.9 & 0.11 & 9.2 & -0.60 & 335 & 145 & 0.0135 & 4.3 & 86.7 & \pm 4 & 252.9 & 0.01 & 16.8 & 0.1 & 0.3 & 0.3 & 3.7 & 18.4 & 43.0 & 113.7 & $12,217.0$ & 2.4 & 1.3 \\
\hline $1076-07.1$ & - & 100 & 0.0443 & 4.7 & 0.13 & 8.2 & -0.44 & 300 & 121 & 0.0136 & 2.3 & 87.4 & \pm 2 & 212.3 & 0.02 & 13.5 & 0.1 & 0.3 & 0.2 & 3.2 & 14.9 & 35.6 & 98.7 & $9,112.2$ & 2.4 & 1.4 \\
\hline $1076-08.1$ & - & - & 0.0498 & 3.6 & 0.17 & 5.6 & 0.26 & 570 & 320 & 0.0131 & 2.5 & 83.4 & \pm 2 & 701.0 & 0.01 & 46.6 & 0.4 & 1.3 & 0.7 & 13.5 & 61.4 & 120.2 & 244.8 & $11,794.0$ & 3.9 & 2.3 \\
\hline $1076-09.1$ & $1.3 \mathrm{E}-4$ & 100 & 0.0490 & 4.5 & 0.17 & 6.5 & 0.17 & 422 & 207 & 0.0128 & 1.9 & 81.7 & \pm 2 & 522.2 & 0.02 & 34.7 & 0.3 & 1.2 & 0.6 & 10.9 & 47.2 & 88.6 & 190.4 & $11,616.2$ & 3.2 & 2.5 \\
\hline $1076-10.1$ & $-1.6 \mathrm{E}-4$ & 100 & 0.0488 & 4.5 & 0.14 & 8.1 & 0.14 & 286 & 122 & 0.0129 & 2.3 & 82.7 & \pm 2 & 164.3 & 0.08 & 13.8 & 0.2 & 0.2 & 0.2 & 2.2 & 11.8 & 28.9 & 78.6 & $10,770.2$ & 2.0 & 2.1 \\
\hline $1076-11.1$ & $1.4 \mathrm{E}-4$ & 100 & 0.0497 & 4.2 & 0.19 & 15.0 & 0.24 & 398 & 234 & 0.0140 & 1.8 & 89.2 & \pm 2 & 562.4 & 0.73 & 27.6 & 0.9 & 1.8 & 0.8 & 15.4 & 50.6 & 92.1 & 193.7 & $10,106.0$ & 4.3 & 2.7 \\
\hline $1076-12.1$ & - & - & 0.0477 & 3.3 & 0.31 & 3.8 & 0.00 & 566 & 487 & 0.0132 & 2.3 & 84.7 & \pm 2 & 213.7 & 0.01 & 22.1 & 0.4 & 0.5 & 0.4 & 6.1 & 19.4 & 36.7 & 80.0 & $11,770.9$ & 2.2 & 3.3 \\
\hline
\end{tabular}


Table 3. SHRIMP-RG U-Pb zircon data for samples analyzed in this report, Lane Mountain area-Continued

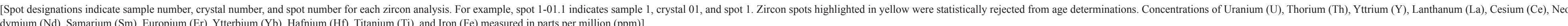

\begin{tabular}{|c|c|c|c|c|c|c|c|c|c|c|c|c|c|c|c|c|c|c|c|c|c|c|c|c|c|c|}
\hline Spot & $204 \mathrm{~Pb} / 200 \mathrm{~Pb}$ & $\pm \%$ & ${ }^{207} \mathrm{~Pb} / 200 \mathrm{~Pb}$ & $\pm \%$ & $208 \mathrm{~Pb} / 200 \mathrm{~Pb}$ & $\pm \%$ & $\begin{array}{c}\% \\
200 \mathrm{~Pb}_{\mathrm{c}}\end{array}$ & $\begin{array}{c}\mathrm{ppm} \\
\mathbf{U}\end{array}$ & $\begin{array}{c}\mathrm{ppm} \\
\mathrm{Th}\end{array}$ & 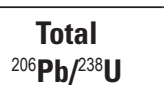 & $\pm \%$ & \multicolumn{2}{|c|}{$\begin{array}{l}{ }^{200 \mathrm{~Pb}}{ }^{2338} \mathrm{U} \\
\mathrm{Age}(\mathrm{Ma})\end{array}$} & $\begin{array}{c}\mathrm{Y} \\
(\mathrm{ppm})\end{array}$ & $\begin{array}{c}\text { La } \\
(\mathrm{ppm})\end{array}$ & Ce (ppm) & $\begin{array}{c}\mathrm{Nd} \\
(\mathrm{ppm})\end{array}$ & $\begin{array}{c}\mathrm{Sm} \\
(\mathrm{ppm})\end{array}$ & $\begin{array}{c}\text { Eu } \\
\text { (ppm) }\end{array}$ & Gd (ppm) & $\begin{array}{c}\mathrm{Dy} \\
(\mathrm{ppm})\end{array}$ & $\begin{array}{c}\mathrm{Er} \\
(\mathrm{ppm})\end{array}$ & $\begin{array}{c}\mathbf{Y b} \\
(\mathrm{ppm})\end{array}$ & $\begin{array}{c}\mathrm{Hf} \\
(\mathrm{ppm})\end{array}$ & $\begin{array}{c}\mathrm{Ti} \\
(\mathrm{ppm})\end{array}$ & $\begin{array}{c}\mathrm{Fe} \\
\text { (ppm) }\end{array}$ \\
\hline \multicolumn{27}{|c|}{ Sample 15-LM-1076-Continued } \\
\hline $1076-13.1$ & $-3.7 \mathrm{E}-4$ & 100 & 0.0428 & 7.5 & 0.12 & 13.1 & -0.62 & 140 & 61 & 0.0133 & 1.8 & 85.6 & \pm 2 & 339.7 & 0.01 & 19.5 & 0.3 & 0.9 & 0.4 & 8.3 & 30.9 & 54.5 & 115.1 & $10,367.1$ & 2.6 & 1.0 \\
\hline $1076-14.1$ & $1.3 \mathrm{E}-4$ & 100 & 0.0480 & 4.1 & 0.11 & 20.0 & 0.04 & 388 & 166 & 0.0131 & 4.7 & 83.7 & \pm 4 & 255.1 & 0.03 & 17.1 & 0.3 & 0.6 & 0.3 & 6.6 & 22.9 & 37.8 & 75.4 & $10,825.5$ & 1.8 & 3.2 \\
\hline $1076-15.1$ & - & 100 & 0.0467 & 4.4 & 0.16 & 7.2 & -0.13 & 300 & 134 & 0.0131 & 2.5 & 83.7 & \pm 2 & 232.9 & 0.01 & 13.6 & 0.1 & 0.4 & 0.3 & 5.0 & 18.7 & 36.2 & 83.6 & $8,825.2$ & 1.6 & 1.5 \\
\hline $1076-16.1$ & $-9.7 \mathrm{E}-5$ & 100 & 0.0493 & 3.5 & 0.16 & 5.9 & 0.20 & 542 & 302 & 0.0136 & 2.0 & 86.7 & \pm 2 & 412.5 & 0.01 & 24.7 & 0.4 & 1.1 & 0.4 & 11.3 & 38.8 & 65.7 & 122.9 & $10,660.6$ & 2.2 & 2.5 \\
\hline $1076-17.1$ & $1.5 \mathrm{E}-4$ & 100 & 0.0497 & 4.4 & 0.13 & 8.3 & 0.24 & 308 & 137 & 0.0134 & 1.7 & 85.8 & \pm 1 & 243.0 & 0.00 & 15.7 & 0.2 & 0.5 & 0.3 & 4.9 & 20.0 & 40.3 & 95.7 & $10,012.5$ & 1.8 & 1.5 \\
\hline $1076-18.1$ & $3.6 \mathrm{E}-4$ & 71 & 0.0463 & 4.9 & 0.20 & 6.9 & -0.18 & 196 & 139 & 0.0135 & 4.3 & 86.3 & \pm 4 & 211.9 & 0.00 & 15.8 & 0.1 & 0.5 & 0.3 & 5.6 & 18.6 & 33.9 & 71.8 & $9,462.6$ & 2.2 & 1.4 \\
\hline $1076-19.1$ & - & 100 & 0.0454 & 4.2 & 0.14 & 18.9 & -0.30 & 352 & 154 & 0.0135 & 3.4 & 86.7 & \pm 3 & 303.3 & 0.00 & 14.4 & 0.1 & 0.5 & 0.3 & 5.6 & 24.1 & 48.9 & 109.3 & $9,701.3$ & 2.0 & 1.9 \\
\hline $1076-20.1$ & - & 100 & 0.0536 & 3.9 & 0.17 & 6.7 & 0.75 & 425 & 224 & 0.0127 & 2.7 & 80.5 & \pm 2 & 251.5 & 0.14 & 20.5 & 0.2 & 0.6 & 0.3 & 5.4 & 20.8 & 40.0 & 92.1 & $8,657.9$ & 2.2 & 2.9 \\
\hline \multicolumn{27}{|c|}{ Sample 15-LM-1124 } \\
\hline $1124-01.1$ & - & 100 & 0.0405 & 9.6 & 0.20 & 13.5 & -0.90 & 94 & 63 & 0.0128 & 3.1 & 82.8 & \pm 3 & 203.8 & 0.01 & 20.0 & 0.2 & 0.5 & 0.3 & 5.9 & 19.8 & 34.0 & 65.9 & $10,131.4$ & 4.2 & 0.4 \\
\hline $1124-02.1$ & - & - & 0.0483 & 3.9 & 0.13 & 7.0 & 0.07 & 484 & 227 & 0.0134 & 2.3 & 86.0 & \pm 2 & 637.9 & 0.02 & 30.6 & 0.4 & 1.3 & 0.8 & 14.3 & 54.7 & 100.2 & 184.6 & $10,916.2$ & 2.5 & 2.7 \\
\hline $1124-03.1$ & - & - & 0.0369 & 11.0 & 0.24 & 12.7 & -1.35 & 84 & 75 & 0.0120 & 3.3 & 78.0 & \pm 3 & 546.4 & 0.01 & 18.0 & 0.8 & 1.9 & 0.8 & 14.9 & 52.7 & 96.6 & 196.6 & $9,734.0$ & 6.4 & 0.3 \\
\hline $1124-04.1$ & $-7.0 \mathrm{E}-4$ & 100 & 0.0469 & 10.0 & 0.14 & 16.8 & -0.09 & 80 & 37 & 0.0121 & 1.9 & 77.8 & \pm 2 & 224.5 & 0.01 & 12.9 & 0.4 & 1.0 & 0.5 & 7.6 & 21.3 & 35.9 & 62.8 & $9,962.6$ & 4.8 & 1.7 \\
\hline $1124-05.1$ & - & 100 & 0.0385 & 8.6 & 0.10 & 16.6 & -1.14 & 135 & 50 & 0.0119 & 2.9 & 77.3 & \pm 2 & 396.7 & 0.01 & 11.2 & 0.4 & 1.4 & 0.6 & 12.5 & 41.6 & 65.8 & 114.3 & $10,595.8$ & 4.2 & 0.1 \\
\hline $1124-06.1$ & $3.8 \mathrm{E}-3$ & 71 & 0.0527 & 15.8 & 0.27 & 19.2 & 0.67 & 25 & 22 & 0.0105 & 5.7 & 66.7 & \pm 4 & 186.8 & 0.01 & 8.5 & 0.2 & 0.7 & 0.3 & 5.6 & 18.4 & 29.5 & 52.2 & $8,585.0$ & 6.8 & 3.4 \\
\hline $1124-07.1$ & 7.1E-5 & 100 & 0.0696 & 2.9 & 0.20 & 7.9 & -0.73 & 52 & 33 & 0.1821 & 8.1 & 1,086 & \pm 85 & 385.6 & 0.00 & 9.1 & 0.2 & 0.8 & 0.1 & 9.1 & 39.4 & 76.1 & 122.1 & $11,134.5$ & 8.4 & 0.2 \\
\hline $1124-08.1$ & - & 100 & 0.0439 & 5.5 & 0.24 & 7.0 & -0.68 & 115 & 90 & 0.0254 & 2.9 & 163 & \pm 5 & 474.1 & 0.03 & 24.6 & 0.3 & 0.8 & 0.3 & 10.1 & 40.5 & 82.2 & 168.8 & $9,389.0$ & 6.8 & 0.6 \\
\hline $1124-09.1$ & $-3.5 \mathrm{E}-4$ & 58 & 0.0473 & 3.9 & 0.20 & 5.6 & -0.22 & 243 & 150 & 0.0233 & 2.1 & 149 & \pm 3 & 631.7 & 0.01 & 29.7 & 0.3 & 1.0 & 0.3 & 10.6 & 55.4 & 116.3 & 242.0 & $12,297.7$ & 6.2 & 0.8 \\
\hline $1124-11.1$ & $1.9 \mathrm{E}-3$ & 71 & 0.0458 & 11.8 & 0.25 & 15.2 & -0.22 & 51 & 48 & 0.0118 & 3.0 & 76.0 & \pm 2 & 562.6 & 0.06 & 9.6 & 2.7 & 4.4 & 2.5 & 30.8 & 69.6 & 79.5 & 103.2 & $7,452.8$ & 10.1 & 0.1 \\
\hline $1124-12.1$ & - & 100 & 0.0594 & 16.1 & 0.35 & 17.9 & 1.49 & 28 & 27 & 0.0123 & 2.2 & 77.4 & \pm 2 & 357.2 & 0.05 & 11.0 & 1.9 & 3.3 & 2.2 & 22.1 & 45.4 & 53.0 & 70.0 & $6,987.7$ & 10.5 & 0.4 \\
\hline $1124-13.1$ & $1.0 \mathrm{E}-3$ & 71 & 0.0517 & 8.1 & 0.12 & 15.9 & 0.50 & 100 & 54 & 0.0136 & 1.8 & 86.6 & \pm 2 & 515.7 & 0.01 & 22.4 & 0.8 & 2.0 & 1.1 & 16.8 & 47.4 & 86.7 & 164.4 & $8,268.0$ & 6.2 & 0.2 \\
\hline $1124-14.1$ & $-5.1 \mathrm{E}-4$ & 100 & 0.0492 & 8.2 & 0.18 & 12.5 & 0.21 & 111 & 54 & 0.0114 & 7.1 & 72.7 & \pm 5 & 223.6 & 0.01 & 13.7 & 0.2 & 0.5 & 0.3 & 5.5 & 19.6 & 37.6 & 81.4 & $9,961.3$ & 3.9 & 0.3 \\
\hline $1124-15.1$ & - & 100 & 0.0476 & 17.6 & 0.31 & 9.5 & 0.01 & 107 & 106 & 0.0117 & 4.5 & 74.9 & \pm 3 & 978.7 & 0.01 & 13.5 & 1.4 & 4.2 & 2.0 & 34.2 & 113.7 & 151.2 & 213.6 & $9,005.5$ & 15.0 & 1.0 \\
\hline $1124-16.1$ & - & 100 & 0.0452 & 8.8 & 0.14 & 14.8 & -0.30 & 100 & 48 & 0.0119 & 3.3 & 76.5 & \pm 3 & 589.9 & 0.01 & 17.7 & 0.9 & 1.9 & 1.1 & 16.7 & 55.6 & 106.5 & 194.7 & $9,901.8$ & 8.5 & 0.1 \\
\hline $1124-17.1$ & - & - & 0.0495 & 4.7 & 0.18 & 7.4 & 0.21 & 283 & 150 & 0.0140 & 3.5 & 89.1 & \pm 3 & 430.3 & 0.01 & 20.7 & 0.3 & 1.1 & 0.3 & 8.3 & 35.4 & 75.4 & 163.8 & $10,136.8$ & 6.4 & 0.3 \\
\hline $1124-18.1$ & - & - & 0.0544 & 6.8 & 0.18 & 11.1 & 0.86 & 148 & 96 & 0.0122 & 2.4 & 77.2 & \pm 2 & 501.5 & 0.01 & 18.7 & 1.0 & 2.3 & 1.0 & 17.1 & 52.0 & 81.0 & 146.3 & $9,235.5$ & 4.6 & 0.7 \\
\hline $1124-19.1$ & $5.7 \mathrm{E}-4$ & 71 & 0.0479 & 6.2 & 0.19 & 9.4 & 0.02 & 191 & 118 & 0.0134 & 3.1 & 85.7 & \pm 3 & 467.0 & 0.00 & 9.2 & 0.6 & 1.5 & 0.5 & 13.7 & 44.5 & 77.1 & 157.5 & $9,332.7$ & 7.0 & 0.1 \\
\hline $1124-20.1$ & $1.4 \mathrm{E}-3$ & 100 & 0.0431 & 14.2 & 0.25 & 18.8 & -0.56 & 39 & 29 & 0.0119 & 3.6 & 76.6 & \pm 3 & 329.0 & 0.01 & 10.5 & 0.5 & 1.2 & 0.8 & 9.8 & 31.8 & 51.3 & 87.8 & $7,670.4$ & 6.9 & 0.7 \\
\hline \multicolumn{27}{|c|}{ Sample 16-LM-1301 } \\
\hline $1301-02.1$ & - & - & 0.0499 & 10.5 & 0.435 & 10.6 & 0.294 & 56 & 62 & 0.012 & 5.3 & 75.9 & \pm 4 & 334.3 & 0.06 & 15.4 & 2.6 & 4.4 & 2.4 & 22.1 & 41.8 & 43.3 & 67.5 & $7,967.3$ & 10.5 & 3.2 \\
\hline $1301-03.1$ & $2.1 \mathrm{E}-4$ & 100 & 0.0509 & 5.1 & 0.200 & 7.8 & 0.229 & 101 & 61 & 0.024 & 1.9 & 154 & \pm 3 & 812.0 & 0.01 & 21.1 & 0.4 & 1.5 & 1.1 & 15.9 & 67.8 & 144.5 & 289.1 & $8,665.6$ & 5.1 & 2.0 \\
\hline $1301-04.1$ & - & 100 & 0.0461 & 4.1 & 0.076 & 10.6 & -0.189 & 344 & 75 & 0.012 & 2.8 & 80.1 & \pm 2 & 443.9 & 0.00 & 7.4 & 0.2 & 0.9 & 0.3 & 8.1 & 37.6 & 77.8 & 171.8 & $11,264.7$ & 2.8 & 3.0 \\
\hline $1301-04.2$ & $2.5 \mathrm{E}-4$ & 71 & 0.0458 & 4.1 & 0.052 & 12.1 & -0.230 & 384 & 81 & 0.013 & 2.0 & 82.0 & \pm 2 & 429.9 & 0.01 & 6.8 & 0.2 & 0.9 & 0.3 & 9.6 & 40.7 & 75.6 & 167.1 & $11,584.7$ & 2.8 & 1.2 \\
\hline $1301-05.1$ & $-1.0 \mathrm{E}-3$ & 100 & 0.0511 & 12.0 & 0.111 & 21.7 & 0.440 & 47 & 27 & 0.013 & 3.5 & 80.6 & \pm 3 & 373.1 & 0.01 & 11.2 & 0.3 & 0.8 & 0.5 & 6.4 & 30.2 & 69.9 & 177.4 & $9,467.1$ & 3.7 & 0.8 \\
\hline 1301-06.1 & $1.2 \mathrm{E}-4$ & 100 & 0.0472 & 4.0 & 0.107 & 13.7 & -0.061 & 393 & 142 & 0.013 & 2.9 & 81.2 & \pm 2 & 514.7 & 0.00 & 21.3 & 0.2 & 0.8 & 0.6 & 10.8 & 41.6 & 84.4 & 203.9 & $11,932.4$ & 2.0 & 4.7 \\
\hline $1301-07.1$ & - & 100 & 0.0433 & 10.3 & 0.212 & 14.2 & -0.528 & 55 & 35 & 0.012 & 5.2 & 75.8 & \pm 4 & 728.4 & 0.01 & 12.5 & 1.1 & 2.4 & 1.4 & 18.8 & 69.9 & 118.2 & 208.0 & $8,855.4$ & 13.4 & 0.6 \\
\hline 301-08. & $.8 \mathrm{E}-4$ & 100 & 0.0489 & 4.8 & 0.128 & 16.0 & 0.096 & 193 & 77 & 0.016 & 2.0 & 104 & \pm 2 & 636.9 & 0.00 & 19.1 & 0.3 & 1.1 & 0.5 & 11.3 & 55.6 & 116.9 & 266.9 & $2,034.6$ & 5.5 & 3 \\
\hline
\end{tabular}


Table 3. SHRIMP-RG U-Pb zircon data for samples analyzed in this report, Lane Mountain area-Continued

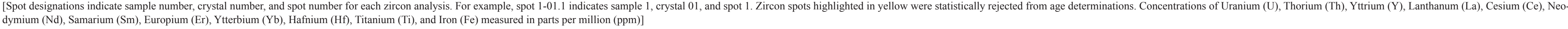

\begin{tabular}{|c|c|c|c|c|c|c|c|c|c|c|c|c|c|c|c|c|c|c|c|c|c|c|c|c|c|c|}
\hline Spot & ${ }^{204} \mathrm{~Pb} / 20 \mathrm{~Pb}$ & $\pm \%$ & ${ }^{207} \mathbf{P b} / 20 \mathrm{~Pb}$ & $\pm \%$ & ${ }^{200 \mathrm{~Pb} / 20 \mathrm{~Pb}}$ & $\pm \%$ & $\begin{array}{c}\% \\
2006 \mathrm{ph}_{\mathrm{c}}\end{array}$ & $\underset{U}{\mathrm{ppm}}$ & $\begin{array}{c}\text { ppm } \\
\text { Th }\end{array}$ & $\begin{array}{c}\text { Total } \\
{ }^{200} \mathrm{~Pb} /{ }^{238} \mathrm{U}\end{array}$ & $\pm \%$ & \multicolumn{2}{|c|}{$\begin{array}{l}{ }^{200} \mathrm{~Pb} /{ }^{238} \mathrm{U} \\
\mathrm{Age}(\mathrm{Ma})\end{array}$} & $\begin{array}{c}\mathrm{Y} \\
(\mathrm{ppm})\end{array}$ & $\begin{array}{c}\text { La } \\
(\mathrm{ppm})\end{array}$ & Ce (ppm) & $\begin{array}{c}\mathrm{Nd} \\
(\mathrm{ppm})\end{array}$ & $\begin{array}{c}\mathrm{Sm} \\
(\mathrm{ppm})\end{array}$ & $\begin{array}{c}\text { Eu } \\
\text { (ppm) }\end{array}$ & Gd (ppm) & $\begin{array}{c}\mathrm{Dy} \\
(\mathrm{ppm})\end{array}$ & $\begin{array}{c}\mathrm{Er} \\
\text { (ppm) }\end{array}$ & $\begin{array}{c}\mathbf{Y b} \\
(\mathrm{ppm})\end{array}$ & $\begin{array}{c}\mathrm{Hf} \\
(\mathrm{ppm})\end{array}$ & $\begin{array}{c}\mathrm{Ti} \\
(\mathrm{ppm})\end{array}$ & $\begin{array}{c}\mathrm{Fe} \\
(\mathrm{ppm})\end{array}$ \\
\hline \multicolumn{27}{|c|}{ Sample 16-LM-1301-Continued } \\
\hline $1301-09.1$ & $-2.3 \mathrm{E}-4$ & 100 & 0.0405 & 6.2 & 0.236 & 16.7 & -0.909 & 194 & 163 & 0.013 & 2.7 & 83.8 & \pm 2 & 870.2 & 0.02 & 34.0 & 2.8 & 5.9 & 2.8 & 36.0 & 94.1 & 136.0 & 230.2 & $10,040.9$ & 4.2 & 2.2 \\
\hline $1301-10.1$ & $1.0 \mathrm{E}-3$ & 71 & 0.0457 & 8.7 & 0.132 & 15.7 & -0.243 & 98 & 50 & 0.013 & 2.8 & 81.2 & \pm 2 & 431.0 & 0.00 & 14.2 & 0.5 & 1.6 & 0.7 & 12.2 & 42.2 & 74.3 & 148.3 & $11,225.4$ & 4.3 & 1.0 \\
\hline 1301-11.1 & - & - & 0.0514 & 5.6 & 0.182 & 8.7 & 0.477 & 204 & 106 & 0.012 & 4.4 & 77.8 & \pm 3 & 339.2 & 0.01 & 25.2 & 0.3 & 1.0 & 0.5 & 8.2 & 30.5 & 55.7 & 127.3 & $10,790.1$ & 3.6 & 2.2 \\
\hline $1301-12.1$ & $-3.2 \mathrm{E}-3$ & 71 & 0.0454 & 15.6 & 0.381 & 16.0 & -0.278 & 31 & 38 & 0.012 & 3.2 & 78.6 & \pm 3 & 671.5 & 0.11 & 25.3 & 5.1 & 8.6 & 5.0 & 46.4 & 92.5 & 97.5 & 139.4 & $7,940.4$ & 14.1 & 6.0 \\
\hline $1301-13.1$ & $1.8 \mathrm{E}-4$ & 58 & 0.0482 & 4.9 & 0.378 & 7.1 & -0.100 & 414 & 443 & 0.023 & 2.4 & 149 & \pm 4 & $1,263.0$ & 0.03 & 63.6 & 1.2 & 2.1 & 1.2 & 22.3 & 99.1 & 226.2 & 577.6 & $11,498.5$ & 4.9 & 2.9 \\
\hline $1301-14.1$ & $-1.4 \mathrm{E}-4$ & 100 & 0.0444 & 4.5 & 0.071 & 10.6 & -0.402 & 343 & 85 & 0.012 & 2.0 & 79.4 & \pm 2 & 370.7 & 0.00 & 10.8 & 0.1 & 0.5 & 0.4 & 6.1 & 29.5 & 63.0 & 154.7 & $14,466.0$ & 1.3 & 4.3 \\
\hline $1301-15.1$ & - & - & 0.0488 & 2.9 & 0.190 & 4.4 & -0.068 & 374 & 218 & 0.026 & 2.3 & 164 & \pm 4 & 759.3 & 0.01 & 39.6 & 0.3 & 1.1 & 0.2 & 12.7 & 66.1 & 147.1 & 336.6 & $11,935.4$ & 5.1 & 2.0 \\
\hline $1301-16.1$ & $2.5 \mathrm{E}-4$ & 58 & 0.0474 & 3.4 & 0.082 & 13.4 & -0.069 & 415 & 73 & 0.015 & 2.2 & 95.4 & \pm 2 & 722.8 & 0.01 & 38.3 & 0.3 & 1.0 & 0.4 & 11.9 & 60.2 & 136.9 & 314.3 & $11,460.0$ & 3.5 & 2.4 \\
\hline $1301-18.1$ & $3.8 \mathrm{E}-5$ & 100 & 0.0506 & 2.1 & 0.692 & 1.8 & 0.179 & 609 & 1199 & 0.025 & 2.4 & 156 & \pm 4 & $4,120.8$ & 0.17 & 339.6 & 10.4 & 19.6 & 8.2 & 136.0 & 441.8 & 703.9 & $1,173.7$ & $8,086.2$ & 8.4 & 12.8 \\
\hline \multicolumn{27}{|c|}{ Sample 16-LM-1304 } \\
\hline 1304-01.1 & $1.1 \mathrm{E}-3$ & 71 & 0.0399 & 8.0 & 0.157 & 13.6 & -0.827 & 352 & 176 & 0.004 & 2.3 & 22.8 & \pm 0.5 & $1,484.5$ & 0.08 & 6.4 & 2.3 & 2.6 & 0.8 & 48.0 & 167.1 & 261.0 & 433.3 & $10,063.7$ & 7.3 & 35.6 \\
\hline $1304-02.1$ & $3.1 \mathrm{E}-4$ & 71 & 0.0480 & 9.4 & 0.088 & 10.0 & 0.194 & 1196 & 327 & 0.003 & 2.4 & 22.3 & \pm 0.6 & $2,765.8$ & 0.01 & 7.4 & 1.4 & 5.4 & 1.0 & 62.1 & 273.7 & 477.1 & 754.6 & $11,082.4$ & 1.9 & 2.9 \\
\hline $1304-03.1$ & $9.1 \mathrm{E}-4$ & 38 & 0.0490 & 3.5 & 0.136 & 7.2 & 0.326 & 1416 & 589 & 0.003 & 2.2 & 22.0 & \pm 0.5 & $3,191.8$ & 0.16 & 20.0 & 3.3 & 8.3 & 1.5 & 81.9 & 327.2 & 548.0 & 951.1 & $8,868.8$ & 2.8 & 9.2 \\
\hline $1304-04.1$ & $1.8 \mathrm{E}-4$ & 71 & 0.0468 & 3.0 & 0.120 & 6.5 & 0.043 & 2,200 & 704 & 0.003 & 2.1 & 22.1 & \pm 0.5 & $2,846.8$ & 0.01 & 16.5 & 0.7 & 4.0 & 0.8 & 56.5 & 291.7 & 519.5 & 893.4 & $12,938.3$ & 3.1 & 3.6 \\
\hline 1304-05.1 & $1.2 \mathrm{E}-3$ & 32 & 0.0505 & 3.4 & 0.081 & 15.8 & 0.516 & 1,514 & 434 & 0.003 & 3.8 & 21.9 & \pm 0.8 & $3,036.0$ & 0.05 & 10.5 & 1.3 & 4.6 & 0.9 & 63.4 & 299.5 & 523.4 & 878.7 & $10,098.3$ & 1.8 & 14.1 \\
\hline 1304-06.1 & $1.8 \mathrm{E}-3$ & 35 & 0.0673 & 4.0 & 0.130 & 10.1 & 2.634 & 773 & 219 & 0.004 & 2.9 & 22.3 & \pm 0.7 & $2,036.1$ & 2.41 & 8.1 & 6.8 & 6.9 & 1.5 & 54.6 & 204.1 & 348.7 & 587.7 & $10,051.5$ & 1.8 & 26.5 \\
\hline 1304-07.1 & $3.4 \mathrm{E}-4$ & 58 & 0.0499 & 3.3 & 0.150 & 17.3 & 0.436 & 1,596 & 830 & 0.003 & 2.3 & 22.3 & \pm 0.5 & $4,842.5$ & 0.07 & 24.7 & 3.6 & 12.3 & 1.9 & 122.2 & 530.0 & 863.9 & $1,416.9$ & $10,412.8$ & 2.7 & 0.9 \\
\hline 1304-09.1 & - & 100 & 0.0434 & 5.4 & 0.084 & 23.0 & -0.391 & 848 & 258 & 0.003 & 2.8 & 22.2 & \pm 0.6 & $1,948.7$ & 0.01 & 8.6 & 1.1 & 3.1 & 0.6 & 38.4 & 195.3 & 350.0 & 638.7 & $10,031.9$ & 2.7 & 0.7 \\
\hline $1304-10.1$ & $1.1 \mathrm{E}-3$ & 41 & 0.0446 & 4.3 & 0.044 & 14.8 & -0.239 & 1,000 & 190 & 0.003 & 2.3 & 21.9 & \pm 0.5 & $1,942.6$ & 0.01 & 5.7 & 0.4 & 1.9 & 0.4 & 29.3 & 178.5 & 363.5 & 664.1 & $12,441.0$ & 1.8 & 4.3 \\
\hline 1304-11.1 & - & 100 & 0.0494 & 3.3 & 0.073 & 9.2 & 0.365 & 1,508 & 357 & 0.004 & 2.1 & 22.9 & \pm 0.5 & $2,836.4$ & 0.12 & 8.4 & 0.9 & 3.6 & 0.7 & 49.3 & 272.3 & 509.2 & 922.9 & $11,912.6$ & 1.7 & 1.3 \\
\hline $1304-12.1$ & $6.1 \mathrm{E}-4$ & 45 & 0.0474 & 3.4 & 0.143 & 6.9 & 0.124 & 1,508 & 600 & 0.003 & 2.2 & 22.1 & \pm 0.5 & $3,314.0$ & 0.57 & 21.5 & 2.0 & 6.3 & 1.2 & 70.7 & 336.2 & 599.2 & $1,078.9$ & $9,877.9$ & 4.3 & 2.1 \\
\hline $1304-13.1$ & $1.3 \mathrm{E}-4$ & 100 & 0.0429 & 7.7 & 0.071 & 10.4 & -0.456 & 1,375 & 253 & 0.004 & 1.8 & 22.7 & \pm 0.4 & $2,077.5$ & 0.00 & 4.9 & 0.3 & 1.8 & 0.4 & 30.6 & 184.7 & 375.7 & 703.1 & $11,729.1$ & 1.4 & 0.7 \\
\hline 1304-14.1 & $1.1 \mathrm{E}-3$ & 35 & 0.0474 & 3.8 & 0.146 & 7.4 & 0.119 & 1,236 & 555 & 0.004 & 2.3 & 23.2 & \pm 0.5 & $4,220.2$ & 1.58 & 19.9 & 7.5 & 10.4 & 2.4 & 121.5 & 452.7 & 723.7 & $1,152.6$ & $9,560.4$ & 3.7 & 131.9 \\
\hline 1304-15.1 & - & - & 0.0453 & 3.4 & 0.108 & 7.9 & -0.152 & 1,612 & 554 & 0.004 & 2.2 & 22.6 & \pm 0.5 & $3,718.9$ & 0.03 & 16.9 & 2.2 & 6.9 & 1.4 & 82.3 & 385.4 & 663.7 & $1,134.8$ & $10,567.0$ & 3.0 & 0.9 \\
\hline $1304-16.1$ & - & - & 0.0478 & 4.3 & 0.066 & 12.5 & 0.166 & 966 & 267 & 0.003 & 2.5 & 21.2 & \pm 0.5 & $2,403.4$ & 0.01 & 8.6 & 1.2 & 4.5 & 0.9 & 54.1 & 243.4 & 433.4 & 722.0 & $10,819.7$ & 2.3 & 0.4 \\
\hline $1304-17.1$ & $3.9 \mathrm{E}-4$ & 50 & 0.0442 & 3.2 & 0.131 & 6.4 & -0.287 & 1,927 & 699 & 0.004 & 3.4 & 23.3 & \pm 0.8 & $3,528.1$ & 0.46 & 15.2 & 1.6 & 5.5 & 1.1 & 76.3 & 355.3 & 593.7 & 994.2 & $8,786.6$ & 2.0 & 8.1 \\
\hline $1304-18.1$ & 7.9E- -5 & 100 & 0.0447 & 2.9 & 0.088 & 17.6 & -0.234 & 2,184 & 595 & 0.004 & 2.2 & 23.8 & \pm 0.5 & $3,228.0$ & 0.02 & 8.4 & 0.6 & 3.5 & 0.6 & 51.8 & 314.4 & 601.2 & $1,051.5$ & $12,052.0$ & 1.7 & 0.8 \\
\hline 1304-19.1 & $-7.4 \mathrm{E}-4$ & 58 & 0.0449 & 5.2 & 0.117 & 11.2 & -0.203 & 765 & 262 & 0.003 & 2.0 & 22.1 & \pm 0.4 & $2,175.2$ & 0.02 & 9.7 & 1.7 & 5.7 & 1.1 & 52.9 & 227.3 & 402.8 & 701.5 & $10,646.5$ & 3.4 & 0.8 \\
\hline $1304-20.1$ & $2.6 \mathrm{E}-4$ & 71 & 0.0440 & 3.7 & 0.052 & 12.5 & -0.313 & 1,417 & 246 & 0.003 & 1.8 & 21.6 & \pm 0.4 & $1,467.8$ & 0.00 & 5.6 & 0.3 & 2.1 & 0.5 & 28.5 & 144.4 & 237.7 & 417.6 & $11,630.5$ & 1.7 & 0.7 \\
\hline \multicolumn{27}{|c|}{ Sample HJB-3 } \\
\hline HJB3-01.1 & $8.3 \mathrm{E}-5$ & 100 & 0.0468 & 6.8 & 0.165 & 5.2 & -0.099 & 647 & 359 & 0.01226 & 3.2 & 78.6 & \pm 3 & 746.4 & 0.46 & 32.3 & 1.2 & 2.7 & 1.4 & 24.2 & 73.4 & 115.5 & 216.0 & $11,160.7$ & 3.5 & 6.9 \\
\hline HJB3-02.1 & $-3.6 \mathrm{E}-4$ & 100 & 0.0509 & 6.9 & 0.086 & 15.6 & 0.253 & 85 & 32 & 0.02199 & 3.9 & 140 & \pm 5 & 237.6 & 0.01 & 11.3 & 0.1 & 0.2 & 0.1 & 3.8 & 18.6 & 44.2 & 101.9 & $9,779.9$ & 4.5 & 0.2 \\
\hline HJB3-03.1 & $1.6 \mathrm{E}-5$ & 58 & 0.1021 & 0.6 & 0.002 & 10.9 & 0.360 & 491 & 5 & 0.28364 & 1.6 & 1605 & \pm 26 & 1169.1 & 0.02 & 4.5 & 0.2 & 0.9 & 0.4 & 18.4 & 126.8 & 162.7 & 161.1 & $12,916.6$ & 4.7 & 14.7 \\
\hline HJB3-04.1 & $5.3 \mathrm{E}-5$ & 71 & 0.0815 & 1.5 & 0.199 & 2.7 & 0.409 & 140 & 95 & 0.19553 & 2.7 & 1147 & \pm 29 & 517.3 & 0.12 & 32.8 & 0.3 & 1.1 & 0.3 & 11.8 & 50.4 & 90.6 & 166.9 & $11,696.6$ & 9.7 & 1.0 \\
\hline HJB3-05.1 & $5.4 \mathrm{E}-4$ & 71 & 0.0390 & 6.6 & 0.209 & 8.6 & -1.092 & 216 & 127 & 0.01228 & 1.7 & 79.5 & \pm 1 & 893.9 & 0.01 & 24.5 & 0.8 & 2.8 & 1.4 & 26.8 & 93.0 & 146.1 & 247.3 & $9,819.2$ & 4.2 & 0.3 \\
\hline
\end{tabular}


Table 3. SHRIMP-RG U-Pb zircon data for samples analyzed in this report, Lane Mountain area-Continued

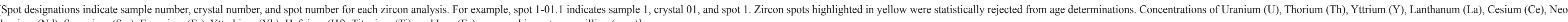
dymium (Nd), Samarium (Sm), Europium (Er), Ytterbium (Yb), Hafnium (Hf), Titanium (Ti), and Iron (Fe) measured in parts per million (ppm)]

\begin{tabular}{|c|c|c|c|c|c|c|c|c|c|c|c|c|c|c|c|c|c|c|c|c|c|c|c|c|c|c|}
\hline Spot & ${ }^{204} \mathrm{~Pb} / 206 \mathrm{~Pb}$ & $\pm \%$ & ${ }^{207} \mathrm{~Pb} / 200 \mathrm{~Pb}$ & $\pm \%$ & ${ }^{208 \mathrm{~Pb} / 206 \mathrm{~Pb}}$ & $\pm \%$ & $\begin{array}{c}\% \\
200 \mathrm{~Pb}_{\mathrm{c}}\end{array}$ & $\stackrel{\mathrm{ppm}}{\mathrm{U}}$ & $\begin{array}{c}\mathrm{ppm} \\
\mathrm{Th}\end{array}$ & $\begin{array}{c}\text { Total } \\
{ }_{200}^{200 \mathrm{~Pb}} / 238 \mathrm{U}\end{array}$ & $\pm \%$ & $\begin{array}{l}200 \mathrm{~Pb} / p^{33} \\
\text { Age (M }\end{array}$ & & $\begin{array}{c}Y \\
\text { (ppm) }\end{array}$ & $\begin{array}{c}\mathrm{La} \\
\text { (ppm) }\end{array}$ & Ce (ppm) & $\begin{array}{c}\mathrm{Nd} \\
(\mathrm{ppm})\end{array}$ & $\begin{array}{c}\mathrm{Sm} \\
(\mathrm{ppm})\end{array}$ & $\begin{array}{c}\text { Eu } \\
(\mathrm{ppm})\end{array}$ & Gd (ppm) & $\begin{array}{c}\text { Dy } \\
\text { (ppm) }\end{array}$ & $\begin{array}{c}\text { Er } \\
\text { (ppm) }\end{array}$ & $\begin{array}{c}\mathrm{Yb} \\
(\mathrm{ppm})\end{array}$ & $\begin{array}{c}\begin{array}{c}\mathrm{Hf} \\
(\mathrm{ppm})\end{array} \\
\text { (1) }\end{array}$ & $\begin{array}{c}\mathrm{Ti} \\
(\mathrm{ppm})\end{array}$ & $\begin{array}{c}\mathrm{Fe} \\
(\mathrm{ppm})\end{array}$ \\
\hline \multicolumn{27}{|c|}{ Sample HJB-3-Continued } \\
\hline HJB3-06.1 & $4.7 \mathrm{E}-4$ & 100 & 0.0435 & 8.5 & 0.264 & 10.1 & -0.496 & 111 & 89 & 0.01114 & 3.9 & 71.8 & \pm 3 & 951.3 & 0.03 & 16.2 & 1.3 & 2.3 & 1.6 & 24.4 & 89.8 & 155.6 & 255.0 & $7,313.3$ & 14.2 & 0.3 \\
\hline HJB3-07.1 & $5.5 \mathrm{E}-4$ & 100 & 0.0465 & 8.8 & 0.145 & 15.0 & -0.119 & 162 & 99 & 0.01125 & 1.8 & 72.2 & \pm 1 & 266.5 & 0.00 & 17.3 & 0.2 & 0.7 & 0.4 & 7.2 & 23.8 & 44.6 & 80.6 & $11,752.7$ & 4.1 & 1.3 \\
\hline HJB3-08.1 & - & 100 & 0.0486 & 14.5 & 0.215 & 18.8 & 0.168 & 38 & 27 & 0.00997 & 2.9 & 63.8 & \pm 2 & 406.4 & 0.01 & 8.8 & 0.9 & 2.2 & 1.3 & 17.0 & 44.8 & 61.2 & 95.0 & $8,623.2$ & 9.9 & 3.4 \\
\hline HJB3-09.1 & $-1.3 \mathrm{E}-3$ & 71 & 0.0427 & 10.4 & 0.445 & 9.7 & -0.602 & 91 & 136 & 0.01137 & 6.0 & 73.3 & \pm 4 & 887.1 & 0.04 & 33.4 & 2.5 & 5.3 & 3.4 & 50.7 & 113.2 & 114.1 & 128.0 & $7,935.0$ & 22.2 & 0.5 \\
\hline HJB3-10.1 & - & 100 & 0.0499 & 9.1 & 0.219 & 13.6 & 0.318 & 92 & 65 & 0.01062 & 1.8 & 67.9 & \pm 1 & 833.3 & 3.23 & 27.7 & 3.0 & 3.6 & 2.7 & 32.6 & 88.4 & 136.0 & 228.1 & $7,693.1$ & 9.3 & 3.9 \\
\hline HJB3-11.1 & 3.6E-4 & 100 & 0.0428 & 14.1 & 0.144 & 11.7 & -0.621 & 152 & 86 & 0.01295 & 1.8 & 83.5 & \pm 2 & 320.3 & 0.01 & 13.4 & 0.4 & 1.0 & 0.5 & 8.8 & 29.3 & 51.8 & 98.4 & $9,917.9$ & 4.8 & 0.3 \\
\hline HJB3-12.1 & - & 100 & 0.0468 & 4.7 & 0.254 & 6.1 & -0.258 & 195 & 172 & 0.02200 & 2.5 & 141 & \pm 4 & $1,545.9$ & 0.02 & 32.7 & 0.9 & 2.8 & 0.7 & 28.8 & 148.8 & 291.7 & 551.9 & $12,392.5$ & 8.3 & 8.0 \\
\hline HJB3-13.1 & $2.1 \mathrm{E}-4$ & 100 & 0.0712 & 4.4 & 0.062 & 13.7 & 2.959 & 220 & 70 & 0.01365 & 3.1 & 84.8 & \pm 3 & 262.9 & 0.01 & 11.4 & 0.1 & 0.4 & 0.3 & 5.3 & 20.2 & 40.5 & 91.9 & $8,321.5$ & 1.5 & 1.6 \\
\hline HJB3-14.1 & 4.1E-4 & 100 & 0.0472 & 7.6 & 0.085 & 16.8 & -0.207 & 70 & 27 & 0.02156 & 1.9 & 138 & \pm 3 & 261.9 & 0.05 & 10.6 & 0.1 & 0.5 & 0.1 & 3.8 & 20.0 & 46.9 & 107.2 & $9,541.4$ & 6.9 & 3.6 \\
\hline HJB3-15.1 & - & 100 & 0.0398 & 15.4 & 0.161 & 21.2 & -0.961 & 38 & 23 & 0.01088 & 2.8 & 70.4 & \pm 2 & 480.4 & 0.49 & 14.1 & 1.1 & 2.1 & 1.5 & 18.8 & 56.6 & 75.0 & 103.8 & $9,808.1$ & 49.0 & 8.1 \\
\hline HJB3-16.1 & $5.0 \mathrm{E}-3$ & 71 & 0.0469 & 18.5 & 0.323 & 20.0 & -0.062 & 28 & 25 & 0.01028 & 8.4 & 66.0 & \pm 6 & 345.3 & 0.01 & 12.1 & 1.2 & 2.3 & 1.3 & 17.6 & 42.6 & 49.3 & 72.0 & $9,194.8$ & 8.7 & 0.1 \\
\hline HJB3-17.1 & - & 100 & 0.0477 & 3.6 & 0.152 & 6.1 & 0.020 & 614 & 284 & 0.01149 & 4.7 & 73.6 & \pm 3 & 415.9 & 0.03 & 7.8 & 0.1 & 0.2 & 0.3 & 4.0 & 29.9 & 57.2 & 134.0 & $13,575.2$ & 2.2 & 4.7 \\
\hline HJB3-18.1 & $1.0 \mathrm{E}-2$ & 22 & 0.1382 & 5.0 & 0.491 & 7.8 & 11.451 & 136 & 172 & 0.01224 & 4.9 & 69.5 & \pm 3 & $1,098.8$ & 0.61 & 41.5 & 2.1 & 3.8 & 2.6 & 44.9 & 125.9 & 148.5 & 208.4 & $8,780.5$ & 18.2 & 450.9 \\
\hline HJB3-19.1 & - & - & 0.0734 & 2.2 & 0.247 & 3.5 & 2.298 & 182 & 59 & 0.06625 & 6.1 & 404 & \pm 24 & 490.5 & 0.03 & 12.0 & 0.9 & 2.2 & 0.5 & 14.3 & 42.7 & 80.0 & 152.6 & $9,515.4$ & 4.5 & 3.1 \\
\hline HJB3-20.1 & $-8.4 \mathrm{E}-5$ & 100 & 0.0464 & 6.2 & 0.137 & 5.8 & -0.200 & 414 & 197 & 0.01553 & 3.3 & 99.5 & \pm 3 & $1,249.2$ & 0.11 & 22.6 & 1.9 & 3.8 & 1.8 & 34.3 & 115.2 & 200.0 & 358.8 & $8,987.1$ & 4.2 & 1.7 \\
\hline
\end{tabular}




\section{Geochronologic, Isotopic, and Geochemical Data from Igneous Rocks in the Lane Mountain Area, California}

Table 4. Rubidium-strontium isotopic data for the eight samples analyzed for this report.

$\left[\mathrm{Sr}_{\mathrm{i}}\right.$ is the calculated initial ${ }^{87} \mathrm{Sr} r{ }^{86} \mathrm{Sr}$ ratio; Ma, Mega-annum; concentrations of rubidium $(\mathrm{Rb})$ and strontium are measured in parts per million (ppm)]

\begin{tabular}{ccccccc}
\hline Sample & $\begin{array}{c}\text { Age } \\
(\mathbf{M a})\end{array}$ & $\begin{array}{c}\mathbf{R b} \\
(\mathbf{p p m})\end{array}$ & $\begin{array}{c}\mathbf{S r} \\
(\mathbf{p p m})\end{array}$ & ${ }^{87} \mathbf{S r} /{ }^{66} \mathbf{S r}$ & ${ }^{87} \mathbf{R b} /{ }^{66} \mathbf{S r}$ & $\mathbf{S r}_{\mathbf{i}}$ \\
\hline $14-L M-1$ & 151 & 110 & 370 & 0.70772 & 0.8601577 & 0.70590 \\
$14-$ LM-43 & 253 & 65 & 634 & 0.70501 & 0.2965487 & 0.70396 \\
$14-L M-64$ & 82 & 88.5 & 671 & 0.70921 & 0.3816552 & 0.70877 \\
$14-L M-154$ & 146 & 16.8 & 485 & 0.70573 & 0.1002005 & 0.70553 \\
$14-L M-490$ & 149 & 56 & 480 & 0.70581 & 0.3374837 & 0.70511 \\
$15-L M-1076$ & 85 & 116 & 541 & 0.70883 & 0.6204331 & 0.70809 \\
$16-L M-1301$ & 80 & 99.9 & 645 & 0.71026 & 0.4482299 & 0.70976 \\
HJB-3 & 72 & 91.7 & 604 & 0.71029 & 0.4393683 & 0.70985 \\
\hline
\end{tabular}

Table 5. WDXRF (Wavelength dispersive X-ray fluorescence) geochemical analyses of samples studied for this report.

[Numerical values are in weight percent; LOI, loss on ignition]

Samples

\begin{tabular}{|c|c|c|c|c|c|c|c|c|c|c|}
\hline Element (Oxide) & 14-LM-1 & 14-LM-43 & 14-LM-64 & 14-LM-154 & 14-LM-490 & 15-LM-1076 & 15-LM-1124 & 16-LM-1301 & 16-LM-1304 & HJB-3 \\
\hline $\mathrm{SiO}_{2}$ & 66.8 & 56.9 & 69.9 & 49.5 & 61.1 & 68.4 & 70.2 & 68.6 & 74 & 69.1 \\
\hline $\mathrm{TiO}_{2}$ & 0.56 & 0.94 & 0.36 & 1.05 & 0.81 & 0.58 & 0.42 & 0.54 & 0.07 & 0.46 \\
\hline $\mathrm{Al}_{2} \mathrm{O}_{3}$ & 15.7 & 16.7 & 16.3 & 18.7 & 17.1 & 15.4 & 15.3 & 15.7 & 12.9 & 15.6 \\
\hline $\mathrm{MgO}$ & 1.33 & 3.36 & 0.72 & 6.98 & 2.41 & 1.25 & 0.71 & 0.98 & 0.12 & 0.87 \\
\hline $\mathrm{Fe}_{2} \mathrm{O}_{3}$ & 3.92 & 8.16 & 2.04 & 7.42 & 6.49 & 3.34 & 2.39 & 3.13 & 1.64 & 2.74 \\
\hline $\mathrm{MnO}$ & 0.06 & 0.14 & 0.01 & 0.11 & 0.12 & 0.05 & 0.03 & 0.03 & 0.03 & 0.03 \\
\hline $\mathrm{CaO}$ & 3.3 & 6.83 & 2.97 & 11.9 & 5.65 & 3.65 & 2.72 & 3.22 & 1.07 & 2.71 \\
\hline $\mathrm{K}_{2} \mathrm{O}$ & 3.42 & 2.21 & 3.45 & 0.6 & 2.03 & 3.29 & 3.58 & 3.29 & 4.89 & 3.45 \\
\hline $\mathrm{Na}_{2} \mathrm{O}$ & 3.72 & 3.46 & 4.11 & 2.54 & 4.04 & 3.48 & 3.79 & 3.9 & 3.38 & 3.88 \\
\hline $\mathrm{P}_{2} \mathrm{O}_{5}$ & 0.16 & 0.3 & 0.11 & 0.22 & 0.24 & 0.14 & 0.12 & 0.18 & 0.02 & 0.14 \\
\hline $\mathrm{Cr}_{2} \mathrm{O}_{3}$ & $<0.01$ & 0.01 & $<0.01$ & 0.05 & 0.05 & $<0.01$ & 0.01 & $<0.01$ & $<0.01$ & $<0.01$ \\
\hline LOI & 0.89 & 0.68 & 0.69 & 1.94 & 0.76 & 0.67 & 0.79 & 0.54 & 1.08 & 1.13 \\
\hline Total & 99.86 & 99.69 & 100.66 & 101.01 & 100.80 & 100.25 & 100.06 & 100.11 & 99.2 & 100.11 \\
\hline \multicolumn{11}{|c|}{ Normalized values (volatile-free) } \\
\hline $\mathrm{SiO}_{2}$ & 67.5 & 57.47 & 69.92 & 49.96 & 61.08 & 68.69 & 70.72 & 68.9 & 75.42 & 69.81 \\
\hline $\mathrm{TiO}_{2}$ & 0.57 & 0.95 & 0.36 & 1.06 & 0.81 & 0.58 & 0.42 & 0.54 & 0.07 & 0.46 \\
\hline $\mathrm{Al}_{2} \mathrm{O}_{3}$ & 15.86 & 16.87 & 16.3 & 18.88 & 17.09 & 15.46 & 15.41 & 15.77 & 13.15 & 15.76 \\
\hline $\mathrm{MgO}$ & 1.34 & 3.39 & 0.72 & 7.05 & 2.41 & 1.26 & 0.72 & 0.98 & 0.12 & 0.88 \\
\hline $\mathrm{Fe}_{2} \mathrm{O}_{3}$ & 3.96 & 8.24 & 2.04 & 7.49 & 6.49 & 3.35 & 2.41 & 3.14 & 1.67 & 2.77 \\
\hline $\mathrm{MnO}$ & 0.06 & 0.14 & 0.01 & 0.11 & 0.12 & 0.05 & 0.03 & 0.03 & 0.03 & 0.03 \\
\hline $\mathrm{CaO}$ & 3.33 & 6.9 & 2.97 & 12.01 & 5.65 & 3.67 & 2.74 & 3.23 & 1.09 & 2.74 \\
\hline $\mathrm{K}_{2} \mathrm{O}$ & 3.46 & 2.23 & 3.45 & 0.61 & 2.03 & 3.3 & 3.61 & 3.3 & 4.98 & 3.49 \\
\hline $\mathrm{Na}_{2} \mathrm{O}$ & 3.76 & 3.49 & 4.11 & 2.56 & 4.04 & 3.49 & 3.82 & 3.92 & 3.44 & 3.92 \\
\hline $\mathrm{P}_{2} \mathrm{O}_{5}$ & 0.16 & 0.3 & 0.11 & 0.22 & 0.24 & 0.14 & 0.12 & 0.18 & 0.02 & 0.14 \\
\hline $\mathrm{Cr}_{2} \mathrm{O}_{3}$ & $<0.01$ & 0.01 & $<0.01$ & 0.05 & 0.05 & $<0.01$ & 0.01 & $<0.01$ & $<0.01$ & $<0.01$ \\
\hline Total & 100 & 99.99 & 99.99 & 100 & 100.01 & 99.99 & 100.01 & 99.99 & 99.99 & 100 \\
\hline
\end{tabular}


Table 6. ICP-AES-MS (Inductively coupled plasma atomic emission spectroscopy-mass spectrometry) geochemical analyses of samples studied for this report.

[Numerical values are in weight percent (\%) or parts per million (ppm), as indicated. Si, silicon; Ti, titanium, $\mathrm{Al}$, aluminum; $\mathrm{Mg}$, magnesium; Fe, iron; $\mathrm{Mn}$, manganese, Ca, calcium; K, potassium; P, phosphorus; S, sulfur; Li, lithium; Be, beryllium; B, boron; Sc, scandium; V, vanadium; Cr, chromium; Co, cobalt; Ni, nickel; $\mathrm{Cu}$, copper; $\mathrm{Zn}$, zinc; Ga, gallium; Ge, germanium; As, arsenic; Rb, rubidium; Sr, strontium; Y, yttrium; Zr, zirconium; Nb, niobium; Mo, molybdenum; Ag, silver; Cd, cadmium; In, indium; Sn, tin; Sb, antimony; Cs, cesium; Ba, barium; Hf, hafnium; Ta, tantalum; W, tungsten; Tl, thallium; Pb, lead; Bi, bismuth; Th, thorium; U, uranium; La, lanthanum; Ce, cerium; Pr, praseodymium; Nd, neodymium; Sm, samarium; Eu, europium; Gd, gadolinium; Tb, terbium; Dy, dysprosium; Ho, holmium; Er, erbium; Tm, thulium; Yb, ytterbium; Lu, lutetium]

\section{Samples}

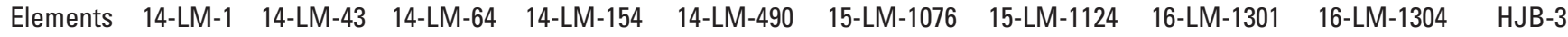

\begin{tabular}{|c|c|c|c|c|c|c|c|c|c|c|}
\hline \multicolumn{11}{|c|}{$\%$} \\
\hline $\mathrm{Si}$ & - & - & - & - & - & - & - & $>30$ & $>30$ & - \\
\hline $\mathrm{Ti}$ & 0.32 & 0.54 & 0.19 & 0.58 & 0.46 & 0.33 & 0.24 & 0.3 & 0.04 & 0.26 \\
\hline $\mathrm{Mg}$ & 0.77 & 1.94 & 0.41 & 3.93 & 1.32 & 0.74 & 0.42 & 0.57 & 0.05 & 0.49 \\
\hline $\mathrm{Fe}$ & 2.59 & 5.5 & 1.34 & 4.84 & 4.21 & 2.21 & 1.62 & 2.07 & 1.08 & 1.98 \\
\hline $\mathrm{Ca}$ & 2.45 & 4.88 & 2.2 & 8.1 & 3.85 & 2.4 & 1.8 & 2.4 & 0.8 & 1.9 \\
\hline $\mathrm{K}$ & 2.82 & 1.98 & 2.8 & 0.59 & 1.73 & 2.8 & 3 & 2.9 & 4.2 & 2.9 \\
\hline $\mathrm{P}$ & 0.05 & 0.15 & 0.04 & 0.09 & 0.1 & 0.06 & 0.05 & 0.07 & $<0.01$ & 0.06 \\
\hline $\mathrm{S}$ & - & - & - & - & - & - & - & 0.01 & $<0.01$ & - \\
\hline \multicolumn{11}{|c|}{ ppm } \\
\hline $\mathrm{Sc}$ & 9 & 21 & $<5$ & 31 & 15 & 5 & $<5$ & $<5$ & $<5$ & $<5$ \\
\hline $\mathrm{V}$ & 70 & 229 & 32 & 163 & 126 & 58 & 32 & 48 & 9 & 39 \\
\hline $\mathrm{Cr}$ & 10 & 10 & $<10$ & 300 & 10 & 10 & 10 & $<10$ & $<10$ & $<10$ \\
\hline Co & 8.1 & 22.5 & 3.5 & 30.5 & 14.1 & 6.8 & 3.2 & 5 & $<0.5$ & 3.8 \\
\hline $\mathrm{Ni}$ & $<5$ & $<5$ & $<5$ & 74 & 18 & $<5$ & $<5$ & 11 & 8 & $<5$ \\
\hline $\mathrm{Cu}$ & 6 & 110 & $<5$ & 56 & 39 & $<5$ & 13 & 6 & 6 & 7 \\
\hline $\mathrm{Zn}$ & 55 & 79 & 50 & 52 & 70 & 57 & 60 & 61 & 57 & 70 \\
\hline $\mathrm{Ga}$ & 18 & 19 & 22 & 17 & 19 & 22 & 23 & 23 & 23 & 21 \\
\hline $\mathrm{Nb}$ & 13 & 13 & 6 & 5 & 10 & 11 & 11 & 10 & 22 & 10 \\
\hline Mo & 2 & 2 & $<2$ & $<2$ & $<2$ & $<2$ & $<2$ & $<2$ & 4 & $<2$ \\
\hline $\mathrm{Ag}$ & $<1$ & $<1$ & $<1$ & $<1$ & $<1$ & $<1$ & $<1$ & $<1$ & $<1$ & $<1$ \\
\hline $\mathrm{Cd}$ & $<0.2$ & $<0.2$ & $<0.2$ & $<0.2$ & $<0.2$ & $<0.2$ & $<0.2$ & $<0.2$ & $<0.2$ & $<0.2$ \\
\hline In & $<0.2$ & $<0.2$ & $<0.2$ & $<0.2$ & $<0.2$ & $<0.2$ & $<0.2$ & $<0.2$ & $<0.2$ & $<0.2$ \\
\hline $\mathrm{Sn}$ & 2 & 1 & $<1$ & 1 & 2 & 2 & 2 & 1 & 6 & 2 \\
\hline $\mathrm{Sb}$ & 0.4 & 0.6 & 0.2 & 0.3 & 0.2 & 0.2 & 0.2 & $<0.1$ & 0.9 & 0.4 \\
\hline
\end{tabular}


Table 6. ICP-AES-MS (Inductively coupled plasma atomic emission spectroscopy-mass spectrometry) geochemical analyses of samples studied for this report.-Continued

[Numerical values are in weight percent (\%) or parts per million (ppm), as indicated. Si, silicon; Ti, titanium, Al, aluminum; $\mathrm{Mg}$, magnesium; Fe, iron; $\mathrm{Mn}$, manganese, Ca, calcium; K, potassium; P, phosphorus; S, sulfur; Li, lithium; Be, beryllium; B, boron; Sc, scandium; V, vanadium; Cr, chromium; Co, cobalt; Ni, nickel; $\mathrm{Cu}$, copper; Zn, zinc; Ga, gallium; Ge, germanium; As, arsenic; Rb, rubidium; Sr, strontium; Y, yttrium; Zr, zirconium; Nb, niobium; Mo, molybdenum; Ag, silver; Cd, cadmium; In, indium; Sn, tin; Sb, antimony; Cs, cesium; Ba, barium; Hf, hafnium; Ta, tantalum; W, tungsten; Tl, thallium; Pb, lead; Bi, bismuth; Th, thorium; U, uranium; La, lanthanum; Ce, cerium; Pr, praseodymium; Nd, neodymium; Sm, samarium; Eu, europium; Gd, gadolinium; Tb, terbium; Dy, dysprosium; Ho, holmium; Er, erbium; Tm, thulium; Yb, ytterbium; Lu, lutetium]

\begin{tabular}{ccccccccccc}
\hline Elements & 14-LM-1 & 14-LM-43 & 14-LM-64 & 14-LM-154 & 14-LM-490 & 15-LM-1076 & 15-LM-1124 & 16-LM-1301 & 16-LM-1304 & HJB-3 \\
\hline & & & \multicolumn{7}{c}{ 16 } & \multicolumn{7}{c}{ ppm-Continued } & & & & & \\
\hline $\mathrm{Cs}$ & 3.3 & 1.4 & 1 & 0.6 & 1.7 & 2.8 & 1.2 & 2.5 & 6.9 & 2.5 \\
$\mathrm{Ba}$ & 1010 & 613 & 726 & 276 & 782 & 854 & 1280 & 1114 & 642 & 1091 \\
$\mathrm{Hf}$ & 6 & 4 & 3 & 2 & 5 & 4 & 5 & 5 & 5 & 5 \\
$\mathrm{Ta}$ & 0.9 & 0.7 & $<0.5$ & $<0.5$ & 0.5 & 0.8 & 0.7 & 0.6 & 1.8 & $<0.5$ \\
$\mathrm{~W}$ & 2 & 2 & 1 & $<1$ & $<1$ & $<1$ & $<1$ & $<1$ & 3 & $<1$ \\
$\mathrm{Tl}$ & $<0.5$ & $<0.5$ & $<0.5$ & $<0.5$ & $<0.5$ & $<0.5$ & $<0.5$ & $<0.5$ & 1 & $<0.5$ \\
$\mathrm{~Pb}$ & 11 & 5 & 17 & 5 & 10 & 15 & 17 & 16 & 26 & 17 \\
$\mathrm{Bi}$ & $<0.1$ & $<0.1$ & $<0.1$ & $<0.1$ & $<0.1$ & $<0.1$ & $<0.1$ & $<0.1$ & $<0.1$ & $<0.1$ \\
$\mathrm{Th}$ & 10.4 & 5.2 & 8.1 & 1.1 & 4.2 & 10.3 & 11.2 & 10.3 & 16.5 & 11 \\
$\mathrm{U}$ & 2.85 & 1.95 & 2.9 & 0.39 & 1.66 & 2.54 & 2.67 & 2.25 & 5.11 & 2.57 \\
$\mathrm{La}$ & 38.4 & 21 & 25.1 & 10.7 & 23.6 & 30.2 & 42.2 & 41.7 & 27.2 & 39.4 \\
$\mathrm{Ce}$ & 73.5 & 44.9 & 37.6 & 24.4 & 47.2 & 55.1 & 78.2 & 74.1 & 49.7 & 74.5 \\
$\mathrm{Pr}$ & 8.31 & 5.69 & 3.82 & 3.34 & 5.77 & 6.25 & 8.91 & 8.32 & 5.94 & 8.79 \\
$\mathrm{Nd}$ & 28.8 & 23.4 & 12.9 & 14.5 & 23.5 & 22.3 & 31.3 & 30.1 & 22.1 & 29 \\
$\mathrm{Sm}$ & 5.2 & 4.9 & 2 & 3.4 & 4.7 & 4 & 4.8 & 4.9 & 5.4 & 5.1 \\
$\mathrm{Eu}$ & 1.11 & 1.17 & 0.6 & 1.2 & 1.41 & 0.93 & 1.1 & 1.26 & 0.79 & 1.22 \\
$\mathrm{Gd}$ & 4.6 & 4.78 & 1.52 & 3.56 & 4.57 & 3.04 & 3.19 & 3.41 & 5.33 & 3.58 \\
$\mathrm{~Tb}$ & 0.69 & 0.7 & 0.19 & 0.53 & 0.7 & 0.41 & 0.39 & 0.43 & 0.91 & 0.47 \\
$\mathrm{Dy}$ & 4.09 & 4.18 & 0.98 & 3.17 & 4.05 & 2.06 & 1.88 & 2.1 & 5.64 & 2.09 \\
$\mathrm{Ho}$ & 0.84 & 0.88 & 0.16 & 0.65 & 0.86 & 0.37 & 0.33 & 0.31 & 1.02 & 0.33 \\
$\mathrm{Er}$ & 2.46 & 2.51 & 0.46 & 1.84 & 2.48 & 0.99 & 0.85 & 0.91 & 3.06 & 0.9 \\
$\mathrm{Tm}$ & 0.38 & 0.37 & 0.06 & 0.26 & 0.38 & 0.14 & 0.12 & 0.13 & 0.49 & 0.12 \\
$\mathrm{Yb}$ & 2.5 & 2.3 & 0.4 & 1.6 & 2.6 & 0.9 & 0.7 & 0.8 & 3 & 0.7 \\
$\mathrm{Lu}$ & 0.38 & 0.37 & 0.07 & 0.23 & 0.38 & 0.13 & 0.11 & 0.12 & 0.5 & 0.13 \\
\hline
\end{tabular}


Menlo Park Publishing Service Center, California Manuscript approved for publication June 12, 2019 Edited by Phil Frederick

Layout by Kimber Petersen 
